\title{
UNIDADES DE PAISAGEM: A CRIAÇÃO DE UM MÉTODO PARA A ANÁLISE DO TERRITÓRIO DE SUZANO
}

LANDSCAPE UNITS: THE CREATION OF A METHOD TO ANALYZE SUZANO TERRITORY

\author{
Michele de Sá Vieira* \\ Silvio Soares Macedo**
}

\begin{abstract}
RESUMO
Este artigo trata da criação, bem como da aplicação de um método de avaliação para o desenvolvimento de reflexões vinculadas às questões urbanísticas, paisagísticas e ambientais do território de Suzano. Para tanto, o município foi dividido em 10 unidades de paisagem, utilizando-se da concentração significativa de determinadas características do território ao longo da extensão territorial, tais como o relevo e a densidade dos loteamentos ocupados, além da similaridade e uniformidade com relação ao uso e ocupação do solo (mata, vegetação de várzea, chácara, área urbanizada, indústria) como critérios para a subdivisão das unidades. Estas foram analisadas pelo viés de suas características, conflitos, previsão com relação aos cenários futuros possíveis, além do levantamento das principais ações públicas executadas entre os anos de 2005 e 2011 . Para tanto, compreende-se por conflito uma situação indesejável, ocasionada pelas formas de ocupação e apropriação dos recursos socioeconômicos e ambientais de um território, resultando em problemas sociais e/ou ambientais nesse espaço. Como cenário entende-se a possibilidade de futuras ações - positivas ou negativas - com relação a um determinado aspecto acontecerem ou não, podendo ser este representado pela construção de um parque, ampliação das matas nativas existentes, limpeza dos corpos d'água, ou através da consolidação das ocupações irregulares, do depósito de resíduos em lugares inadequados.
\end{abstract}

Palavras-chave: Unidades de Paisagem. Conflitos. Potencialidades. Características ambientais. Políticas públicas.

\section{ABSTRACT}

This article deals with the creation as well as the application of a method of evaluation for development discussions linked to urban, landscape and environmental questions regarding Suzano territory. Therefore, the municipality was divided into 10 units of land, using the significant concentration of certain features of the land throughout the territorial extension, such as relieve and the density of occupied allotments, besides the similarity and uniformity regarding the use and occupation of soil (wood, flood plain vegetation,

* Graduou-se pela Pontifícia Universidade Católica de Campinas (PUC-Campinas). Mestre em Arquitetura e Urbanismo pela Faculdade de Arquitetura e Urbanismo da Universidade de São Paulo (FAUUSP). Chefe da Divisão de Projetos Especiais na Secretaria Municipal de Planejamento Urbano da Prefeitura de São José dos Campos. Ex-secretária Municipal de Meio Ambiente da Prefeitura de Suzano. Professora da Universidade de Mogi das Cruzes e da Universidade Paulista.

savieiramichele@gmail.com.br

** Arquiteto pela Faculdade de Arquitetura e Urbanismo da Universidade de São Paulo. Professor titular de Paisagismo da Faculdade de Arquitetura e Urbanismo da Universidade de São Paulo (FAUUSP). Faculdade de Arquitetura e Urbanismo da Universidade de São Paulo - Departamento de Projetos ssmduck@usp.br 
farmstead, urbanized area, industry and so on), as the criteria in how to subdivide the units. These were analyzed by means of their characteristics, conflicts and their forecast based on possible future scenarios, in addition to the primary public projects completed between the years 2005 through 2011 . It is recognized because of the existing conflict to be an undesirable situation brought about by the methods of occupation and appropriation of the socioeconomic and environmental resources of a territory, resulting in social and/or environmental problems on this piece of land. As an understood scenario is the possibility of future positive or negative actions regarding certain determined aspects happening or not, being able to be this representative through the construction of a park, enlargement of already existing native parks, the cleaning of bodies of water, or through the consolidation of illegal occupations, waste deposits in inappropriate places and others.

Keywords: Landscape units. Conflict. Potential. Environmental characteristics. Public policies.

\section{SUZANO: UMA APROXIMAÇÃO PRÁTICA DO TERRITÓRIO}

objetivo deste artigo é apropriar-se do município de Suzano, vizinho às serras do Itapety e do Mar - e cortado por ampla área de várzea -, através do conhecimento do seu ambiente, da sua paisagem e dos processos de ocupação, relatando seus conflitos, os benefícios que o território ainda guarda, como as matas e a rede hídrica, que possuem papéis estruturantes em sua formação.

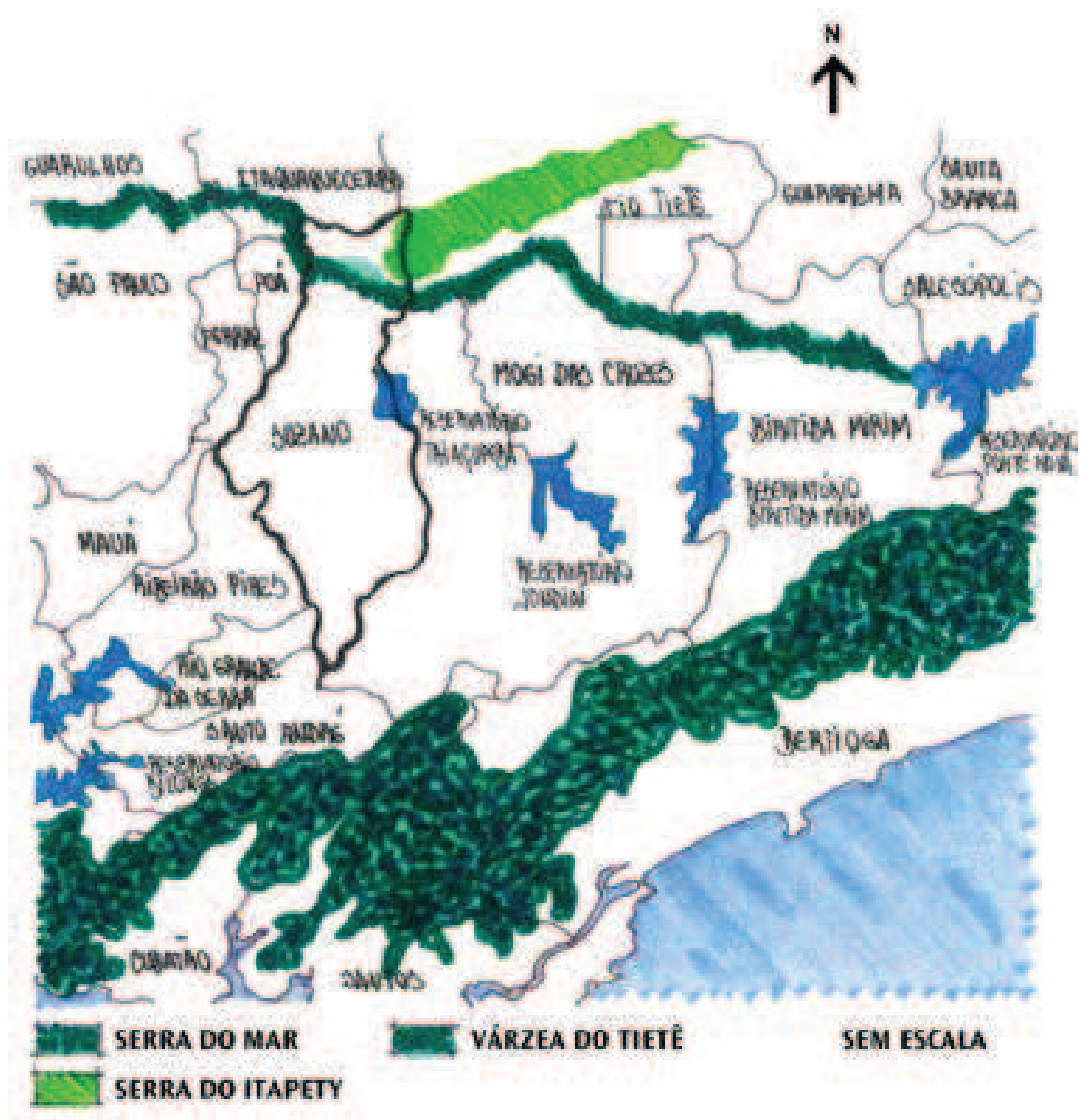

Figura 1 Mapa que aponta as potencialidades ambientais existentes no território de Suzano bem como no seu entorno.

Desenho: Michele de Sá Vieira - 2011.

Fonte: Mapa da SOS Mata Atlântica - 2008. Mapa dos Mananciais da Região Metropolitana de São Paulo (RMSP) - 2007. Mapa que demonstra as Áreas de Interesse Ambiental Especial da Secretaria Estadual de Meio Ambiente - 2000. 
Seu território é um mosaico em transformação, composto por várzeas, áreas urbanizadas, agricultura, águas, fragmentos de mata nativa e florestas de eucalipto.

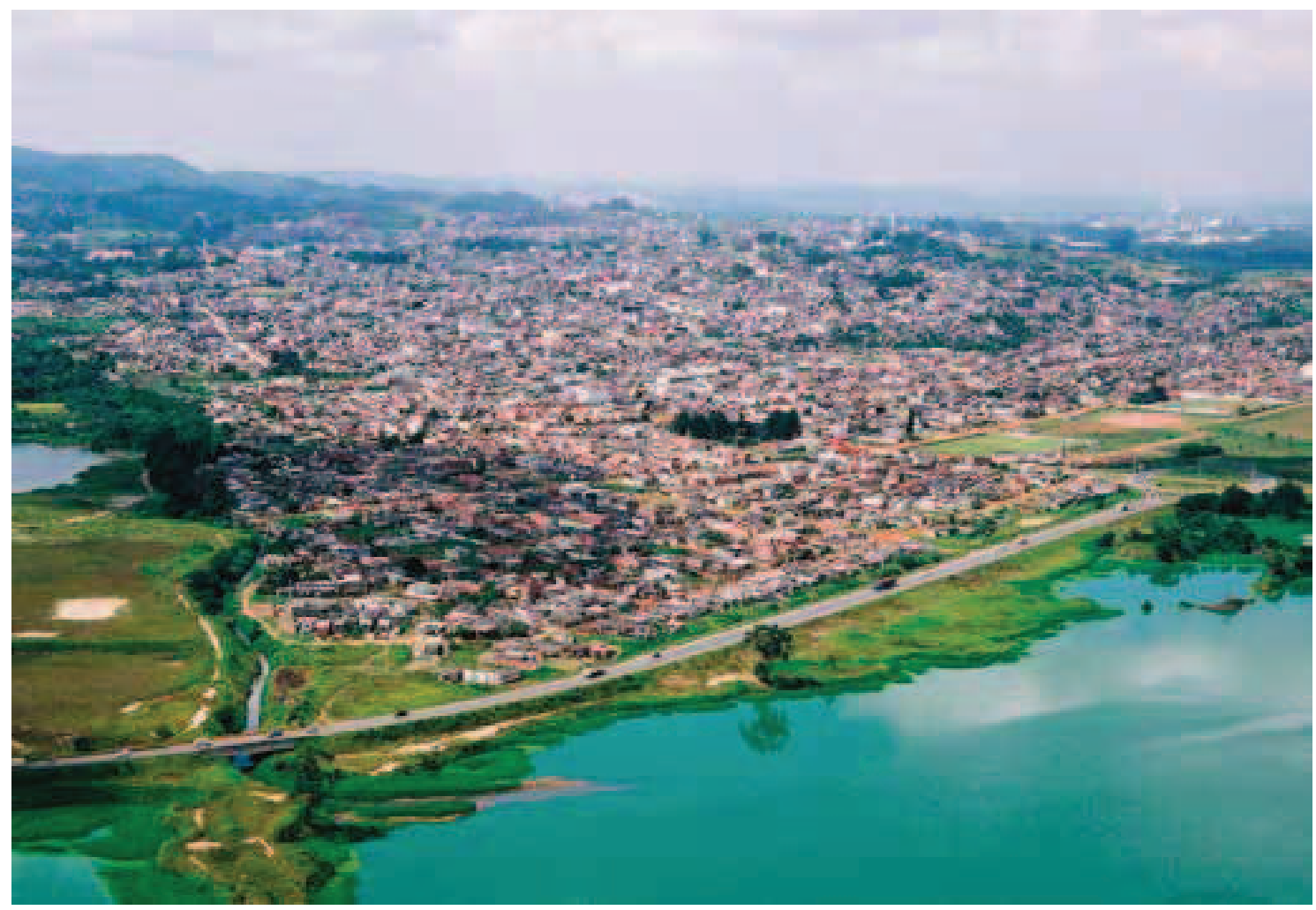

Figura 2 Distrito de Boa Vista - Loteamento Miguel Badra.

Fonte: Prefeitura Municipal de Suzano (PMS) - 2008.

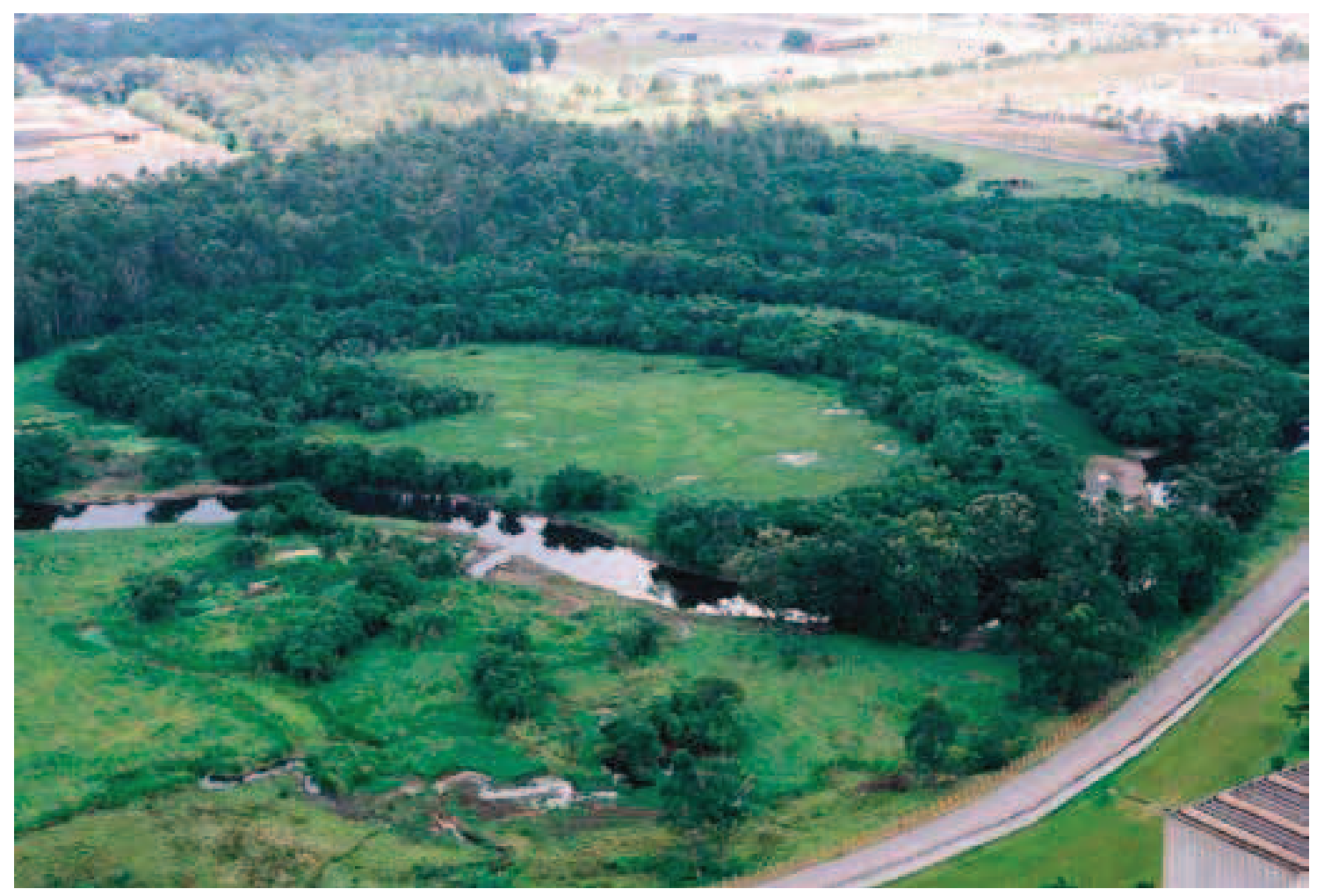

Figura 3 Distrito de Boa Vista e Central - Área de Proteção Ambiental (APA) do rio Tietê.

Fonte: PMS - 2008. 


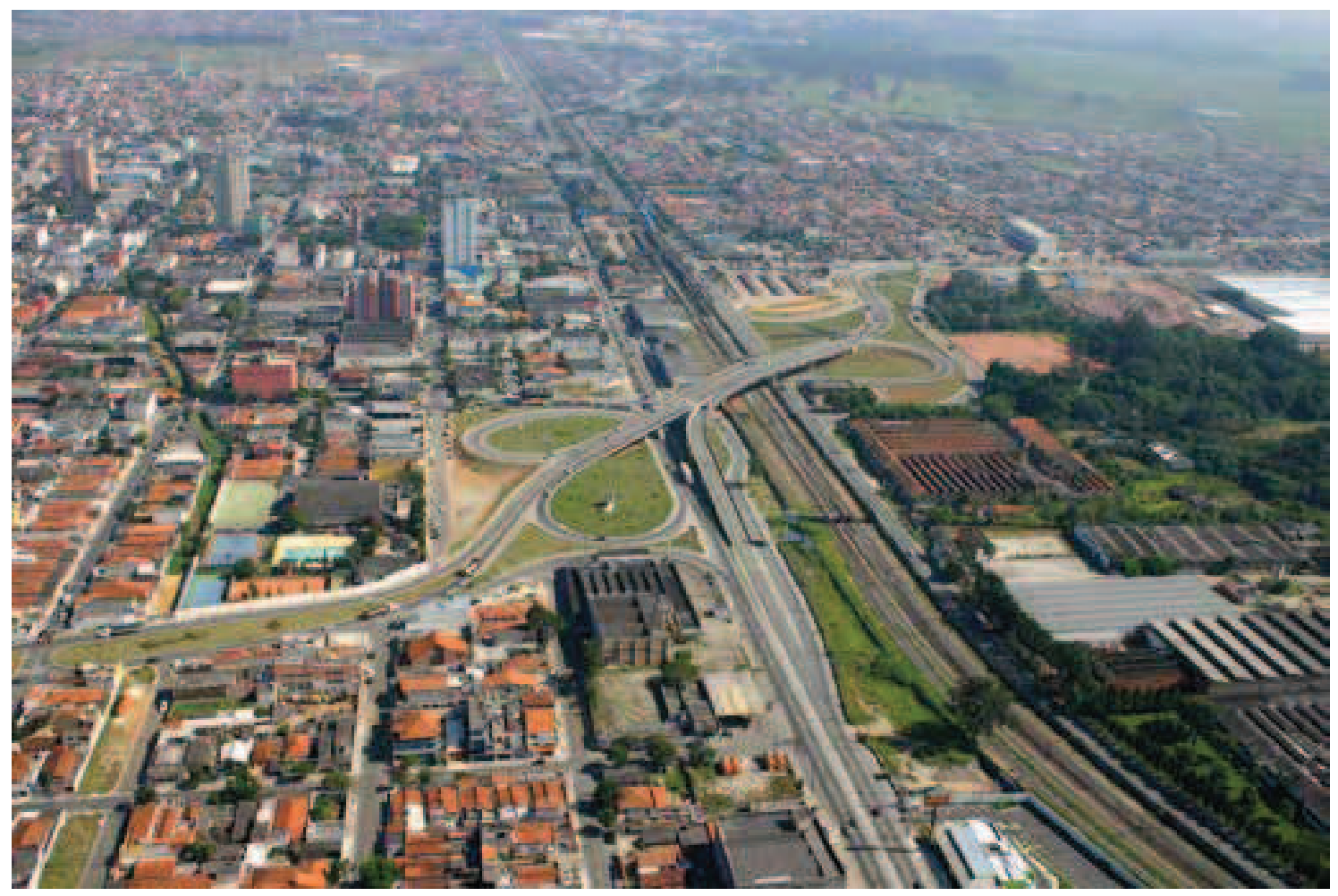

Figura 4 Distrito Central - Loteamento Vila Amorim.

Fonte: PMS - 2008.

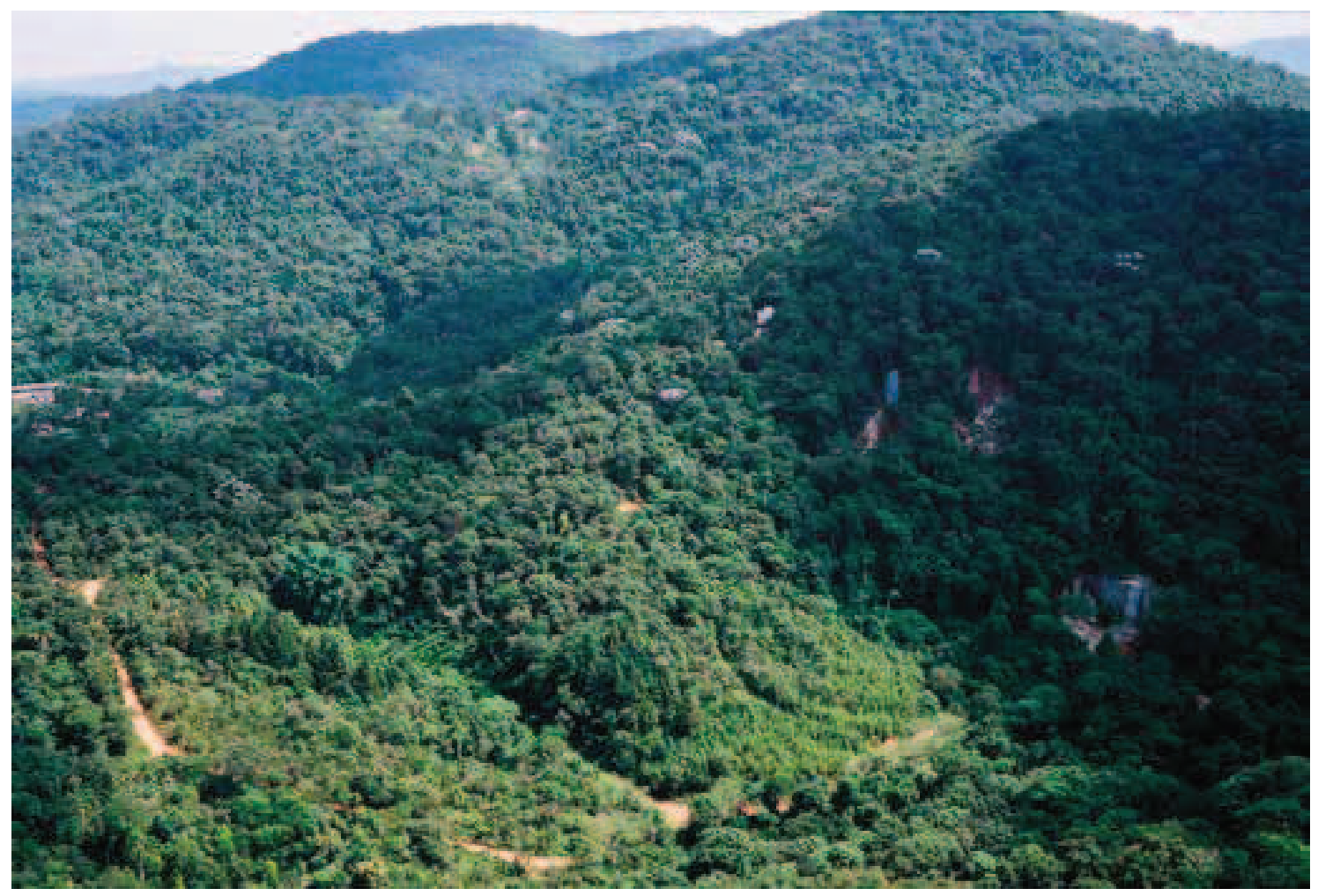

Figura 5 Distrito de Palmeiras - Matas Nativas. Fonte: PMS - 2008.

Observa-se que Suzano possui urbanização compacta tanto ao norte do território como ao centro, apresentando-se ao sul de forma fragmentada. Verifica-se, ainda, que 
tais ocupações também se colocam de maneira conflituosa ao sul, em função da sua forte inserção em áreas densamente ocupadas por águas e matas, que, na verdade, deveriam ser preservadas.

O município, de $206,60 \mathrm{~km}^{2}$, contava com população de 262.480 habitantes, o que resultava em densidade demográfica de 1.275,43 hab./ $/ \mathrm{km}^{2}$, sendo dividido em três distritos distintos: Boa Vista e Central - onde se concentram as maiores densidades populacionais da região - e Palmeiras, que se caracteriza por ocupações mais esparsas e encravadas na vegetação'.

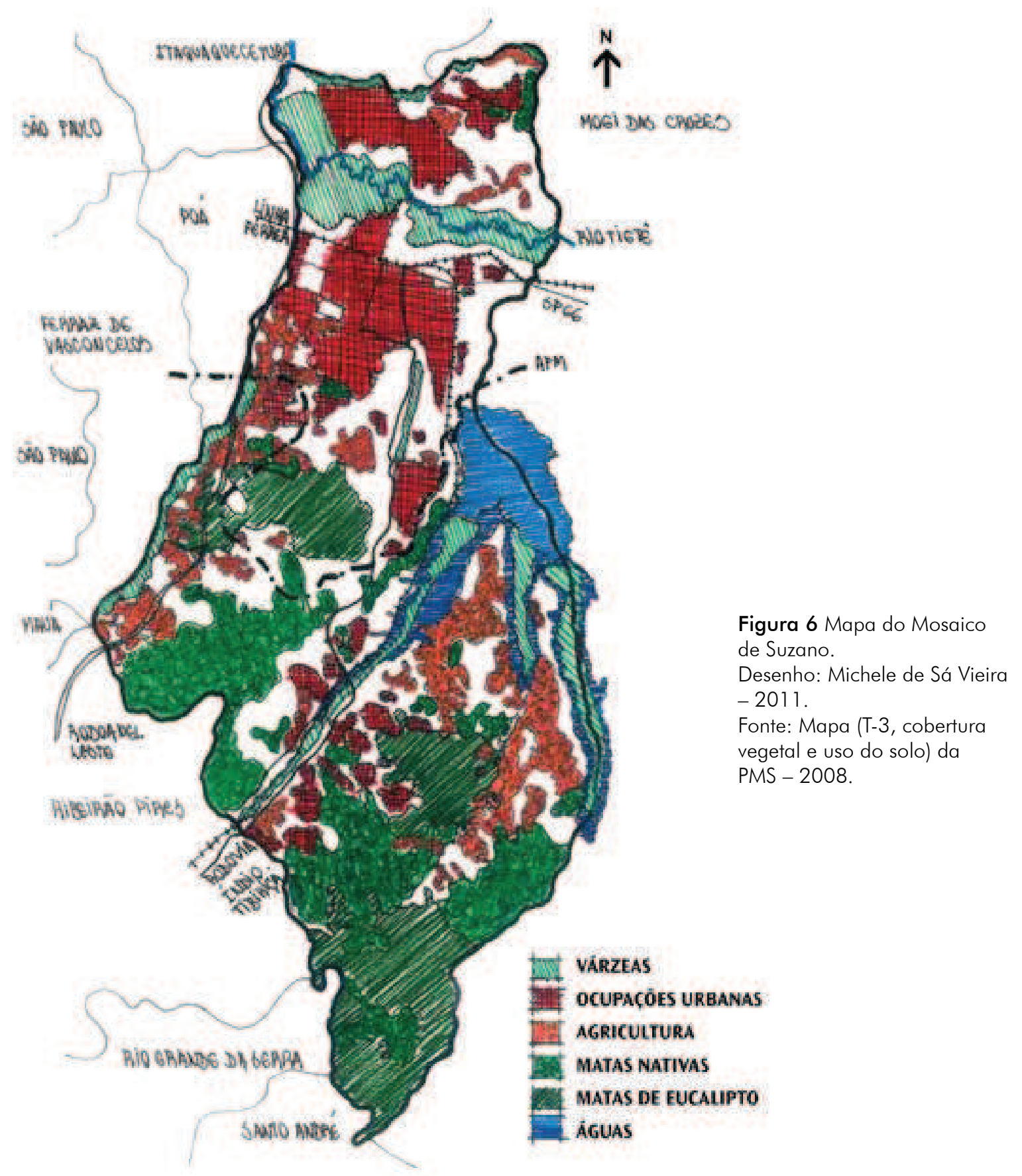

Segundo o censo do Instituto Brasileiro de Geografia e Estatística (IBGE) em 2010. Disponível em: $<$ http://www.ibge.gov.br/cidadesat/painel/painel.php?codmun=355250>. Acesso em: 6 jun. 2011. 


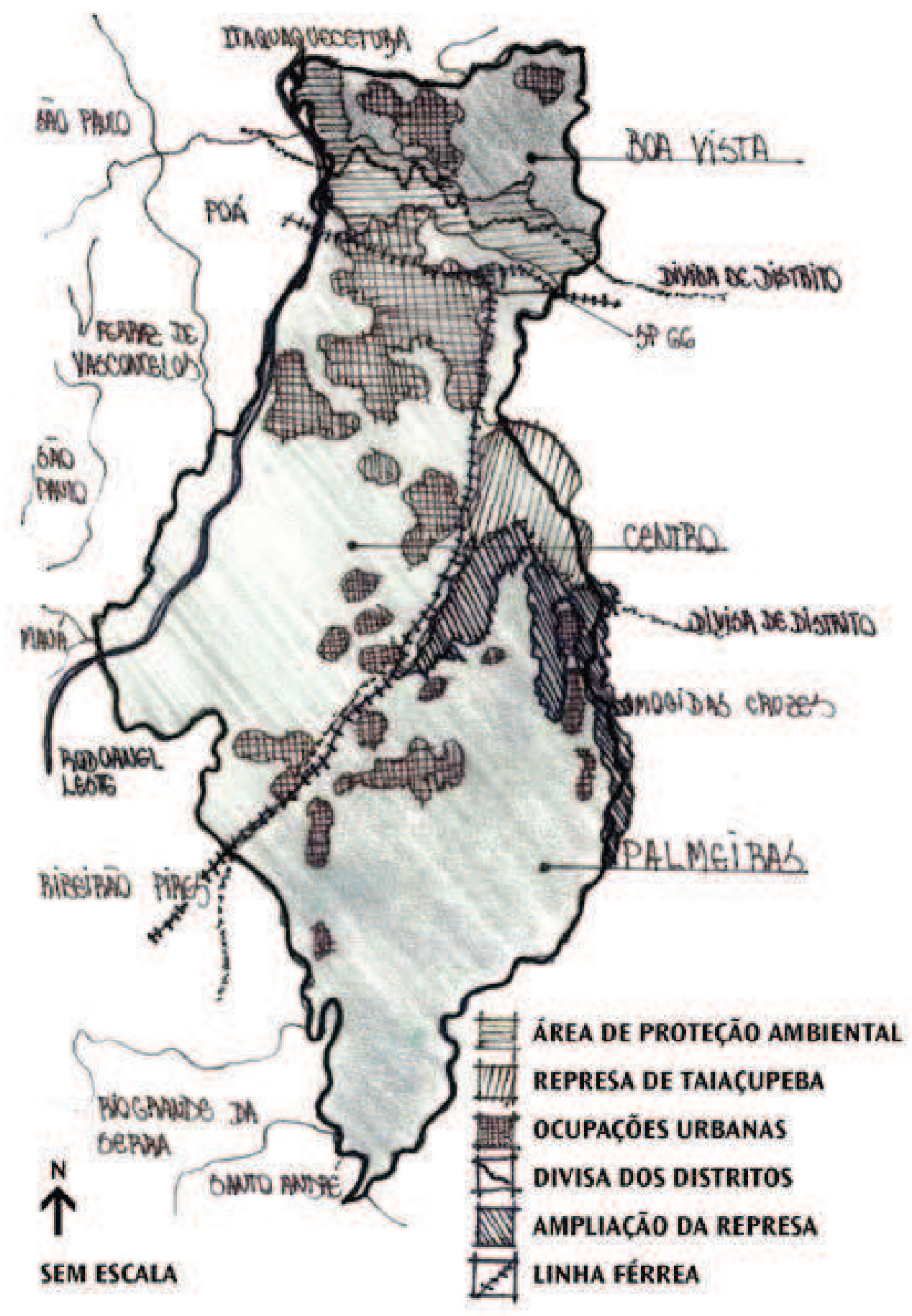

Figura 7 Mapa com a divisão dos distritos de Suzano.

Desenho: Michele de Sá Vieira - 2011.

Fonte: Mapa (T-1, áreas verdes, distritos e recursos hídricos) da PMS - 2008.

No que se refere à contextualização regional, o território municipal de Suzano, situado dentro da Bacia Hidrográfica do Alto Tietê Cabeceiras, está em área de domínio de mata atlântica, contendo uma porção de várzea do rio Tietê bastante intacta no lado norte e possuindo 73\% de seu espaço inserido em Área de Proteção dos Mananciais (APM) da metrópole paulistana. 


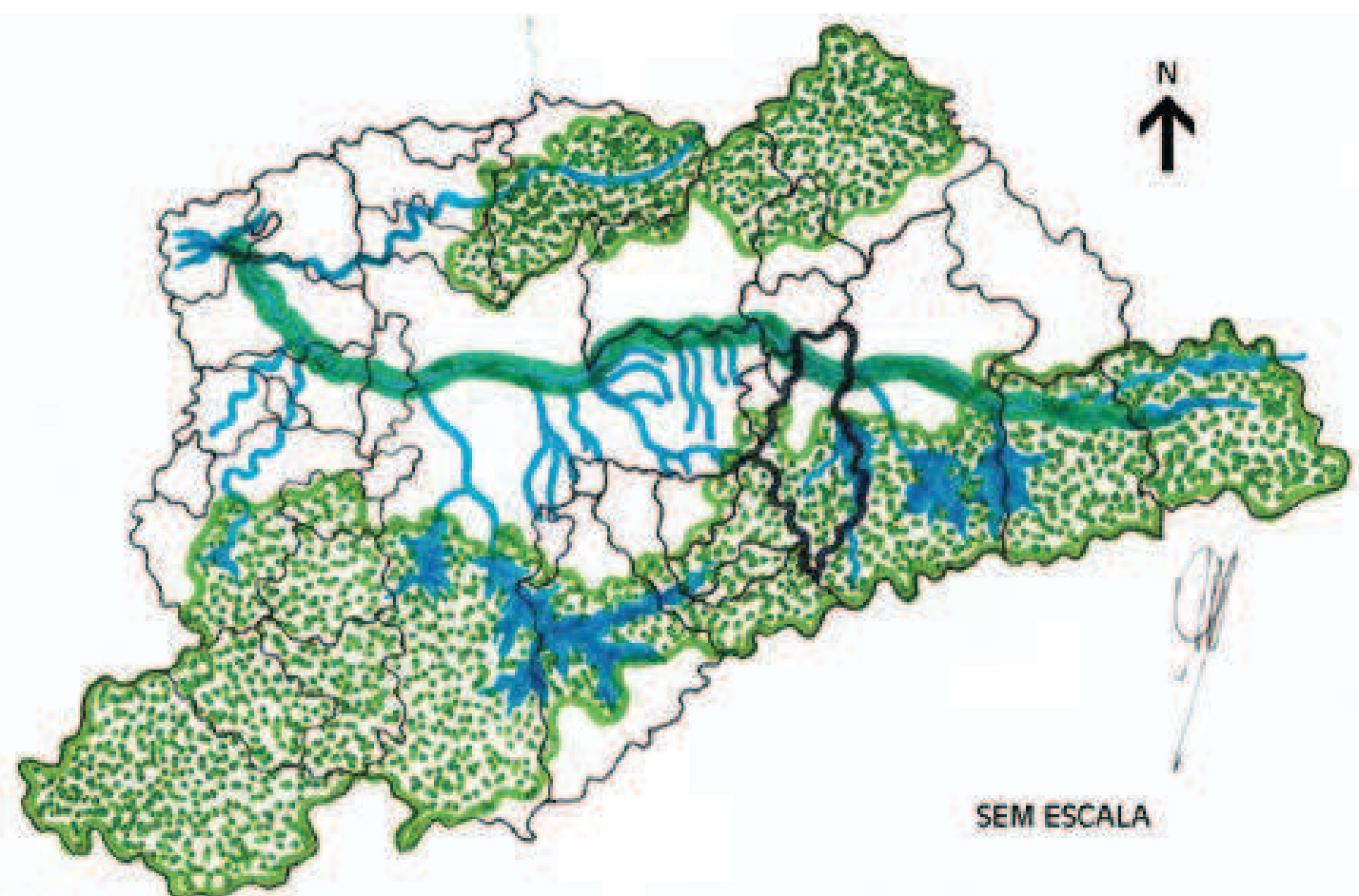

\section{Fü MUNICIPIOS QUE COMPÕEM A METRÓPOLE PAULISTANA

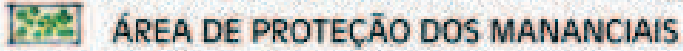 \\ D. VÁRZEA DO RIO TIETÉ \\ DUZANO}

Figura 8 Mapa com a delimitação da APM e a localização da várzea do rio Tietê.

Desenho: Michele de Sá Vieira - 2012.

Fonte: Mapas do Plano de Bacia do Alto Tietê e Empresa Paulista de Planejamento Metropolitano SA (EMPLASA) 2002.

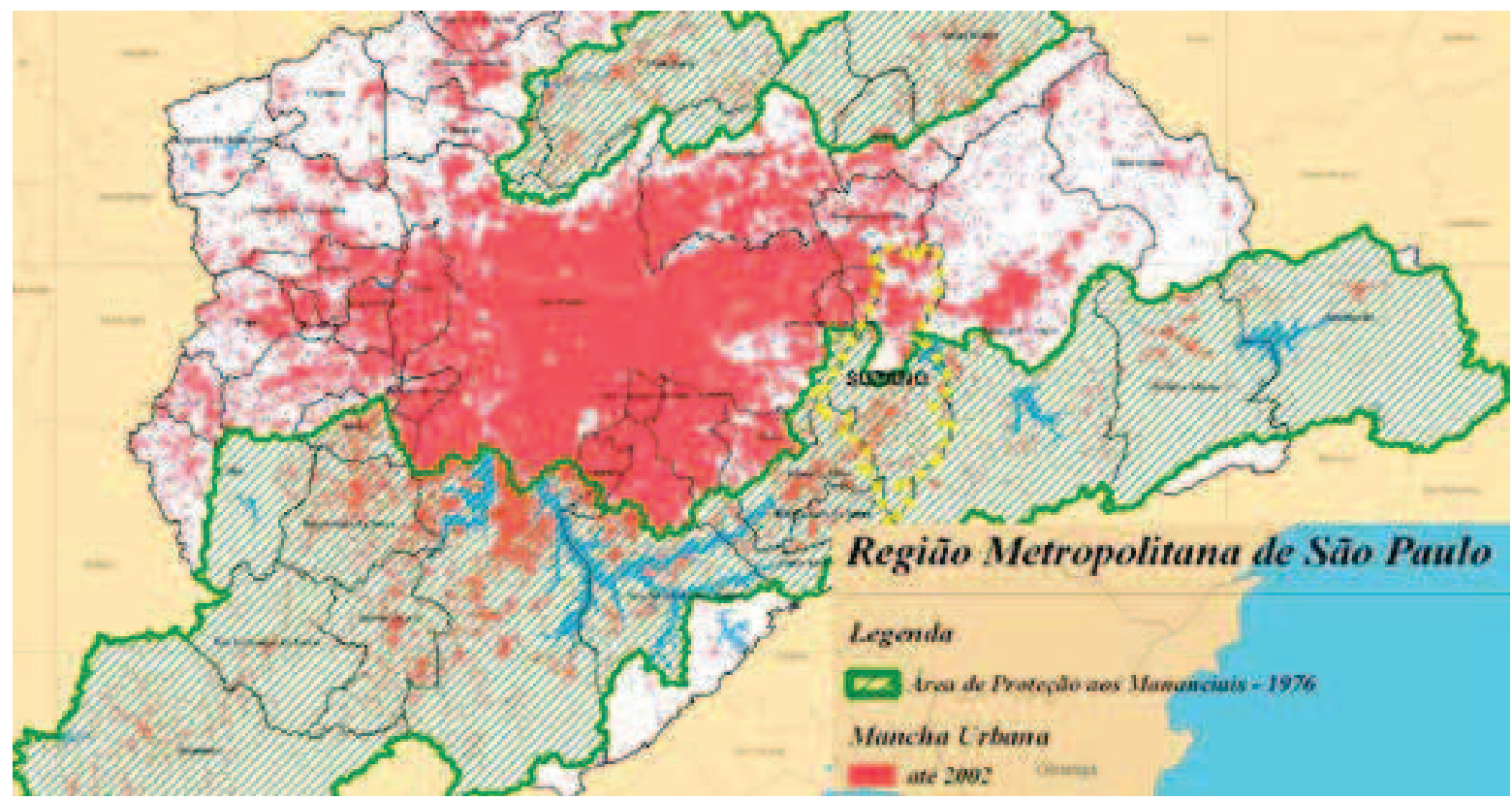

Figura 9 RMSP - Setor Leste: APM e mancha urbana até 2002. Em Suzano, as ocupações que se deram nesta área, protegida por legislação estadual, causaram a destruição de diversos sistemas hídricos e fragmentos florestais.

Fonte: EMPLASA - 2002. Sem escala. 




Figura 10 RMSP - Setor Leste. Observa-se que as ocupações urbanas na RMSP estão concentradas ao norte. No entanto, apesar de protegida por lei, a APM localizada ao sul encontra-se bastante ocupada, processada e remodelada pela população.

Fonte: EMPLASA - 2002. Sem escala.

Paisagisticamente, caracteriza-se por possuir intensa vegetação natural por todo o território, com grandes fragmentos florestais naturais ainda bem conservados, meandros e vegetação preservados - especificamente ao longo da várzea do Tietê -, muitas áreas de agricultura, além da represa de Taiaçupeba, responsável pelo abastecimento de água do município.

O território se insere na Bacia do Alto Tietê e está subdividido em cinco sub-bacias. As Bacias Tietê Cabeceiras, Billings-Tamanduateí, Juqueri-Cantareira, Cotia-Guarapiranga e Pinheiros-Pirapora o compõem.

A Bacia Hidrográfica do Alto Tietê está sob a gestão do Comitê da Bacia Hidrográfica do Alto Tietê (CBH-AT), instalado em 1994, mas com funcionamento efetivo a partir de 1997. Esta unidade de gerenciamento, dos 39 territórios que compõem a RMSP2, é composta por 34 municípios da bacia.

A Sub-Bacia Hidrográfica do Alto Tietê Cabeceiras está sob a gestão do Subcomitê da Bacia Hidrográfica do Alto Tietê Cabeceiras (SCBH-ATC), "[...] um órgão colegiado, descentralizado, de caráter consultivo e deliberativo, vinculado ao Comitê da Bacia Hidrográfica do Alto Tietê (CBH-AT), criado pela Lei n 7663, de 30 de dezembro de 1991, com vistas a compatibilizar e integrar as ações em sua área de atuação, que abrange os municípios de Salesópolis, Biritiba Mirim, Mogi das Cruzes, Suzano, Poá, Ferraz de Vasconcelos, Itaquaquecetuba, Arujá, Guarulhos e São Paulo"3.

$2 \mathrm{O} \mathrm{CBH}-\mathrm{AT}$ é composto de plenário, diretoria com presidente, vice-presidente e secretaria-executiva, além de estruturar-se em cinco subcomitês e câmaras técnicas.

3 Subcomitê da Bacia Hidrográfica do Alto Tietê Cabeceiras (SBH - ATC). Disponível em:

<http://www.tietecabeceiras.com.br/institucional/sobre-o-sub-comite>. Acesso em: 16 de jan. 2012. 


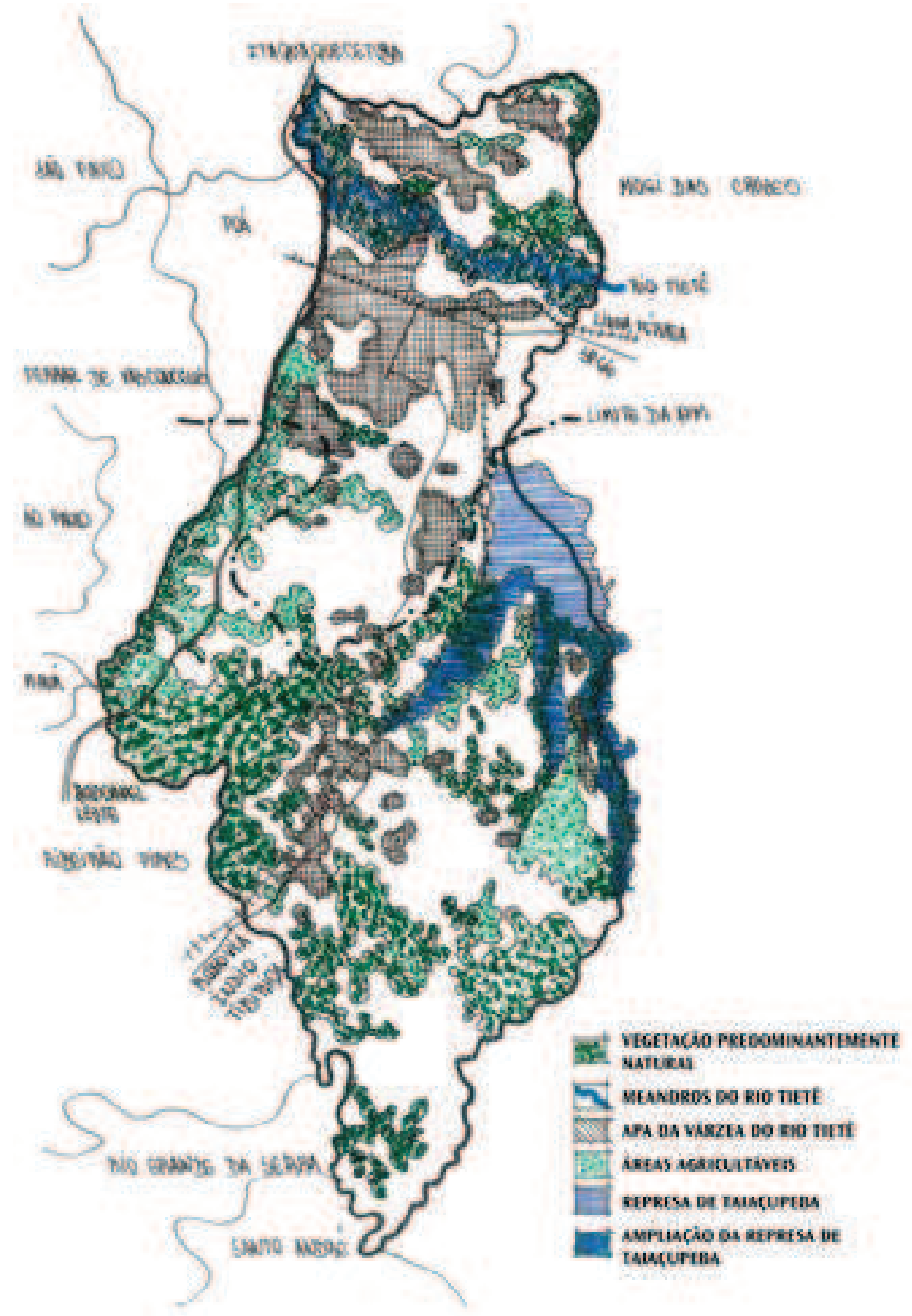

Figura 11 Mapa demonstrando as potencialidades paisagísticas do território de Suzano.

Desenho: Michele de Sá Vieira - 2012. Fonte: Mapa (T-3, cobertura vegetal e uso do solo) da PMS - 2008.

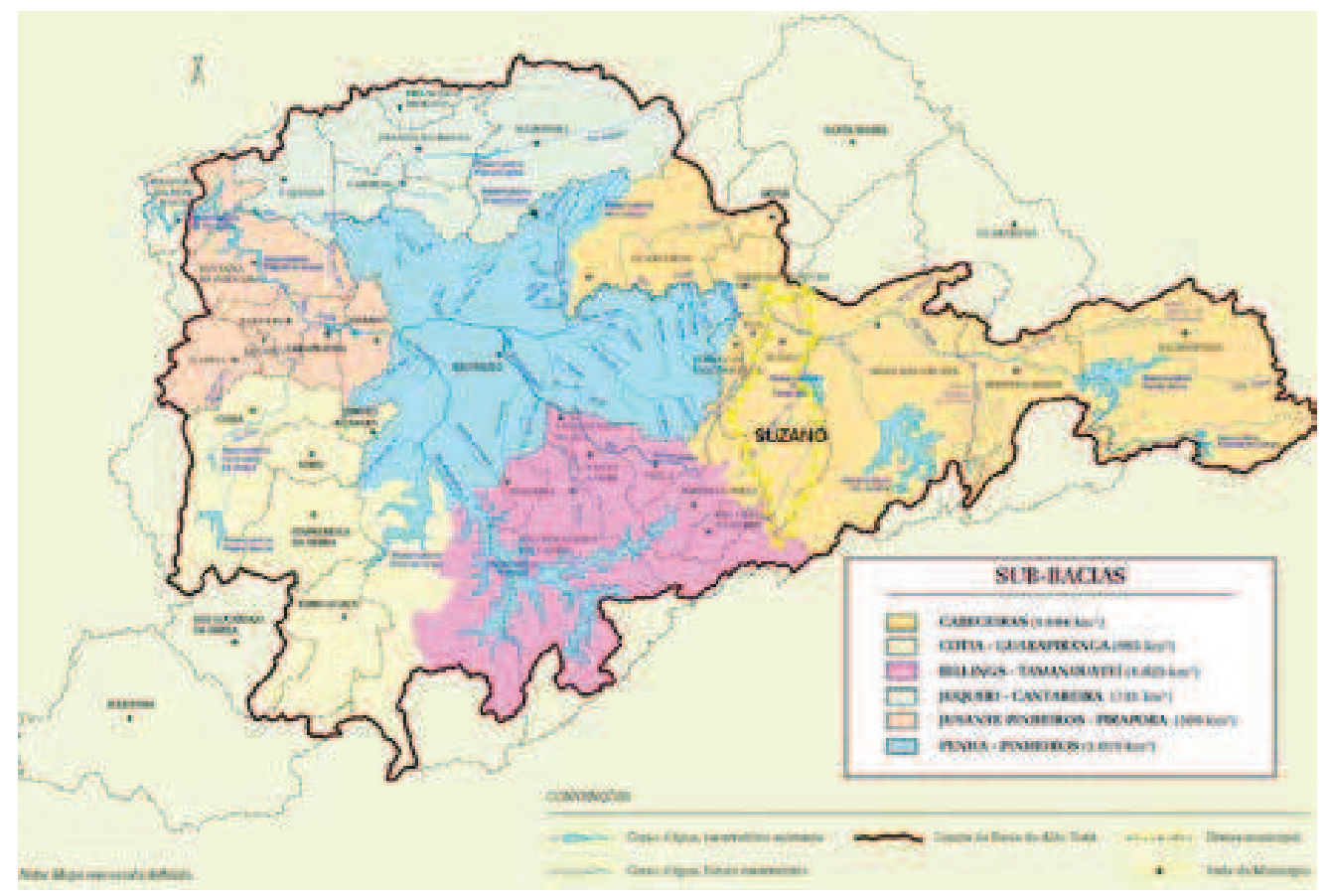

Figrua 12 Bacia do Alto Tietê, composta pela Bacia do Alto Tietê Cabeceiras, corresponde à área drenada pelo rio Tietê desde sua nascente, no município de Salesópolis, até a Barragem de Rasgão, num total de 5.985 km². Fonte: Plano de Bacia do Alto Tietê, 2002. Sem escala. 
A região do Alto Tietê Cabeceiras possui importantes reservatórios de água, colaborando com o abastecimento da RMSP em função da alta produção com relação ao recurso hídrico. O Sistema do Alto Tietê Cabeceiras (SPAT) é composto pelas represas Ponte Nova, Jundiaí, Taiaçupeba, Biritiba-Mirim e Paraitinga, localizadas próximas às cabeceiras do rio Tietê, na região dos municípios de Salesópolis, Biritiba-Mirim, Mogi das Cruzes e Suzano.

Os cinco reservatórios são interconectados por túneis, canais e sistemas de bombeamento. Na imagem abaixo, destacam-se os reservatórios de Taiaçupeba e Jundiaí, situados respectivamente em Suzano e Mogi das Cruzes.

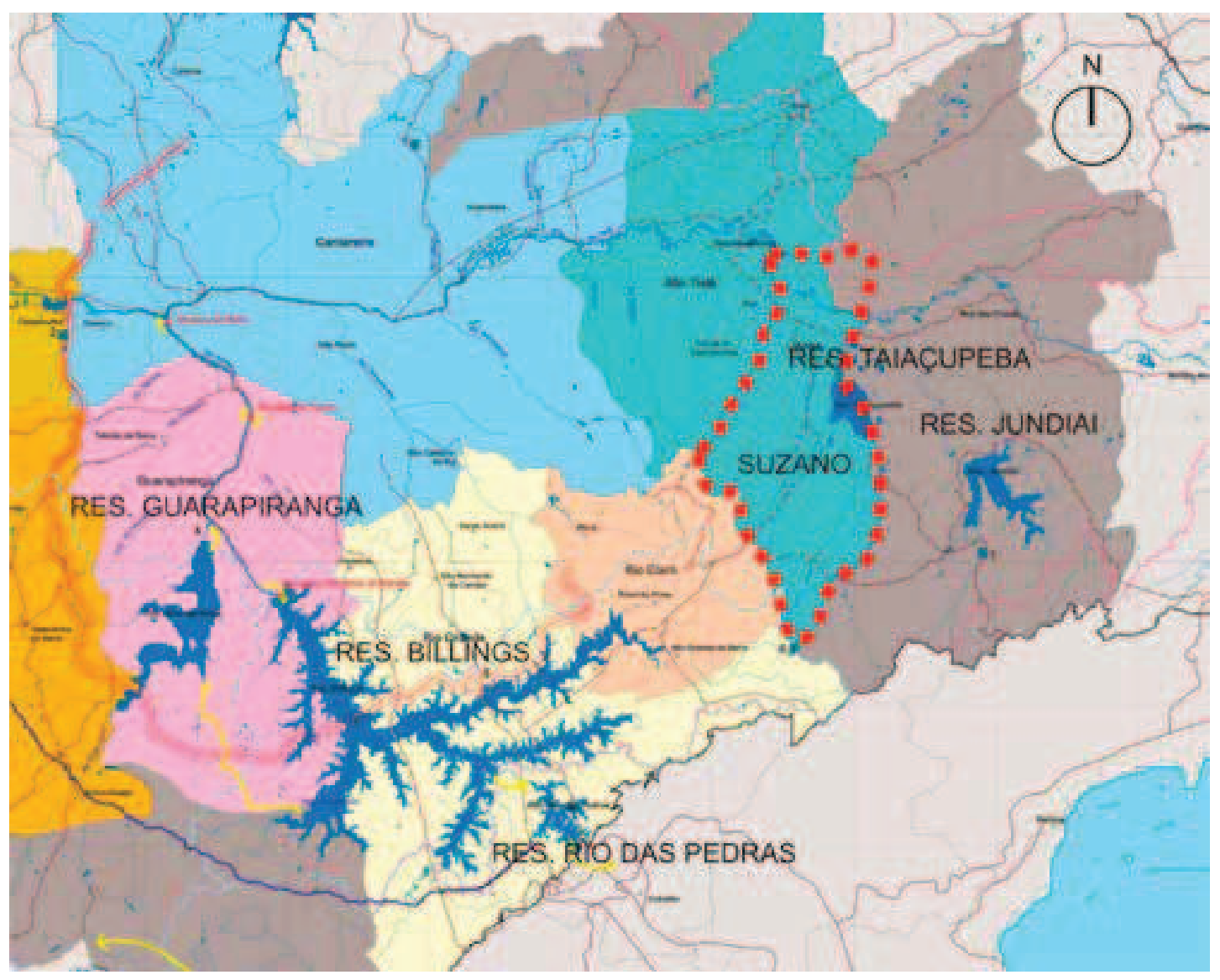

Figura 13 SPAT, ou simplesmente Sistema Alto Tietê, é um dos sistemas administrados pela Companhia de Saneamento Básico do Estado de São Paulo (Sabesp) destinado à captação, ao armazenamento e tratamento de água para a Grande São Paulo.

Fonte: Secretaria do Estado do Meio Ambiente (SMA) - 2000. Alterada pela PMS em 2008.

Outras características importantes perpassam pelo território. Além de abrigar parte do SPAT, Suzano contém parte da APA da várzea do rio Tietê, parte da várzea do rio Guaió, atividades voltadas à agricultura e à indústria, além de diversos espaços livres públicos qualificados como praças, dentre outros ${ }^{4}$.

4 Os dados referentes à indústria e à várzea do rio Guaió encontram-se desenvolvidos, respectivamente, nas unidades de paisagens 05 e 06. 


\section{APA DA VÁRZEA DO RIO TIETÊ}

Ao longo dos anos, esta área tem sofrido variadas pressões antrópicas, como o descarte de resíduos, o assoreamento do leito do rio e a especulação imobiliária. Apesar das situações adversas, a várzea do rio Tietê possui fragmentos de Mata Ciliar e planícies de alagamentos originais preservados ao longo de um percurso com 13.500 m de extensão, com zonas de vida silvestre e meandros intactos, diferentemente de muitos municípios que compõem a várzea do Tietê.
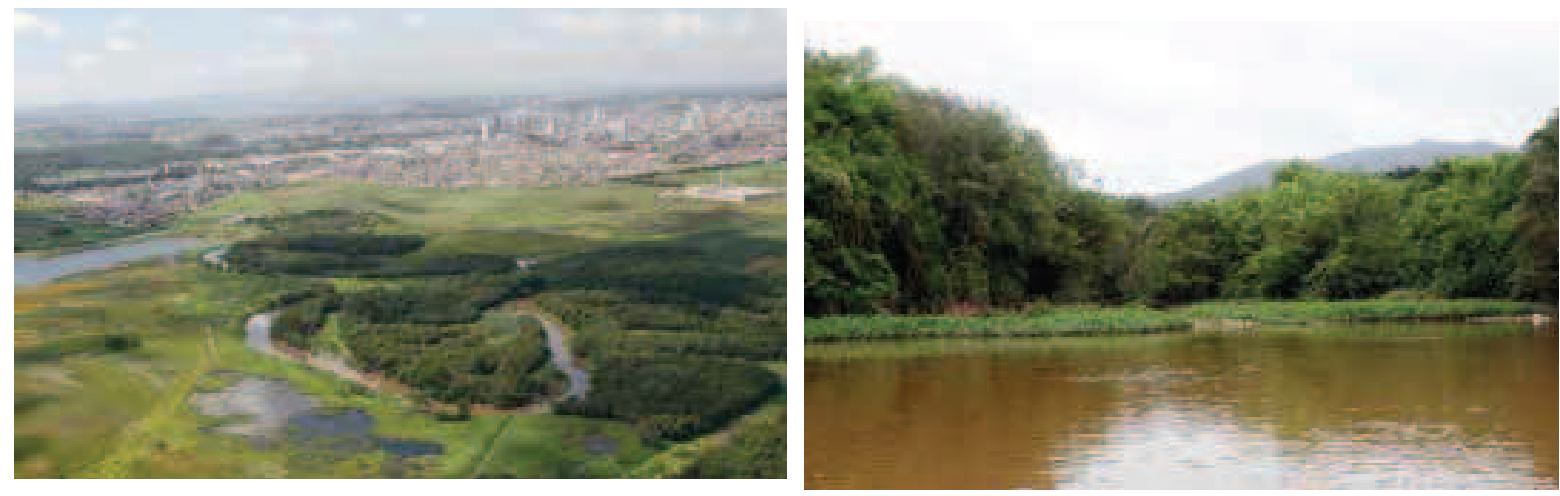

Figuras 14 e 15 Suzano: Distrito de Boa Vista. Várzea do Tietê com fragmentos e meandros bastante preservados. Fonte: Wanderley Costa. PMS - 2009.

No território de Suzano, a APA encontra-se localizada em dois distritos: Boa Vista e Central.

Ao norte, dentro do distrito de Boa Vista, a APA:

- é limitada pelo loteamento do Serviço Social do Comércio (SESC), onde se encontra o parque Mirante do Tietê;

- contém parte das Glebas 4, 5 e 7, que compõem o loteamento Cidade Miguel Badra;

- é vizinha dos loteamentos Cidade Miguel Badra (Gleba 3), Jardim Revista, Jardim Alterópolis, Jardim Gardênia Azul, Jardim Margareth, Jardim Carla e Meu Sossego.

Já ao sul, dentro do distrito Central, a APA:

- encontra-se limitada pelo loteamento Vila Maria de Maggi;

- contém parte dos loteamentos Parque Maria Helena e Vila Maluf;

- está lindeira aos loteamentos Vila Amorim, Jardim Belém, Jardim Miriam, Jardim Bela Vista e Jardim Leymar.

Por reconhecer a potencialidade vinculada à várzea do Tietê, a principal ação pública de caráter nitidamente metropolitano, prevista para os próximos anos, trata da 
implantação do projeto Parque Várzeas do Tietê - para que este espaço se volte para a população, passando a fazer parte do seu cotidiano no que se refere às atividades vinculadas à educação ambiental, ao esporte e ao lazer.

Como o projeto do Parque Ecológico do Tietê foi feito em 1976, com implantação parcial datada de 1980, o que se verifica é que esta ação pública estadual, que inicialmente transformou a várzea em APA no ano de 2010, a transforma em Parque Várzeas do Tietê5.

A retomada do projeto pelo Governo do Estado de São Paulo, através do Departamento de Águas e Energia Elétrica (DAEE), apresentou-se, em 2009, como uma oportuna medida no que se refere ao resgate ambiental deste espaço, podendo ser entendida claramente como uma iniciativa interligada às eleições presidenciais de 2010, uma vez que o ex-governador do Estado foi candidato à Presidência da República.

De qualquer forma, a proposta é uma oportunidade de garantir a preservação de amplas porções da várzea do Tietê como atenuante às enchentes que periodicamente castigam a metrópole, causando perdas de toda ordem.
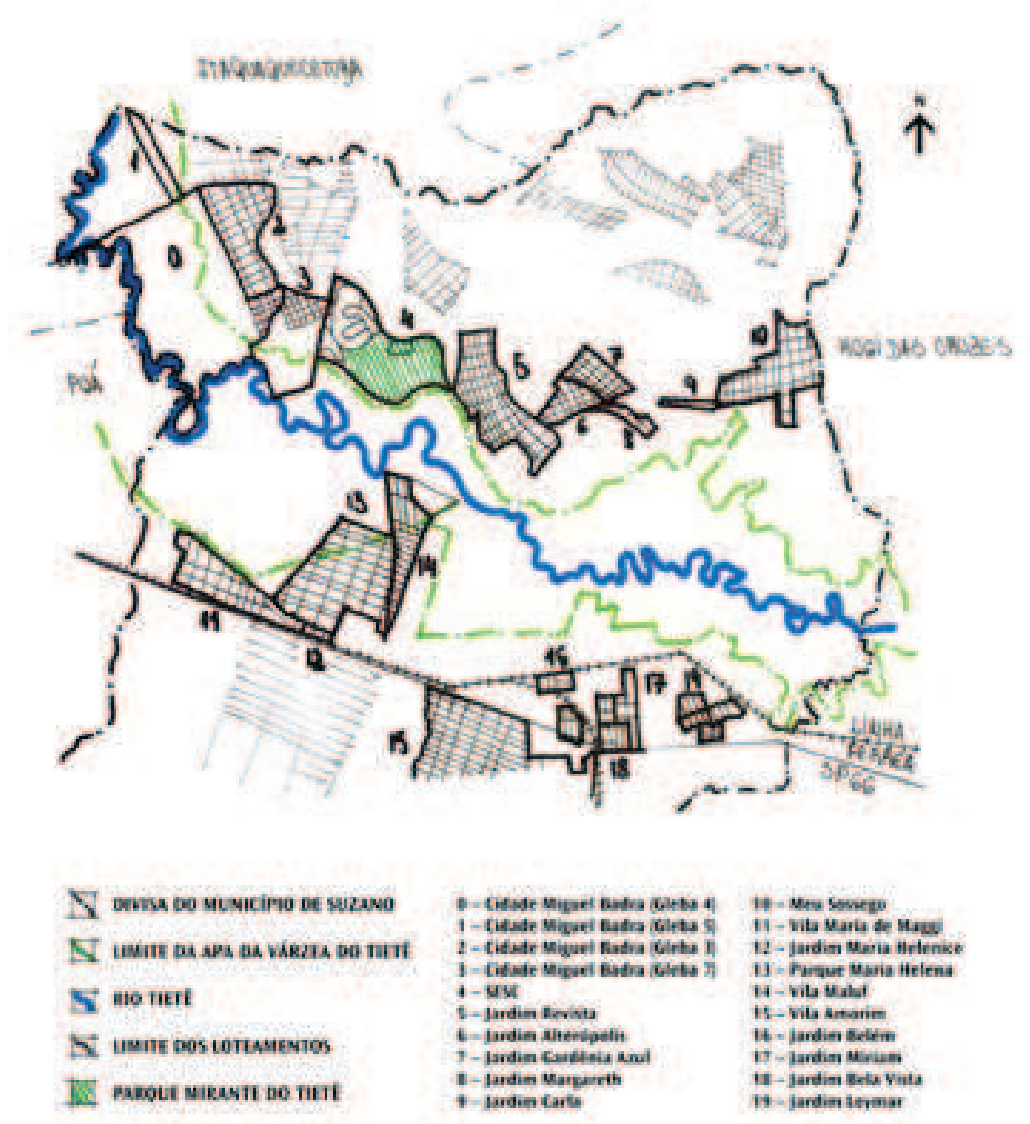

Figura 16 Mapa demonstrando a localização da APA da várzea do rio Tietê, bem como dos loteamentos próximos aos seus limites.

Desenho: Michele de Sá Vieira - 2012.

Fonte: Mapa T-5 do plano diretor de macrodrenagem da PMS - 2008.

Em 1982 foi inaugurado, pelo Governo do Estado de São Paulo, o Parque Ecológico do Tietê, mas não implantado em sua totalidade. Somente dois trechos foram implantados: o de São Paulo (Barragem da Penha) até o município de Guarulhos e de Tamboré em Barueri. 


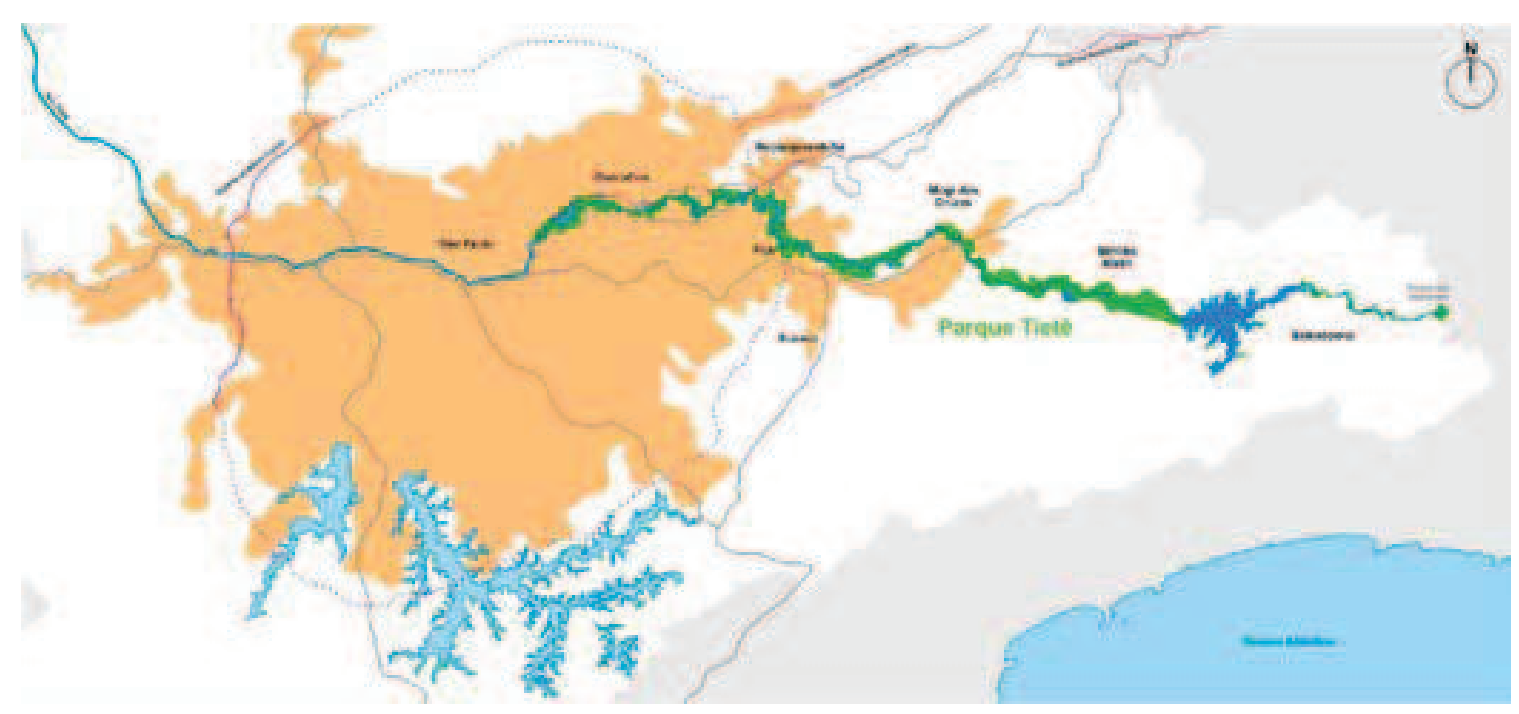

Figura 17 Proposta de localização para o futuro parque Várzeas do Tietê - Trecho Salesópolis a São Paulo. O Parque Várzeas do Tietê, idealizado pelo arquiteto Ruy Ohtake em 1976, contempla todo o Alto Tietê Cabeceiras. Trata-se de equipamento de porte regional, envolvendo 10 municípios, com o objetivo de preservar as várzeas do rio Tietê.

Fonte: Escritório Ruy Ohtake - 2008.

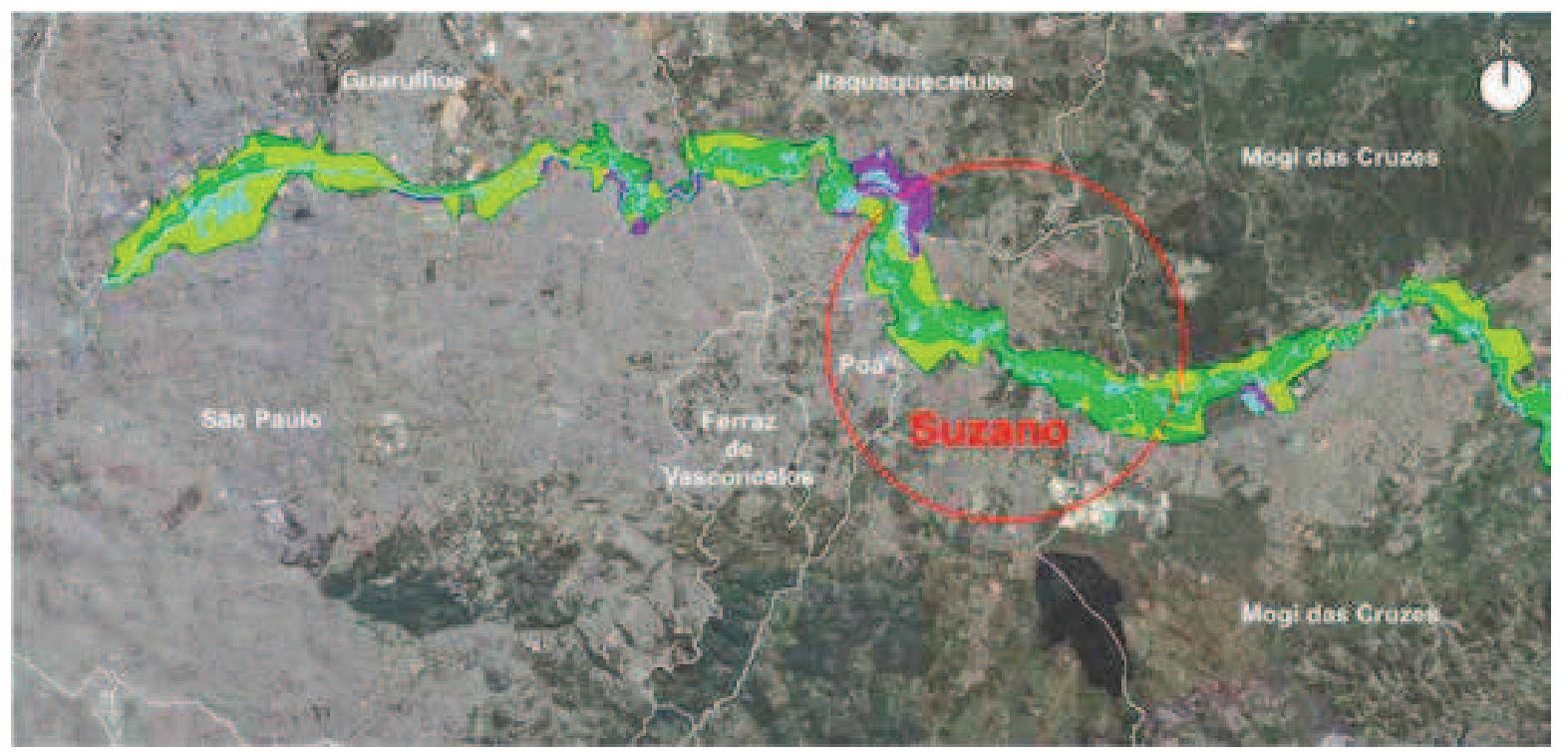

Figura 18 Proposta para o Parque Várzeas do Tietê - Trecho Suzano. Propõe uma intervenção urbano-ambiental que contempla desde o município de Salesópolis até a Barragem da Penha, com extensão de 50 km e condições para abranger mais de 1.500 hectares de área pública, surgindo como elemento organizador da paisagem e do crescimento urbano.

Fonte: Escritório Ruy Ohtake - 2008. 


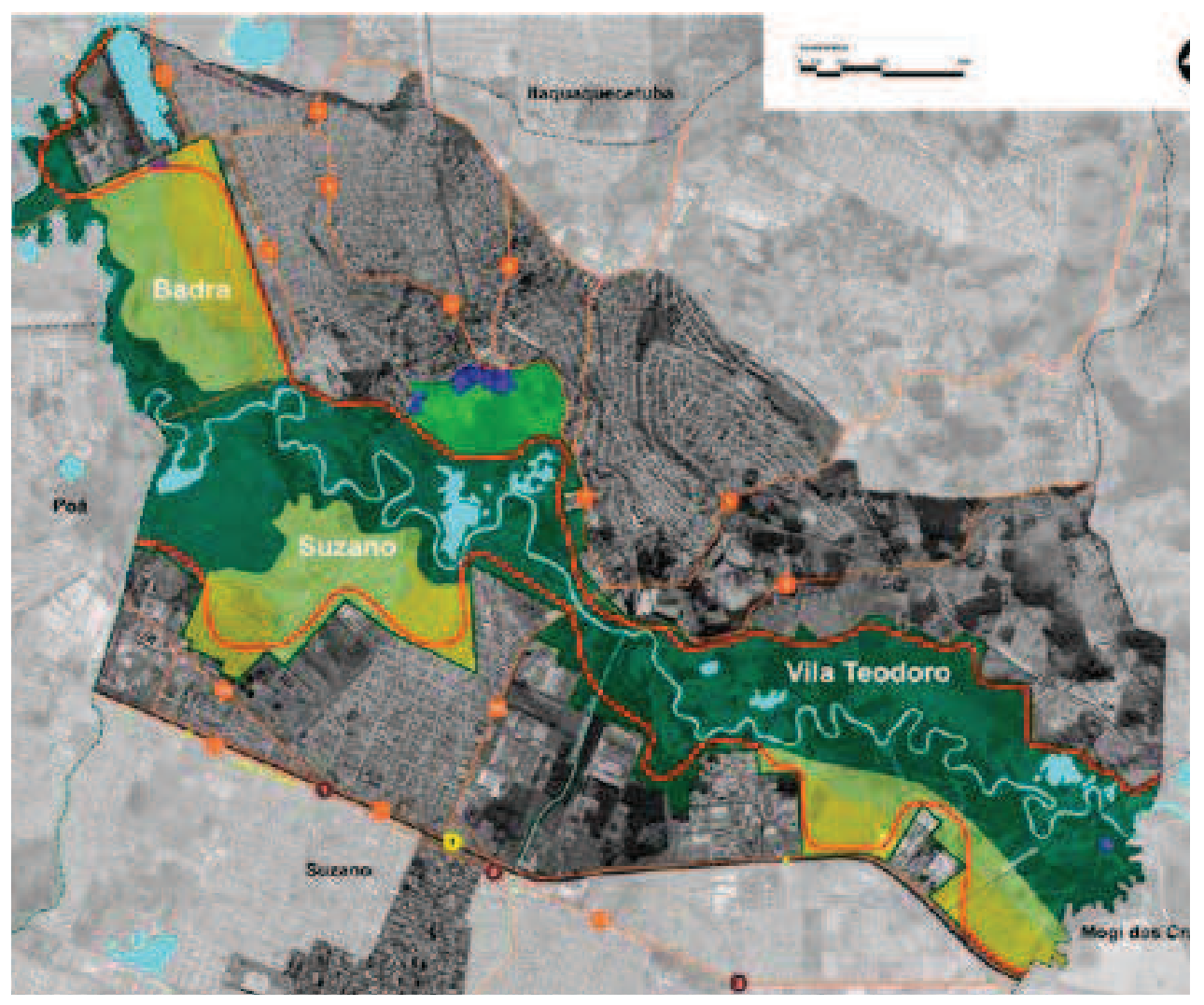

Figura 19 Para Suzano está prevista a construção de três núcleos de lazer, com programas específicos, localizados junto aos loteamentos Miguel Badra, Parque Maria Helena e outro local a ser definido. Fonte: Escritório Ruy Ohtake - 2008.

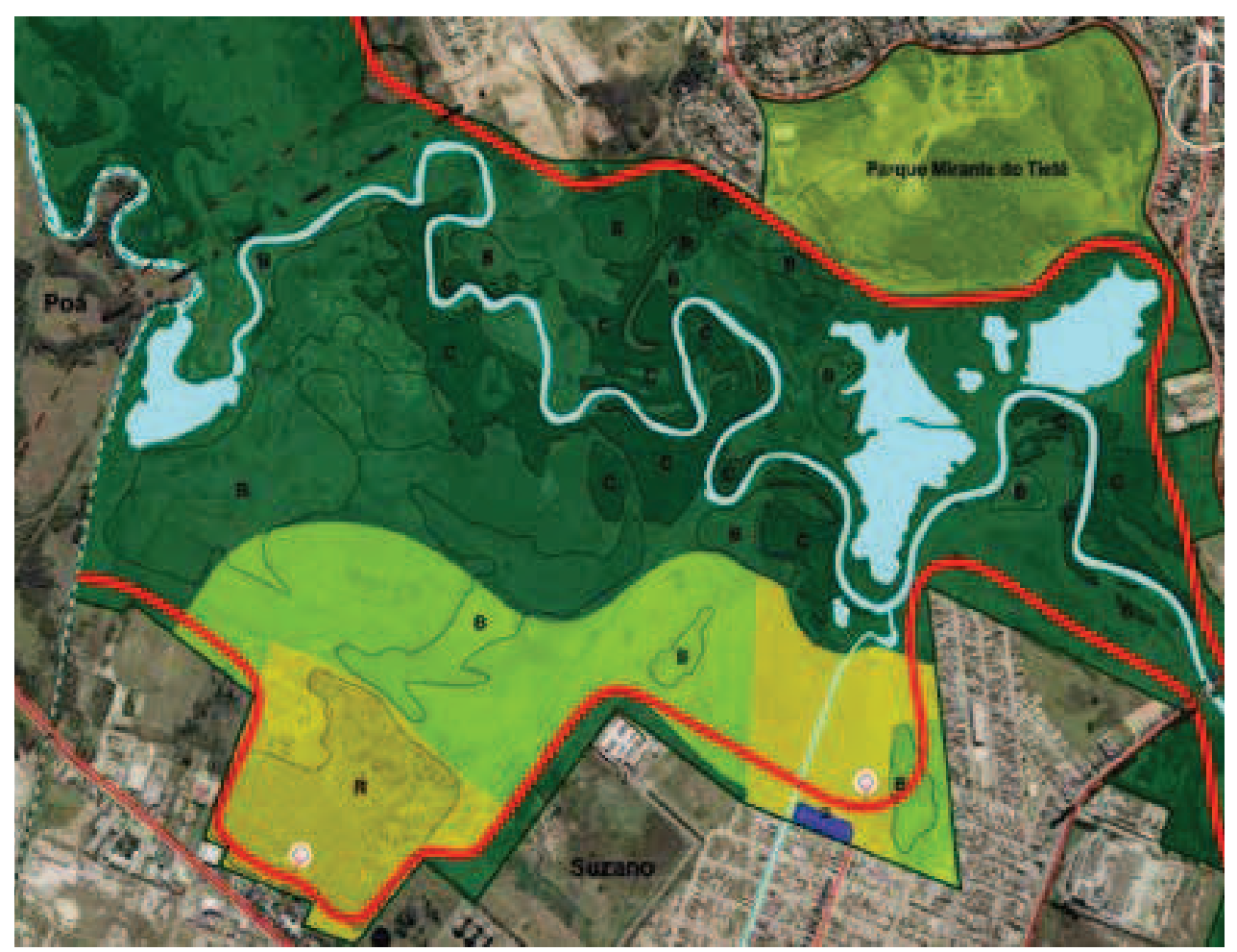

Figura 20 Proposta para o Parque Várzeas do Tietê em Suzano.

O espaço, após a implantação do projeto, terá características de um parque urbano onde a população poderá usufruir da faixa aberta que integra os equipamentos de uso social com a vegetação e a água. O parque será contemplado não somente com equipamentos de lazer, mas também com projetos de revegetação arbórea, capazes de restabelecer o ecossistema, hoje parcialmente degradado por ações antrópicas. Fonte: Escritório Ruy Ohtake - 2008. Sem escala. 
Entende-se que, em função de o município apresentar carências no que se refere às áreas de esporte, lazer e recreação, a várzea poderá ser incorporada ao sistema de espaços livres públicos do território, propiciando nova configuração para a paisagem no que se refere às atividades sociais, através da implementação de equipamentos de lazer, cultura, recreação e contemplação, mas também em função de esta ação ter a capacidade de possibilitar futuras conexões ecológicas e ambientais com outros elementos do município, como o parque Mirante do Tietê, que está ao seu lado.

No entanto, apesar de apresentar todo este potencial metropolitano, é importante analisar que o projeto, por ser de alçada estadual, vai depender de políticas futuras, (2012 em diante) a serem trabalhadas de forma compartilhada entre o governo municipal e o estadual no que se refere à sua implementação e manutenção.

\section{AGRICULTURA}

Atividade que ocupa extensos territórios do município, dado ao fato de existirem condições ideais para o seu desenvolvimento, como a alta disponibilidade de água, necessária ao cultivo das hortaliças, bem como solo fértil.

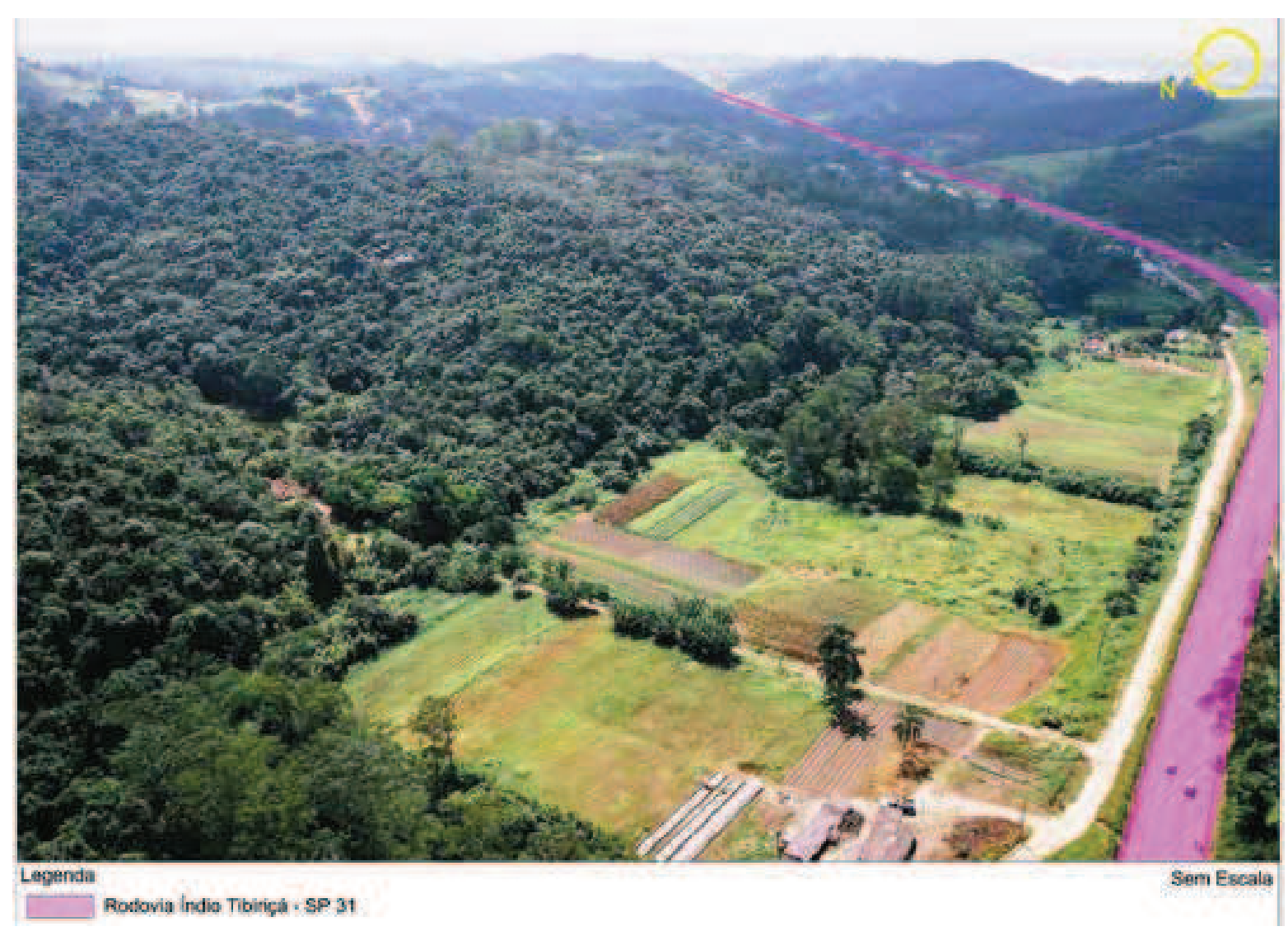

Figura 21 Suzano: Distrito de Palmeiras. Presença da vegetação nativa junto à agricultura nas margens da rodovia Índio Tibiriçá. Percebe-se que nesta região do território parte da vegetação nativa foi suprimida para que se pudesse implementar a agricultura.

Imagem elaborada por Michele de Sá Vieira e Sanderlei Fernandes Vilanova - 2012.

Fonte: PMS - 2008 . 


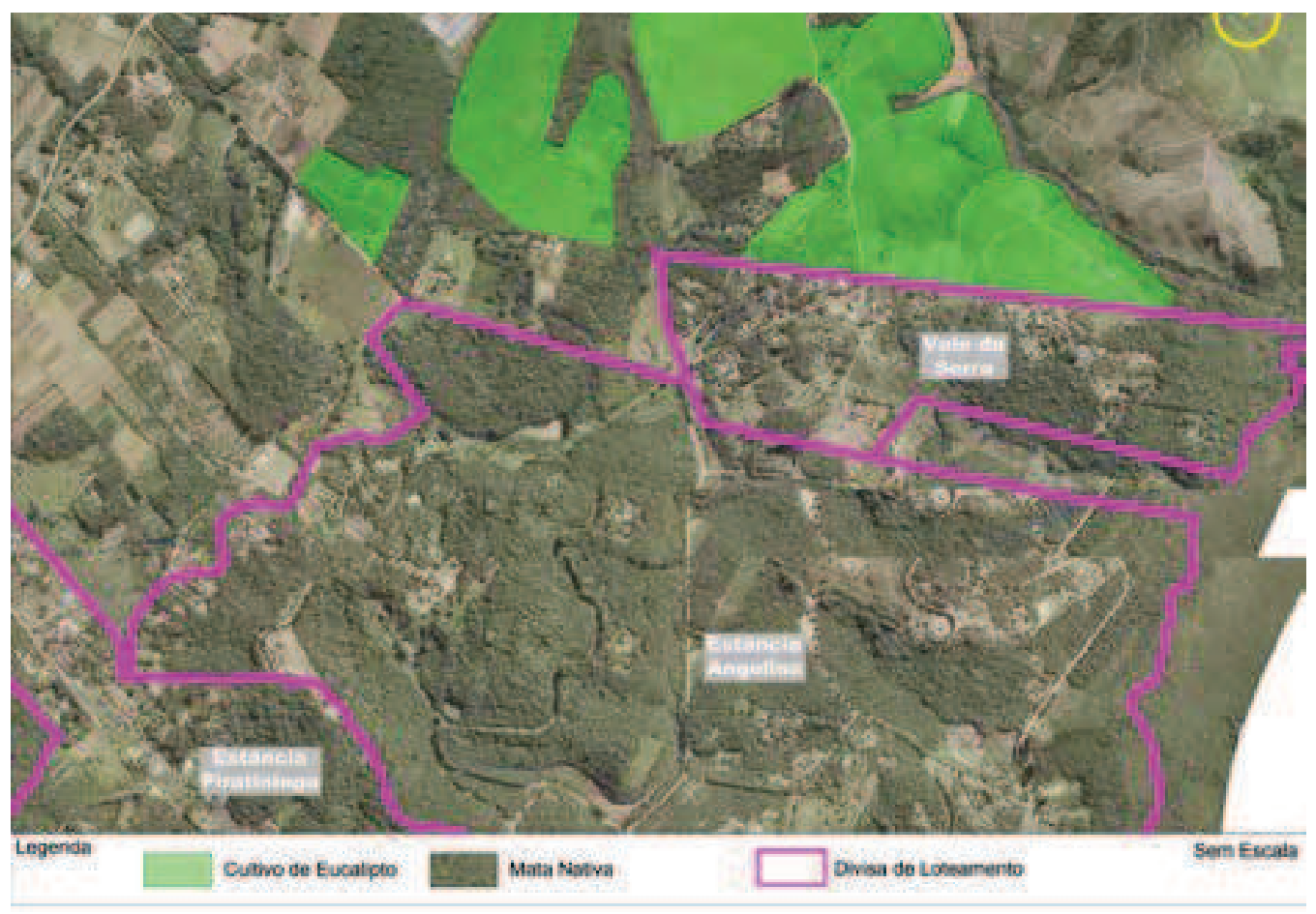

Figura 22 Loteamentos Vale da Serra, Estância Angelina e Estância Piratininga. Apresentam sistema viário sinuoso com ocupações encravadas no meio da vegetação de mata nativa. A agricultura também se faz presente no Distrito de Palmeiras, que, juntamente com os eucaliptos e as ocupações, acaba por contribuir com a diminuição dos fragmentos de mata nativa.

Imagem elaborada por Michele de Sá Vieira e Sanderlei Fernandes Vilanova - 2012.

Fonte: PMS - 2008.

\section{ESPAÇOS LIVRES PÚBLICOS}

Quanto aos espaços livres públicos urbanos, existem no território com diferentes dimensões, qualificações estéticas funcionais, localizações e características, podendo ser configurados por calçadas, vias, praças, parques.

O que se compreende é que em Suzano os espaços livres públicos:

[...] podem servir tanto para as organizações de usos e fluxos como podem ser simples ajardinamentos. Há aqueles que melhoram a condição de vida da comunidade; aqueles que mudam a maneira como os lugares são usados e percebidos; e que podem, por isso, levar a outras transformações ${ }^{6}$.

Para tanto, seguem exemplos de ações produzidas para:

a) organização de usos e fluxos e mudança da maneira como os lugares são percebidos; 


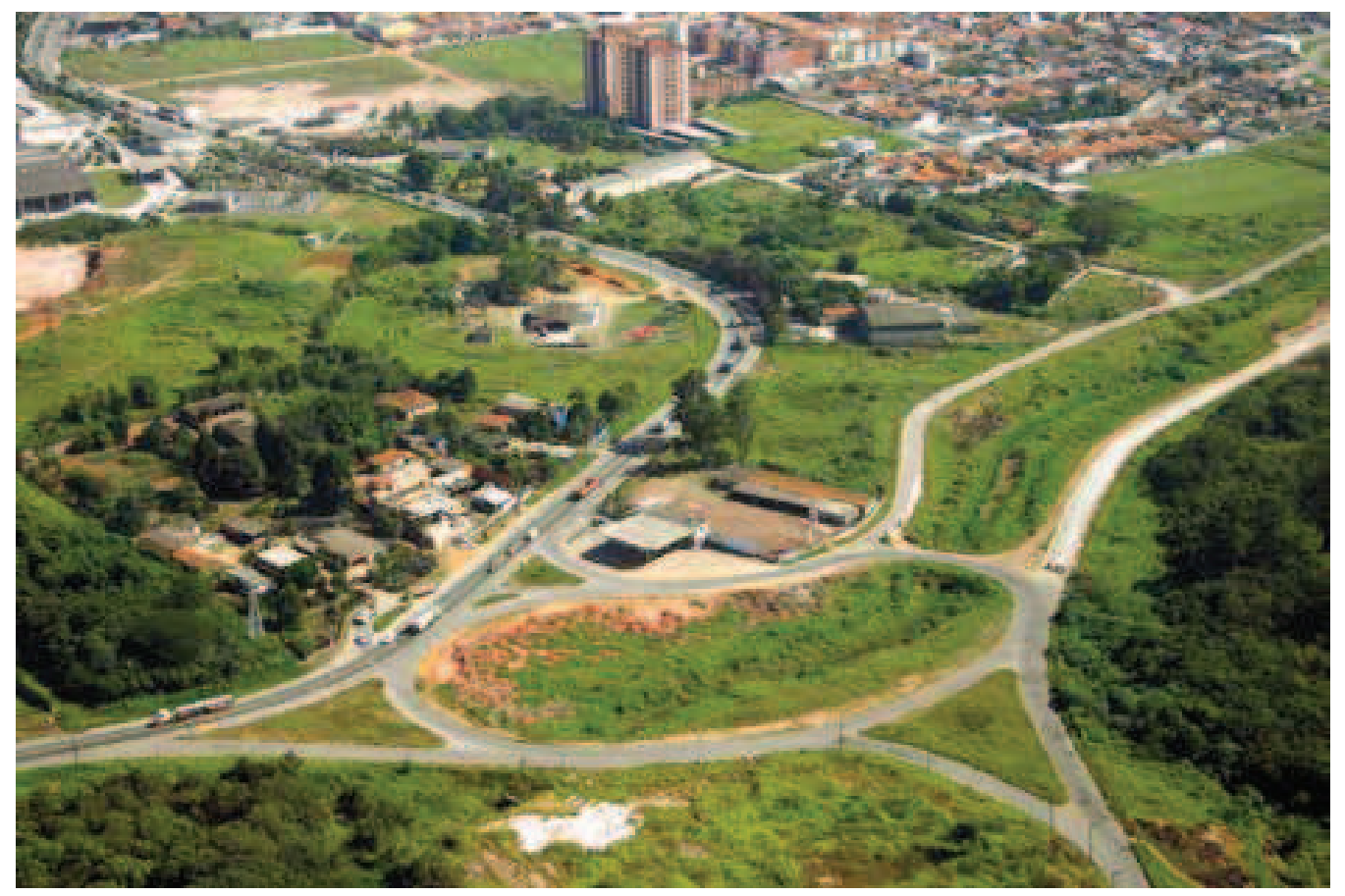

Figura 23 Suzano. Rotatória junto à avenida Governador Mário Covas Junior (Marginal do Una). Tinha como função somente organizar o trânsito.

Fonte: PMS - 2008.

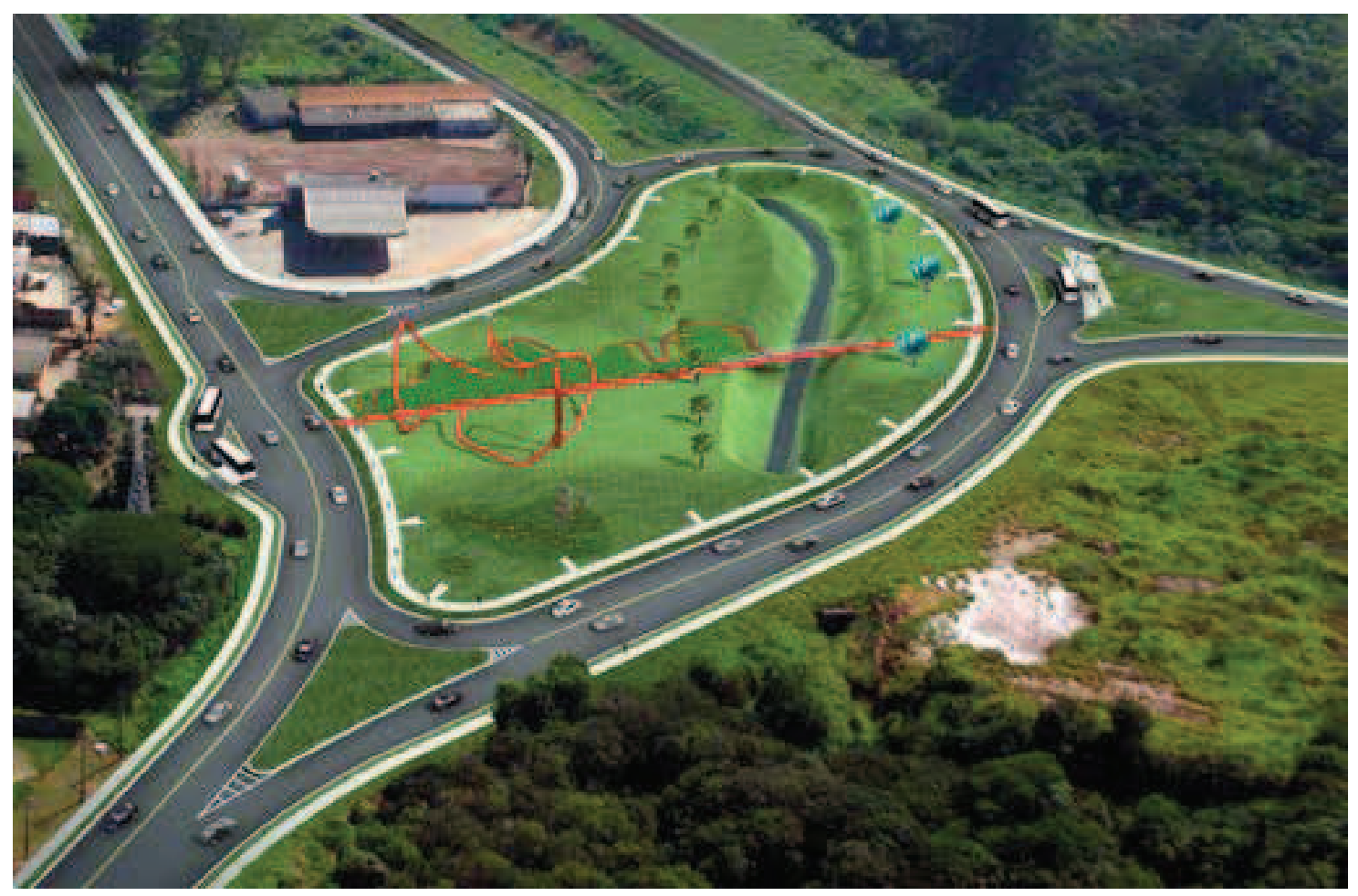

Figura 24 Suzano. Esta rotatória é um exemplo de como um espaço livre em Suzano pode mudar a maneira como um local pode ser percebido. Anteriormente, a rotatória junto à avenida Governador Mário Covas Junior (Marginal do Una) tinha como função somente organizar o trânsito. A partir de novas ações que se deram sobre ela, este espaço passou a guardar uma escultura elaborada pela artista plástica Tomie Ohtake, em comemoração ao centenário da imigração japonesa no Brasil, assumindo um novo significado urbano e transformando-se em marco referencial da cidade.

Fonte: Arquivo Meng Tsai - 2008. 
b) organizar a totalidade do espaço urbano e mudar seu uso;

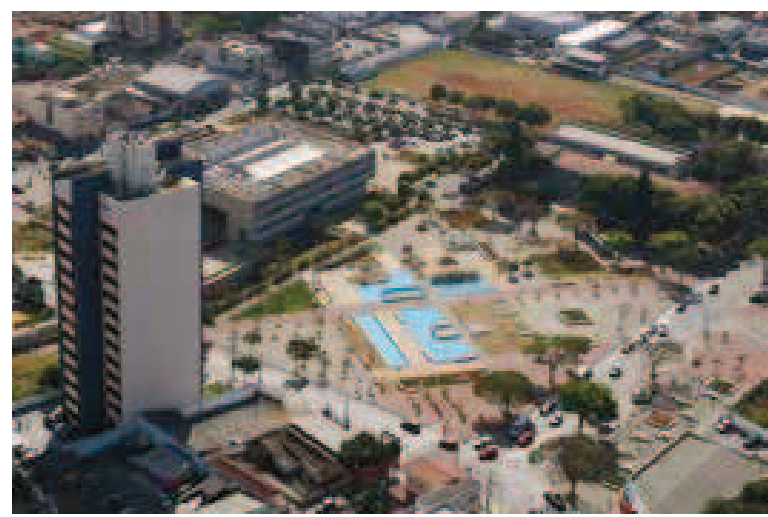

Figura $25 \mathrm{~A}$

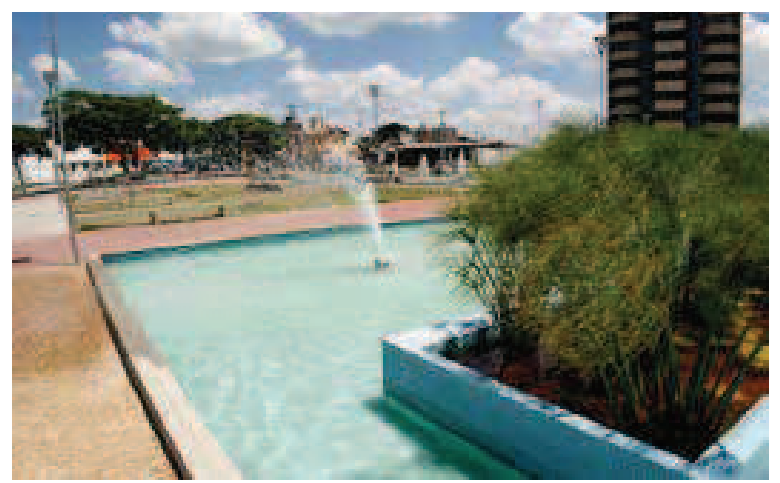

Figura $25 \mathrm{C}$

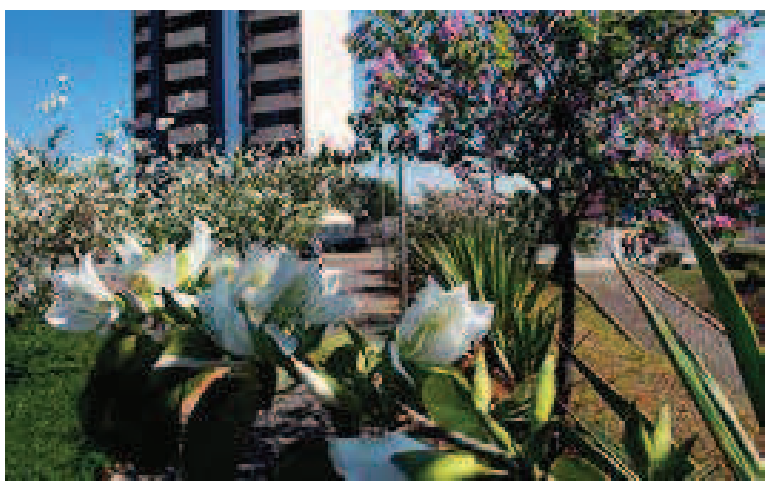

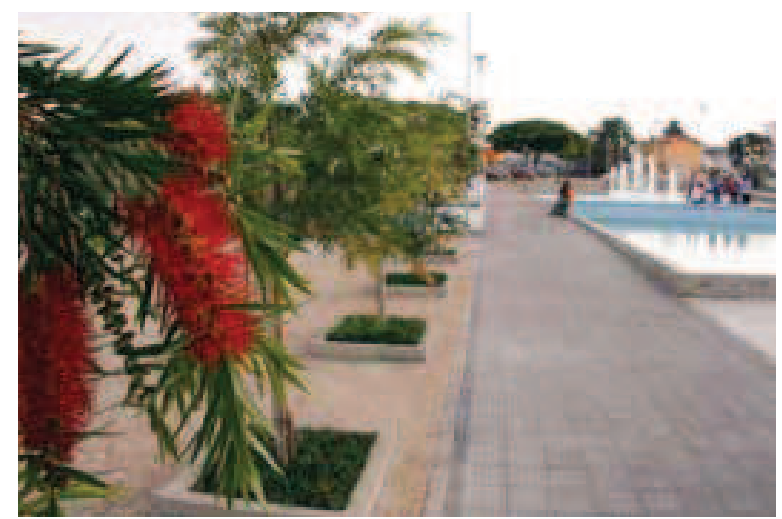

Figura 25 B

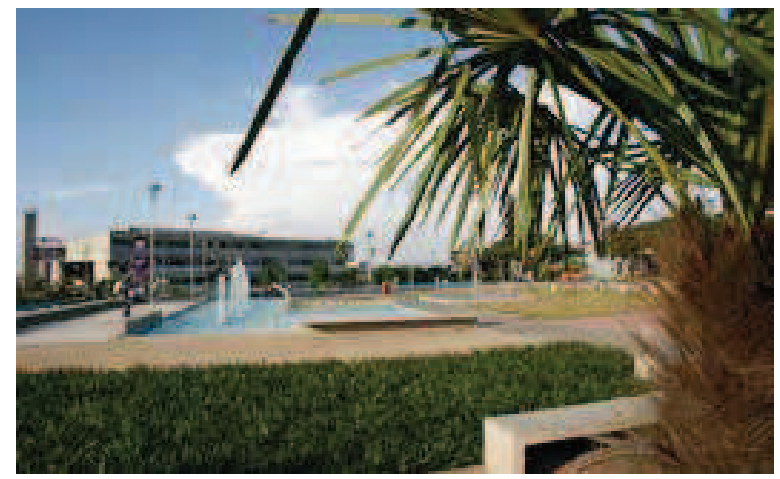

Figura 25 D

Figuras 25 A, B, C, D e E.

Suzano. Praça Cidade das Flores: exemplo de significados estruturais, considerando-se que o espaço preexistente era utilizado como estacionamento. Neste momento o local atende a atividades voltadas ao lazer e à recreação. Fonte: Wanderley Costa. PMS - 2008.

Figura $25 \mathrm{E}$

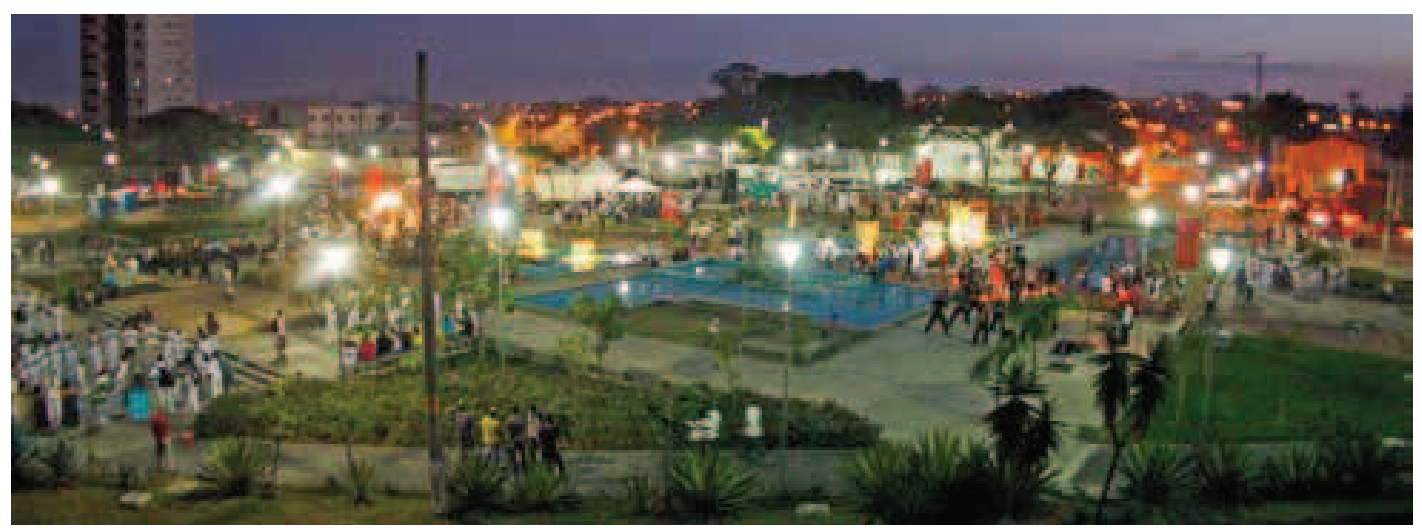

Figura 26 Suzano. A praça Cidade das Flores estimula atividades vinculadas ao convívio público e possui a capacidade de estabelecer troca de experiências, vivências, sonhos e ansiedades da sociedade, através de atividades de todos os tipos, como a "Roda de Todos os Santos". Fonte: Wanderley Costa. PMS - 2011. 


\section{A APLICAÇÃO DO MÉTODO E A GESTÃo PÚBLICA}

Por vezes, no cotidiano da administração pública municipal, atores sociais (como os chefes do executivo e legislativo, secretários, vereadores, associações de bairros, cidadãos, instituições de classes, autarquias, organizações não governamentais, dentre outros), solicitam o desenvolvimento de planos e projetos com o intuito de obter recursos para atender a determinadas solicitações.

Algumas vezes, estas visam beneficiar grande parte da população, com políticas públicas que realmente contemplam o território, trazendo qualidade de vida para os munícipes. Por outro lado, há aquelas que buscam atender interesses específicos, com fins eleitoreiros, através de políticas pontuais que privilegiam uma parcela restrita.

Dessa forma, a criação de um método de análise a partir das unidades de paisagem contribui para reflexões: parcial do território, através do estudo de cada unidade; geral, ao consideramos a síntese de todas as unidades de paisagem; comparativa, em função de similaridades e diferenças.

A partir dessa análise, é possível embasar a tomada de decisões com relação aos investimentos a serem destinados ao município pelo poder público, sob um viés ou vários, dado ao fato de o estudo apontar onde se encontram:

- os conflitos e fragilidades, a exemplo dos temas ambientais a serem resolvidos, administrados e superados;

- as potencialidades que podem ser valorizadas e ressaltadas, tais como as paisagens naturais;

- os investimentos já realizados e quais áreas e locais ainda precisam receber maiores investimentos;

- as unidades de paisagem que necessitam receber maior investimento, bem como as que foram amplamente atendidas pelo poder público;

- a quantificação das obras e áreas que tiveram os maiores investimentos, tais como transporte, educação, saúde, planejamento urbano, meio ambiente, desenvolvimento econômico;

- os dados significativos do território a serem considerados, dialogados e expostos estrategicamente junto com a sociedade, dando as informações necessárias para que possa cobrar os devidos investimentos.

Com isto, resguarda-se o controle dos cenários futuros no que se refere à solução de problemas, minimização de conflitos, ampliação e valorização de determinadas características, como as naturais, além da organização das ações das políticas que resultariam na contribuição do aumento da qualidade de vida, que se expressa através da distribuição equilibrada da renda, acesso à habitação adequada, à mobilidade, educação, cultura e conservação da natureza.

Visando conhecer Suzano, o critério de análise utilizou-se da subdivisão do município em 10 unidades de paisagens que possuem formas orgânicas, bem como tamanhos 
distintos, delimitadas em função da concentração significativa de determinadas características ao longo da extensão territorial, tais como: relevo, densidade dos loteamentos ocupados, concentração das indústrias, localização das plantações de hortigranieiros e das chácaras e também dos fragmentos de mata nativa, capoeiras, campos, eucalipto, presença de vegetação de várzea, existência da APA da várzea do rio Tietê, grandes áreas de interesse ecológico, ambiental e paisagístico, existência das ocupações urbanas com bom padrão de urbanização (ou não) - como sistema viário, iluminação, saneamento, espaços livres.

Foram utilizados: Mapa do Uso e Ocupação do Solo da Empresa Paulista de Planejamento Metropolitano SA (EMPLASA), imagem aerofotogramétrica da Prefeitura Municipal de Suzano (PMS), bem como do Google Maps, além de fotos aéreas de determinados espaços do município, que permitem ao leitor apropriar-se de locais específicos das unidades de paisagem.

Dessa forma, o artigo, que inicialmente aponta a subdivisão das unidades de paisagem nos mapas do Google Maps e uso e ocupação do solo para todo o território, em um segundo momento apresenta as 10 unidades de paisagem em escala maior, permitindo o aprofundamento em relação a características, conflitos e cenários futuros possíveis.

\section{UNIDADES DE PAISAGEM}

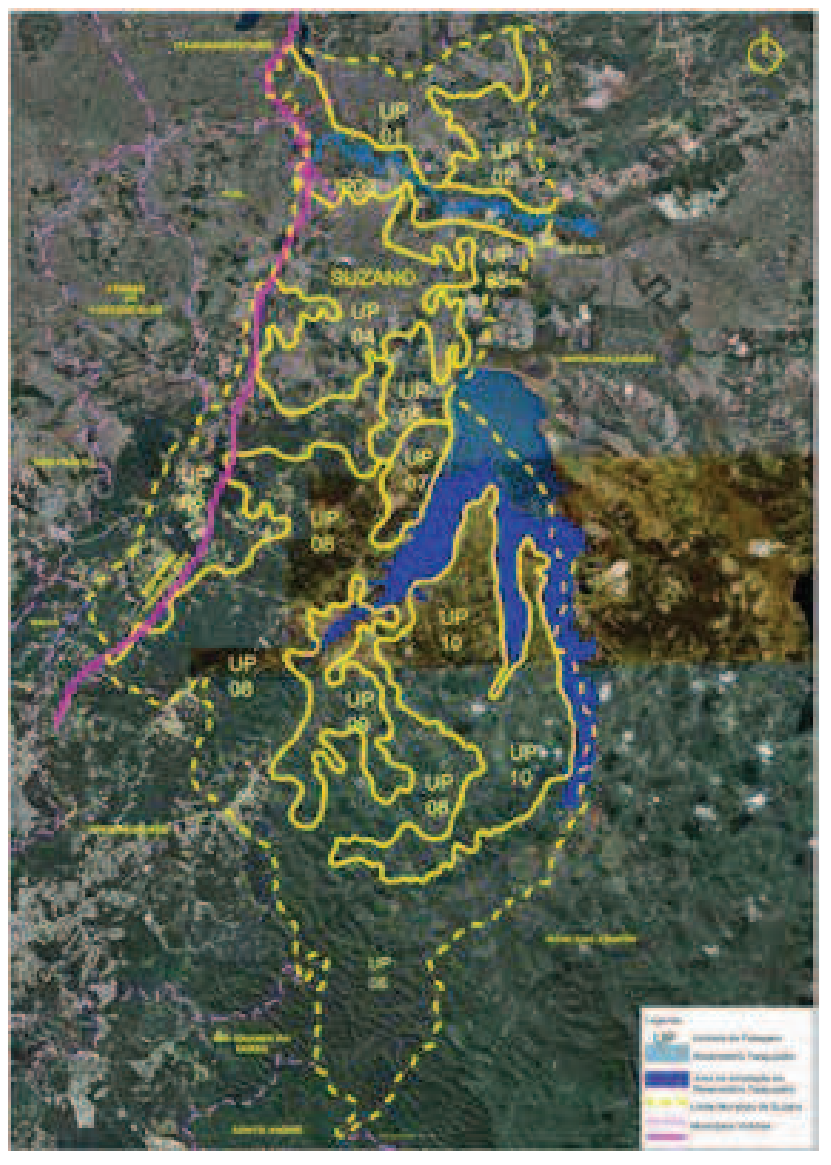

Figura 27 Mapa criado por Michele de Sá Vieira e Sanderlei Fernandes Vilanova - 2011. Fonte: Google. Acesso em: dez. 2011. 


\section{UNIDADES DE PAISAGEM: USO E OCUPAÇÃO DO SOLO}

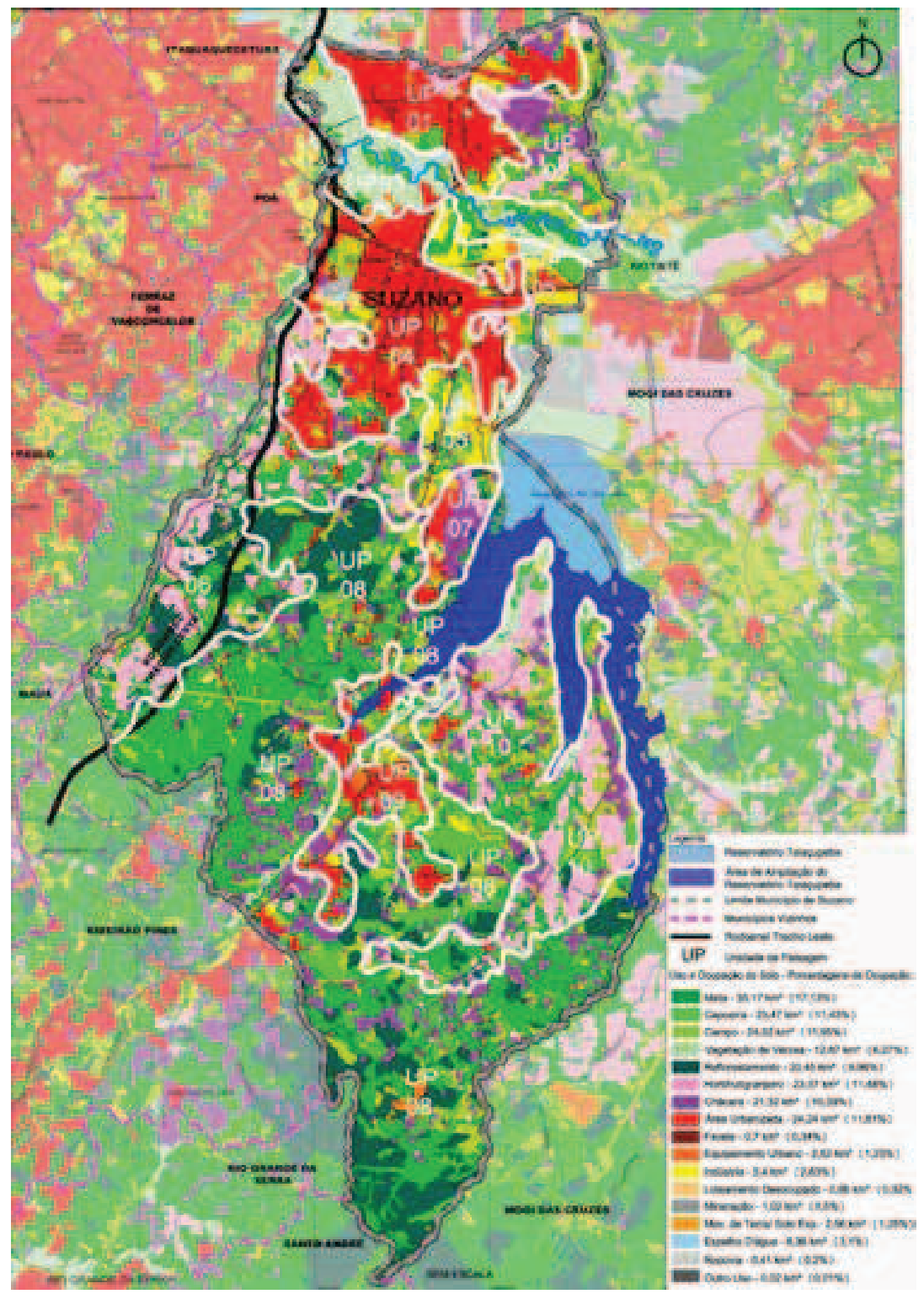

Figura 28 Mapa criado por Michele de Sá Vieira e Sanderlei Fernandes Vilanova - 2011. Fonte: Mapa do Uso e Ocupação do Solo da EMPLASA - 2006.

\section{UNIDADES DE PAISAGENS}

\section{UNIDADE DE PAISAGEM 01}

\section{CARACTERÍSTICAS}

Possui urbanização consolidada e alta multiplicidade de usos. Implantada em parte sobre relevo plano, mas também inclinado, tem como característica principal, no que se refere ao uso e ocupação do solo, a existência de muitos loteamentos altamente ocupados - sendo que parte deles está dentro da várzea do Tietê - além de baixa concentração de indústrias, plantações de hortifrutigranjeiros, chácaras, fragmento de mata nativa, capoeiras e campos. Com relação aos espaços livres, possui parque e praças não urbanizados. 


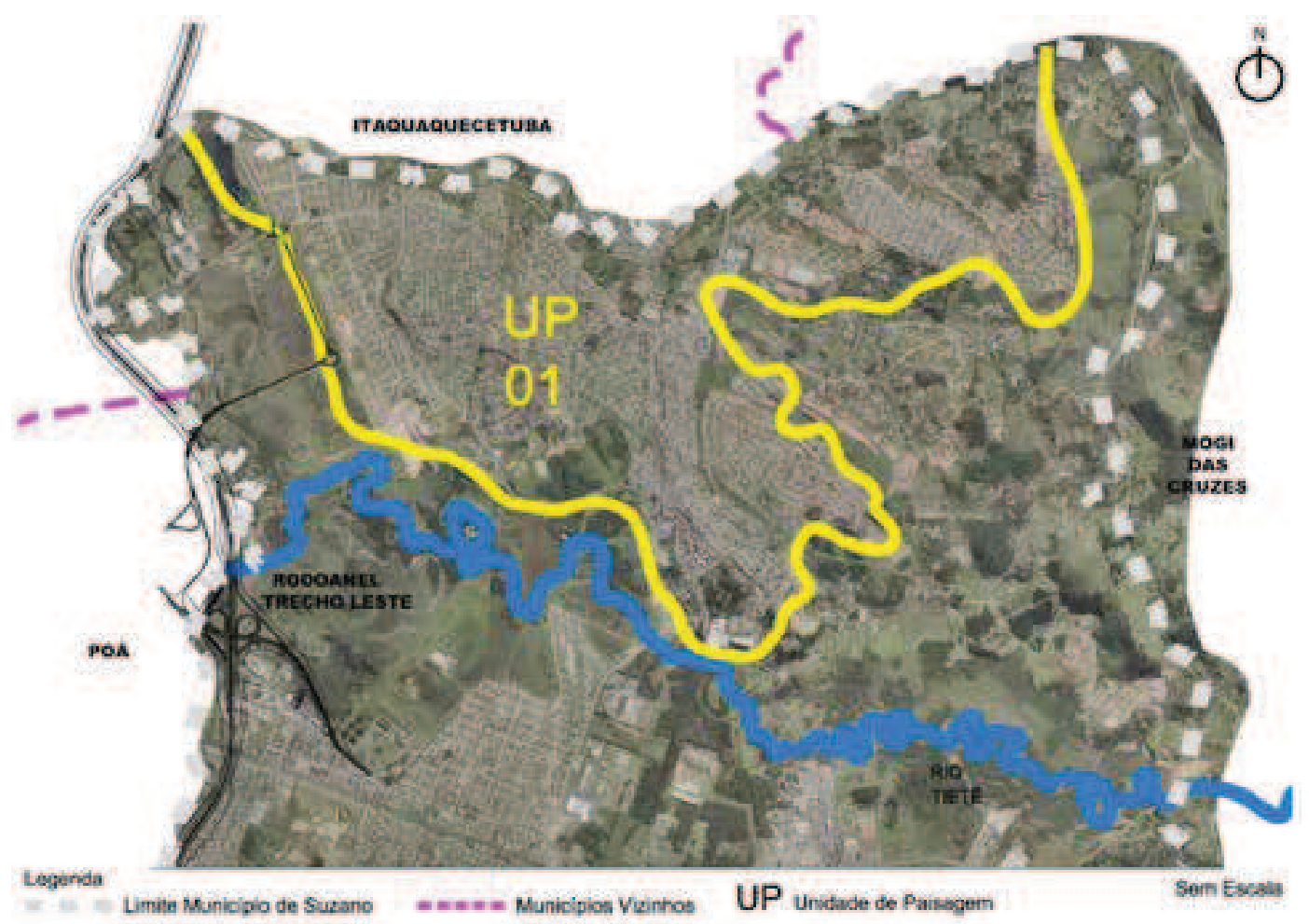

Figura 29 Suzano. Unidade de Paisagem 01.

Mapa criado por Michele de Sá Vieira e Sanderlei Fernandes Vilanova - 2012.

Fonte: Mapa aerofotogramétrico da PMS - 2008.

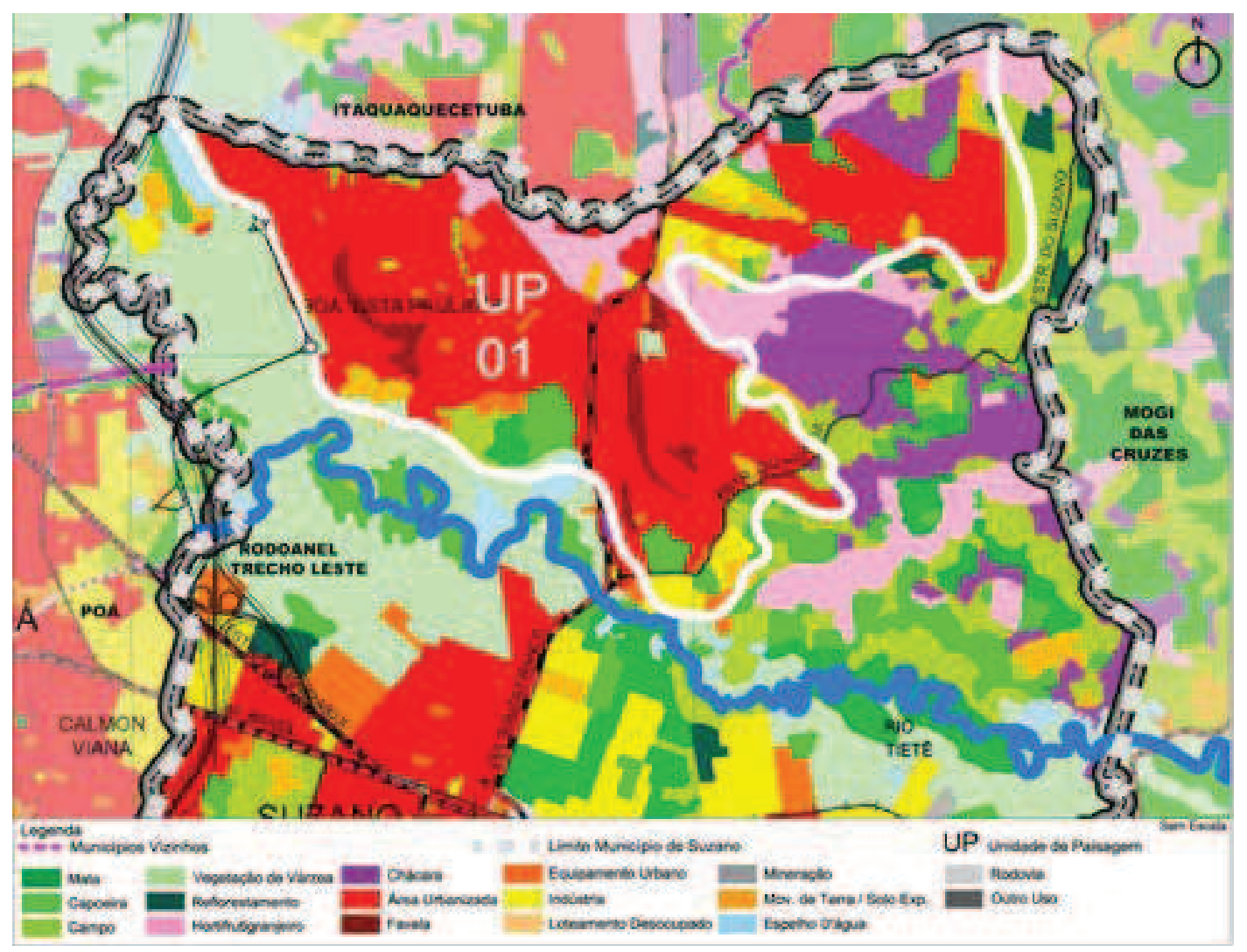

Figura 30 Suzano. Unidade de Paisagem 01.

Mapa criado por Michele de Sá Vieira e Sanderlei Fernandes Vilanova - 2012.

Fonte: Mapa do Uso e Ocupação do Solo da EMPLASA - 2006. 


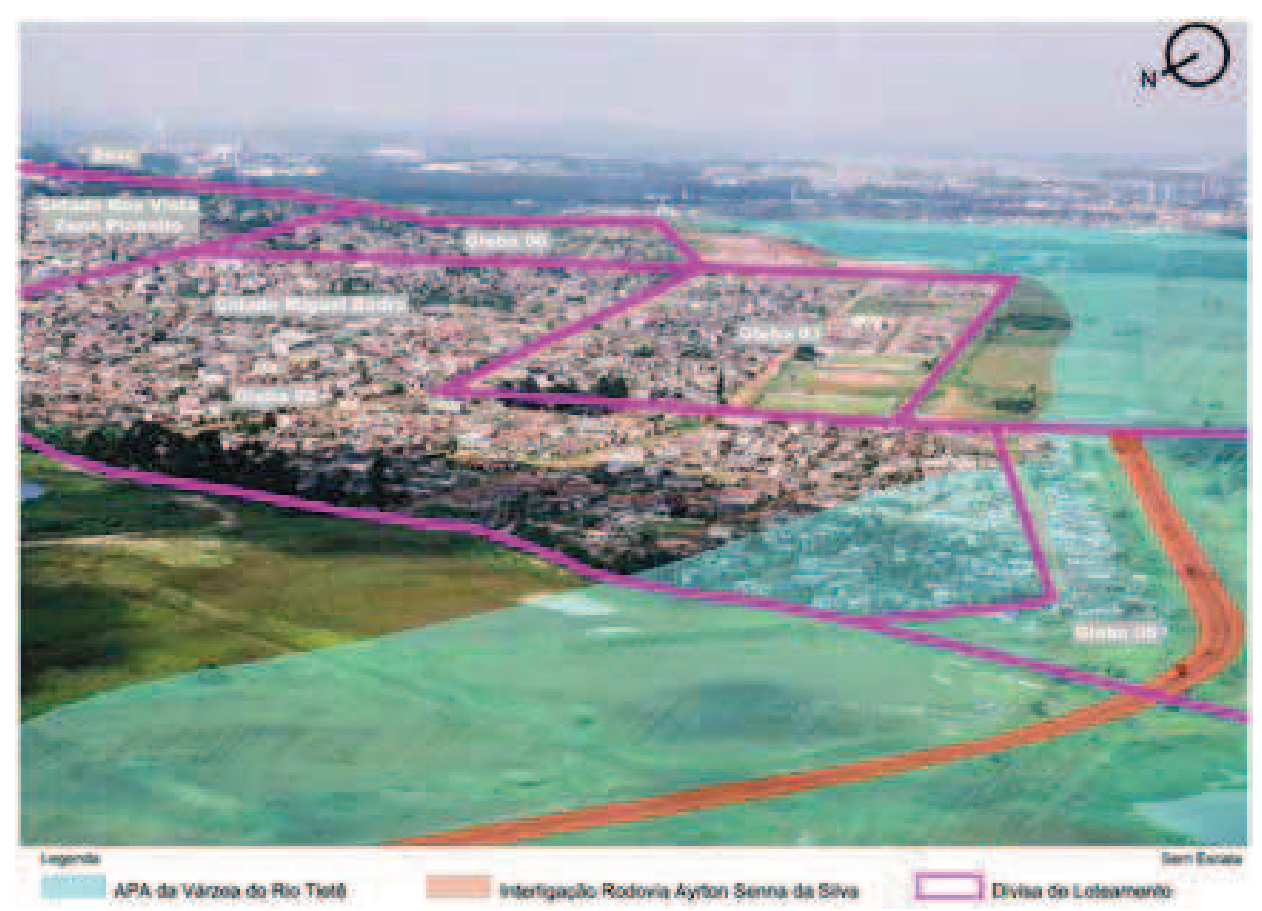

Figura 31 Suzano. Unidade de Paisagem 01. Loteamento Cidade Miguel Badra (Glebas 2, 3, 5 e 6). Implantado próximo à rodovia Ayrton Senna, sobre relevo praticamente plano, está altamente adensado por ocupações de baixa qualidade que se inserem ao lado e também dentro da APA da várzea do Tietê. A cidade, apesar de estar em um território com grande potencial para o lazer, pelos recursos que este possui em termos ambientais e paisagísticos - no caso, pelos estoques significativos de matas e pelas águas, represa, rios e riachos ainda limpos - não tem aproveitado tal potencial para a melhoria ou incremento de seu sistema de espaços livres e de sua paisagem urbana em geral, sendo estes praticamente ignorados.

Imagem elaborada por Michele de Sá Vieira e Sanderlei Fernandes Vilanova - 2012.

Fonte: PMS - 2008.

\section{CONFLITOS}

A urbanização local, expressa por intenso adensamento populacional, com paisagens altamente antropizadas e ocupações irregulares em arruamentos geralmente não malfeitos, com excessiva ocupação dos lotes, ausência de calçamento e escassez de espaços livres públicos tratados e privados que, em parte, estão em áreas de várzea expressas por baixíssima qualidade estética e urbanística, causa um conflito latente e promove fortes e agressivas transformações no suporte físico e erradicação total ou parcial de vegetação.

Existem ainda conflitos relacionados à ausência da convivência da sociedade com um dos espaços livres mais significativos do território, a várzea do Tietê, às constantes movimentações de terra, permitindo a exposição do solo, além das queimadas que acontecem no parque Mirante do Tietê, provocadas muitas vezes pela própria população que vive em seu entorno.

\section{CENÁRIOS FUTUROS POSSÍVEIS}

No que se refere aos cenários futuros possíveis positivos, a proximidade das ocupações junto à várzea do Tietê pode possibilitar ampla convivência da população com esta área 
a partir da implementação do parque Várzeas do Tietê, sem dúvida, uma das grandes oportunidades existentes no território com relação aos espaços livres.

Apesar dos inúmeros conflitos existentes, esta unidade de paisagem possui qualidades para se desenvolver de forma a ter seus espaços transformados positivamente no que se refere aos aspectos urbanísticos e ambientais.

Uma das oportunidades está vinculada aos canteiros centrais de algumas ruas, como a Edmilson Rodrigues Marcelino, que, em função das suas amplas extensões, podem ser transformados em ciclovias, além de abrigar espaços de lazer, bem-estar e arborização urbana.

Outras áreas existem com potencial para o uso público, como o rico sistema hídrico capaz de abrigar parques lineares, a exemplo do córrego Jaguari e as áreas de praças, que, se forem tratadas, poderão atender as demandas da população e compor o sistema de espaços livres públicos.

$\bigcirc$ parque Mirante do Tietê, mais um grande potencial existente nesta unidade de paisagem, apesar de não possuir característica alguma voltada às atividades de parque, pode tornar-se uma excelente opção, pois contém amplas áreas, que podem ser destinadas à instalação de equipamentos, vegetação nativa e proximidade com a várzea do Tietê.

No entanto, ainda que este parque se apresente como um grande cenário futuro positivo, seu solo está bastante degradado, já que abriga intensa quantidade de resíduos da construção civil. A tendência é que este volume se amplie, dado ao fato de o local possuir extensas áreas com capacidade para receber um número maior de materiais desta natureza.

A consolidação das ocupações irregulares é outro fato presente nesta unidade, pois, em função de sua extensão e conformação, acabam por se tornar espaços suscetíveis à invasão para a construção de locais precários de moradia pela população de baixa renda, impossibilitada de alugar ou adquirir propriedades regulares, ocupando as áreas de maneira inadequada.

\section{UNIDADE DE PAISAGEM 02}

\section{CARACTERÍSTICAS}

Possui urbanização incipiente, amplas e extensas propriedades de chácaras e hortifrutigranjeiros cercadas por áreas de campos, matas, capoeiras e reflorestamentos, sobre relevo em geral acidentado e que ainda apresenta alguns trechos planos. Com relação aos espaços livres públicos, possui praças não urbanizadas; faz fronteira com a APA da várzea do rio Tietê; contém parte da serra do Itapety e não possui parques.

\section{CONFLITOS}

Assim como na Unidade de Paisagem 01, esta também possui movimentação de terra com solo exposto e exploração do sistema hídrico em função das atividades vinculadas à agricultura, e baixa qualidade em relação aos aspectos urbanísticos. 


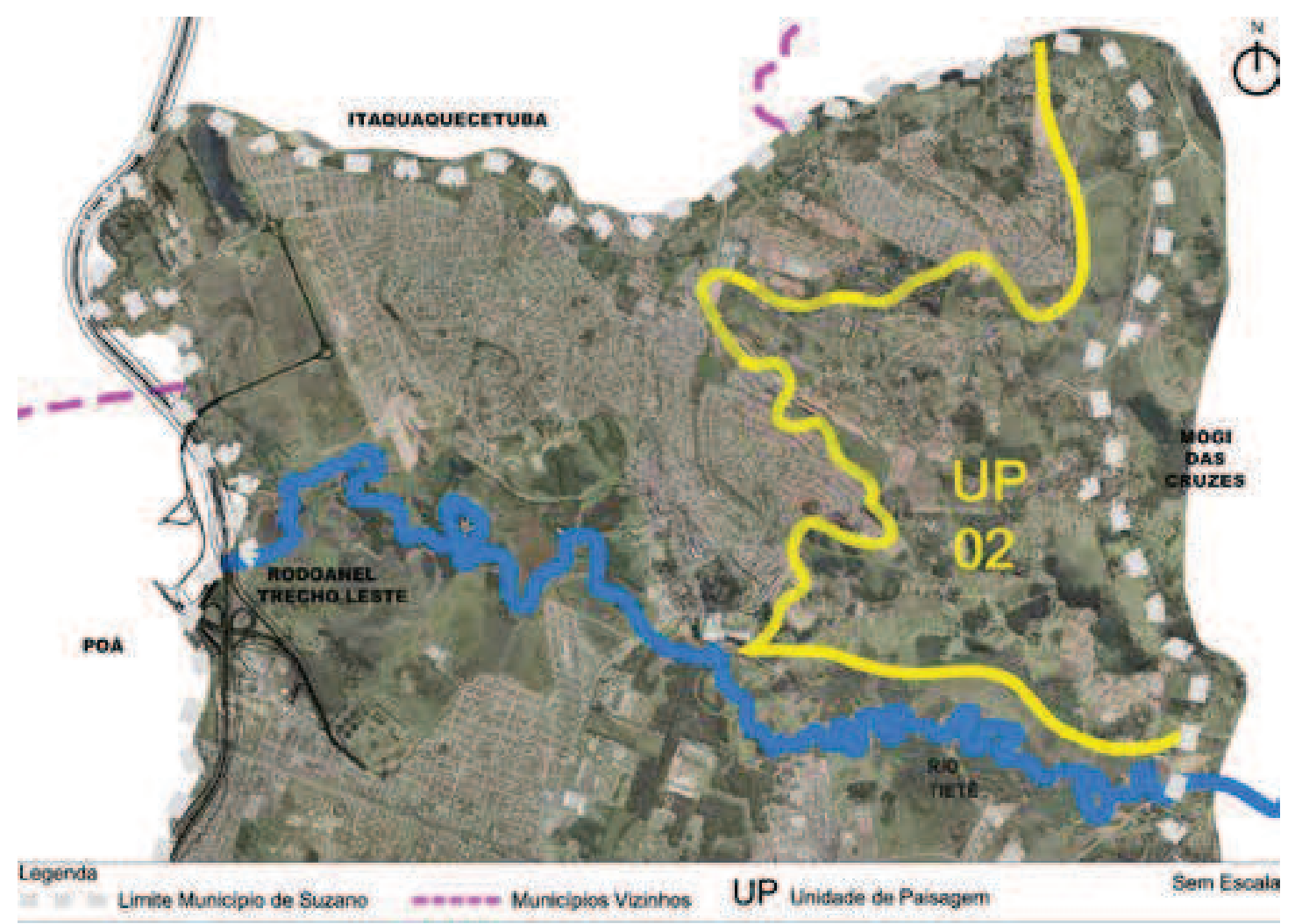

Figura 32 Suzano. Unidade de Paisagem 02.

Mapa criado por Michele de Sá Vieira e Sanderlei Fernandes Vilanova - 2012.

Fonte: Mapa aerofotogramétrico - PMS - 2008.

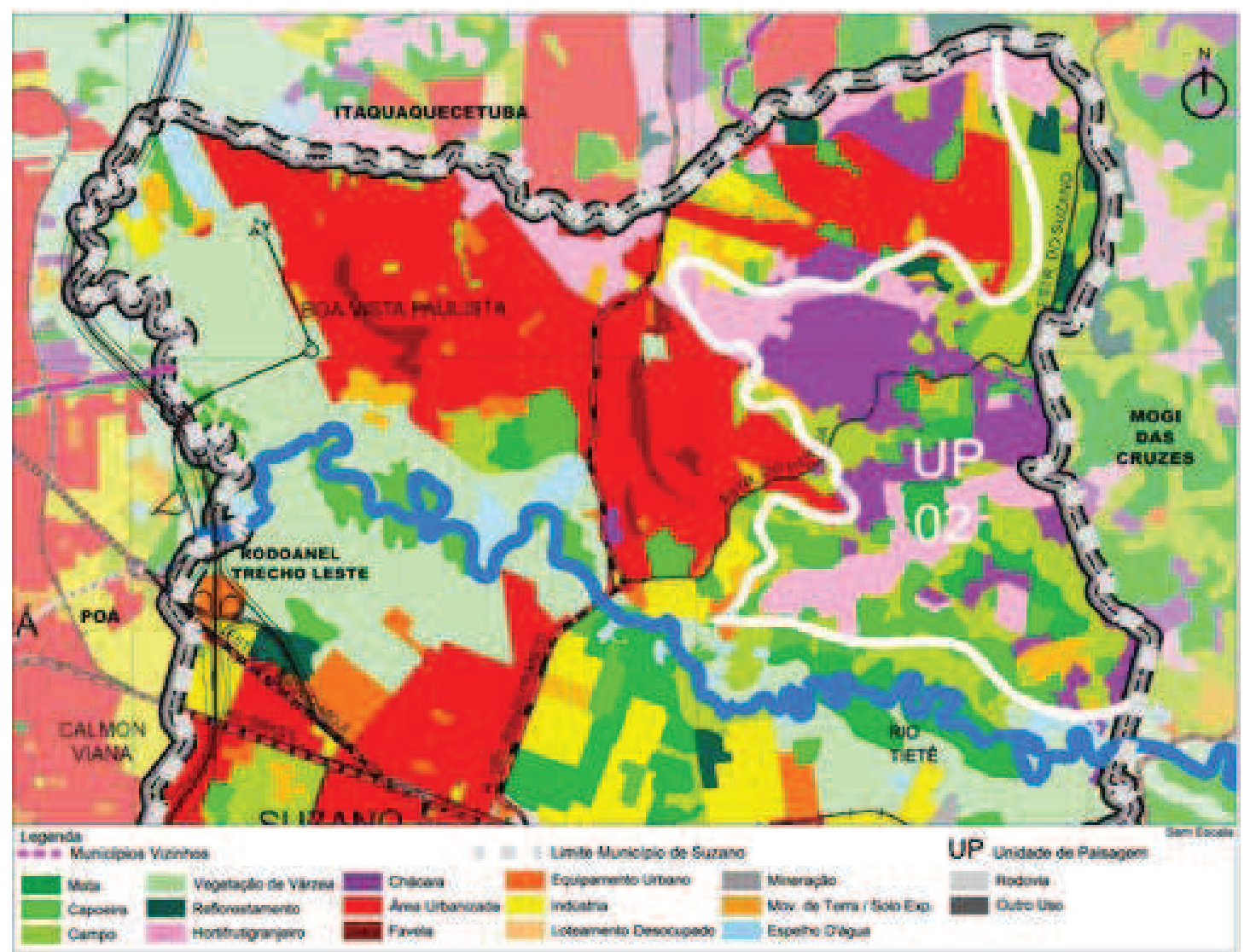

Figura 33 Suzano. Unidade de Paisagem 02.

Mapa criado por Michele de Sá Vieira e Sanderlei Fernandes Vilanova - 2012.

Fonte: Mapa do Uso e Ocupação do Solo - EMPLASA - 2006. 


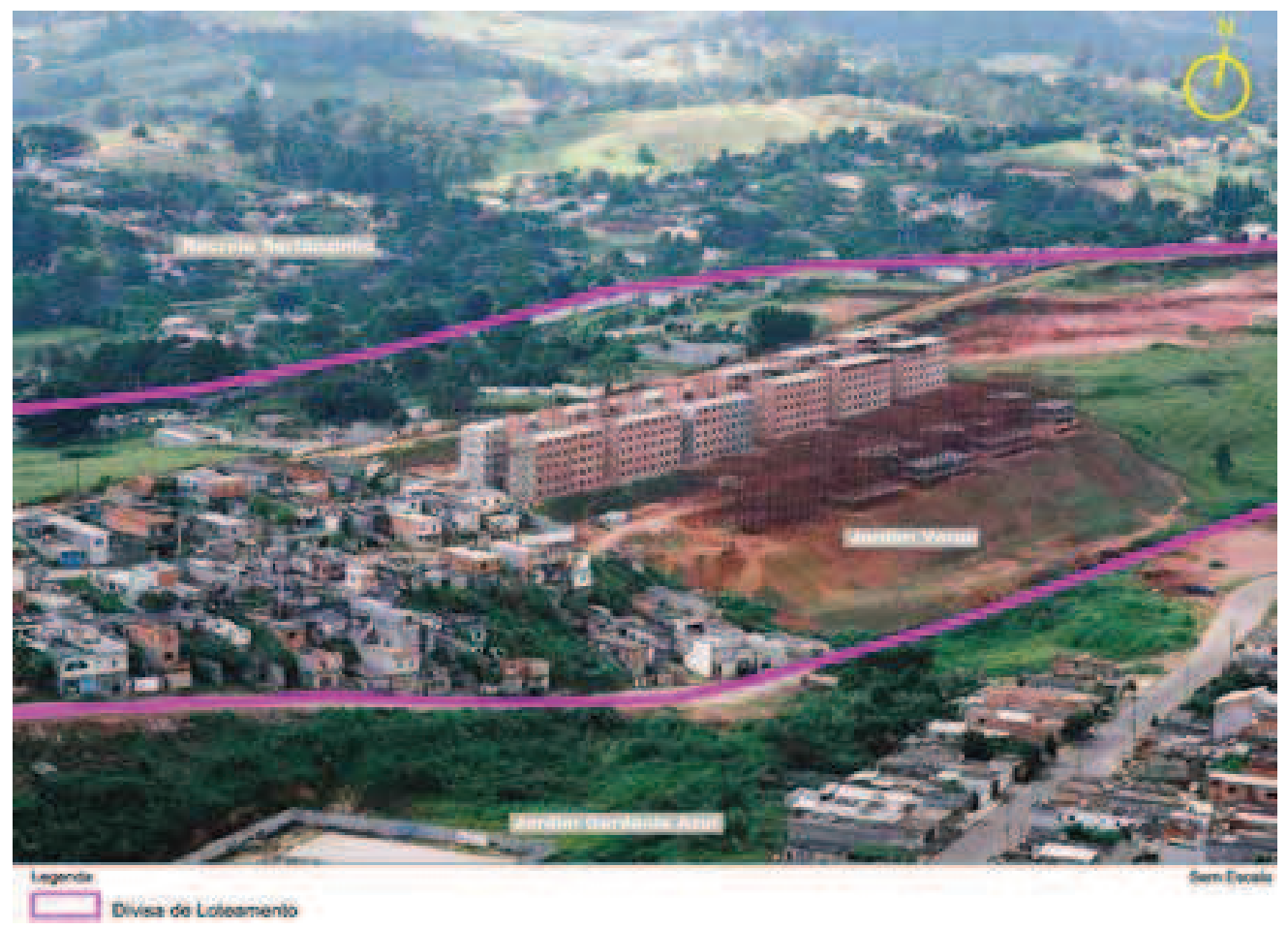

Figura 34 Suzano. Unidade de Paisagem 02. Nesta unidade de paisagem, que contém os loteamentos Recreio Sertãozinho, Jardim Varan e Jardim Gardênia Azul, observa-se o uso bastante diversificado do solo, através de ocupações unifamiliares precárias, unidades habitacionais, além de fragmentos de mata nativa preservados. Fonte: Mapa criado por Michele de Sá Vieira e Sanderlei Fernandes Vilanova - 2012.

Fonte: Mapa do Uso e Ocupação do Solo - EMPLASA - 2006.

\section{CONFLITOS}

Assim como na Unidade de Paisagem 01, esta também possui movimentação de terra com solo exposto e exploração do sistema hídrico em função das atividades vinculadas à agricultura, e baixa qualidade em relação aos aspectos urbanísticos.

\section{CENÁRIOS FUTUROS POSSÍVEIS}

Como cenário futuro positivo, há a possibilidade de esta unidade estabelecer duas conexões com vegetação nativa através de corredores ecológicos: uma com a serra do Itapety, localizada no município de Mogi das Cruzes, e a outra com a várzea do rio Tietê.

A conexão com a serra do ltapety pode ser facilitada em função de dois aspectos:

- pelo fato de a serra estar bastante próxima do município de Suzano;

- em função de este território possuir, na Unidade de Paisagem 02, muitas áreas de campo e capoeira que podem ser reflorestadas, constituindo-se, portanto, em corredores ecológicos com capacidade de promover conexões com a serra.

Já com a várzea do Tietê a possibilidade se dá em razão:

- da proximidade com a própria várzea; 
- dos inúmeros fragmentos existentes tanto na várzea, quanto na Unidade de Paisagem 02.

Como cenário futuro negativo, a consolidação das ocupações irregulares é uma questão presente nesta unidade, assim como na unidade anterior, em função do preço da terra ser conveniente à população que apresenta baixa renda.

\section{UNIDADE DE PAISAGEM 03}

\section{CARACTERÍSTICAS}

É constituída em 2012 pela APA da várzea do rio Tietê. Instalada em relevo plano, possui urbanização incipiente, alto potencial estético e, embora esteja parcialmente antropizada, em função da concentração de indústrias e demais ocupações, trata-se de uma área com expressivo interesse ecológico, ambiental e paisagístico, possuindo meandros e fragmentos de mata ao longo do rio bem preservados, além de extensas áreas cobertas por campo e capoeira.

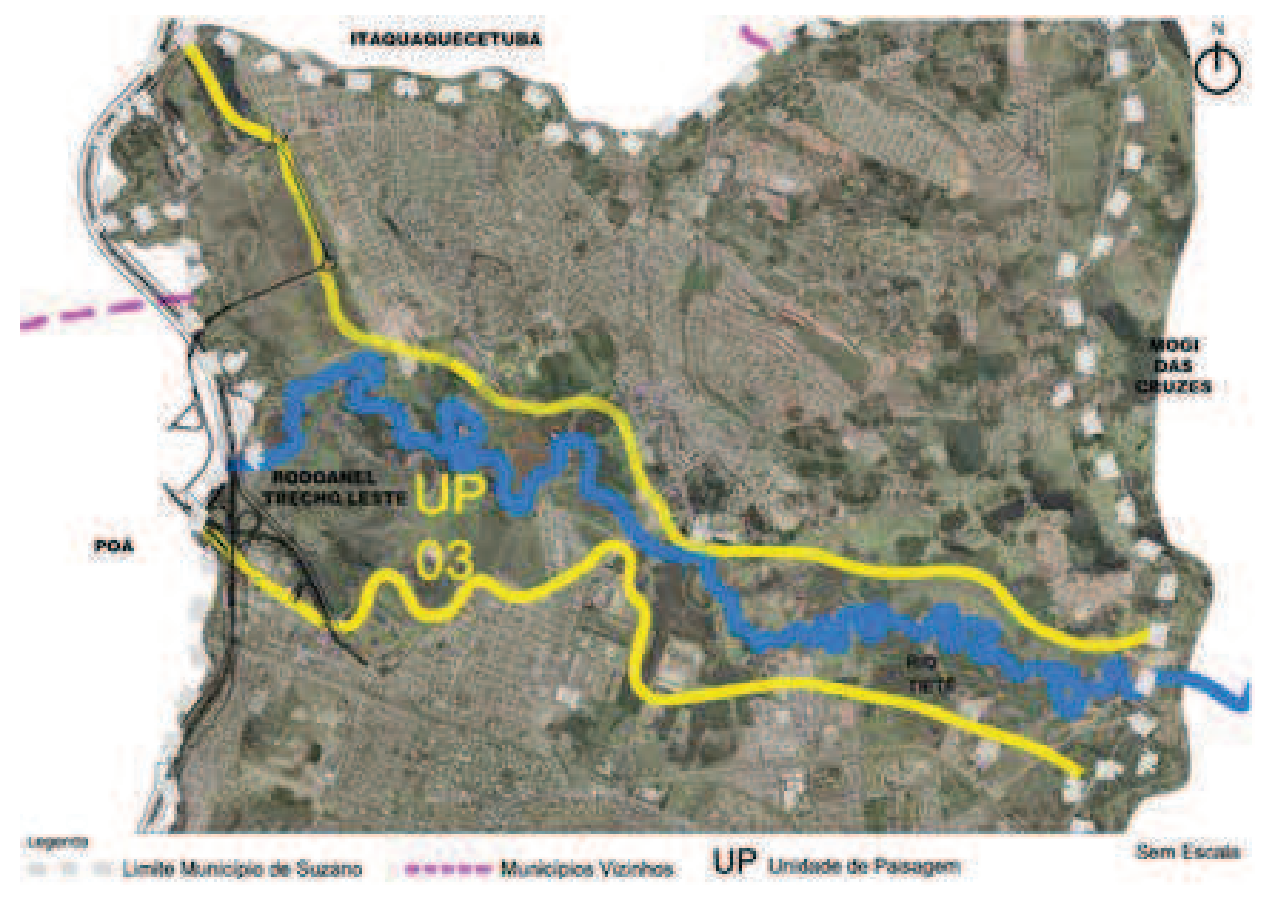

Figura 35 Suzano. Unidade de Paisagem 03.

Fonte: Mapa criado por Michele de Sá Vieira e Sanderlei Fernandes Vilanova - 2012.

Fonte: Mapa aerofotogramétrico da PMS - 2008.

\section{CONFLITOS}

Ainda que esta unidade de paisagem possua intenso potencial paisagístico, ambiental e ecológico, nela estão assentados equipamentos industriais e o Centro de Detenção Provisória (CDP), além de outras atividades já licenciadas com previsão de exploração, vinculadas à extração mineral com concessão de lavra, argila e cascalho. 
Dentre todas as ações conflitantes existentes nesta unidade, a mais significativa refere-se ao fato de alguns loteamentos, como a Vila Maluf, se situarem sobre a área da várzea, sofrendo várias inundações.

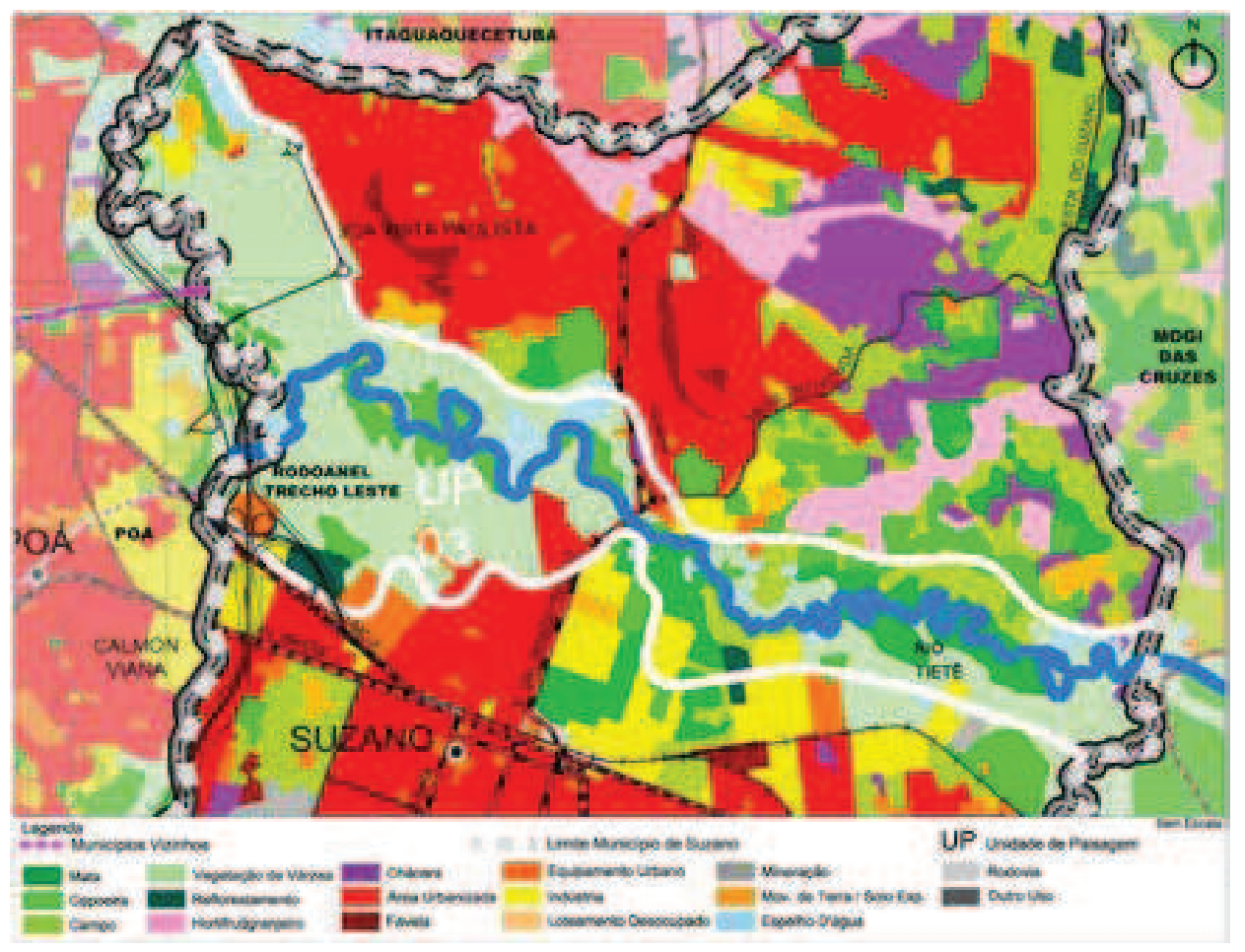

Figura 36 Suzano. Unidade de Paisagem 03.

Fonte: Mapa criado por Michele de Sá Vieira e Sanderlei Fernandes Vilanova - 2012. Fonte: Mapa do Uso e Ocupação do Solo - EMPLASA - 2006.

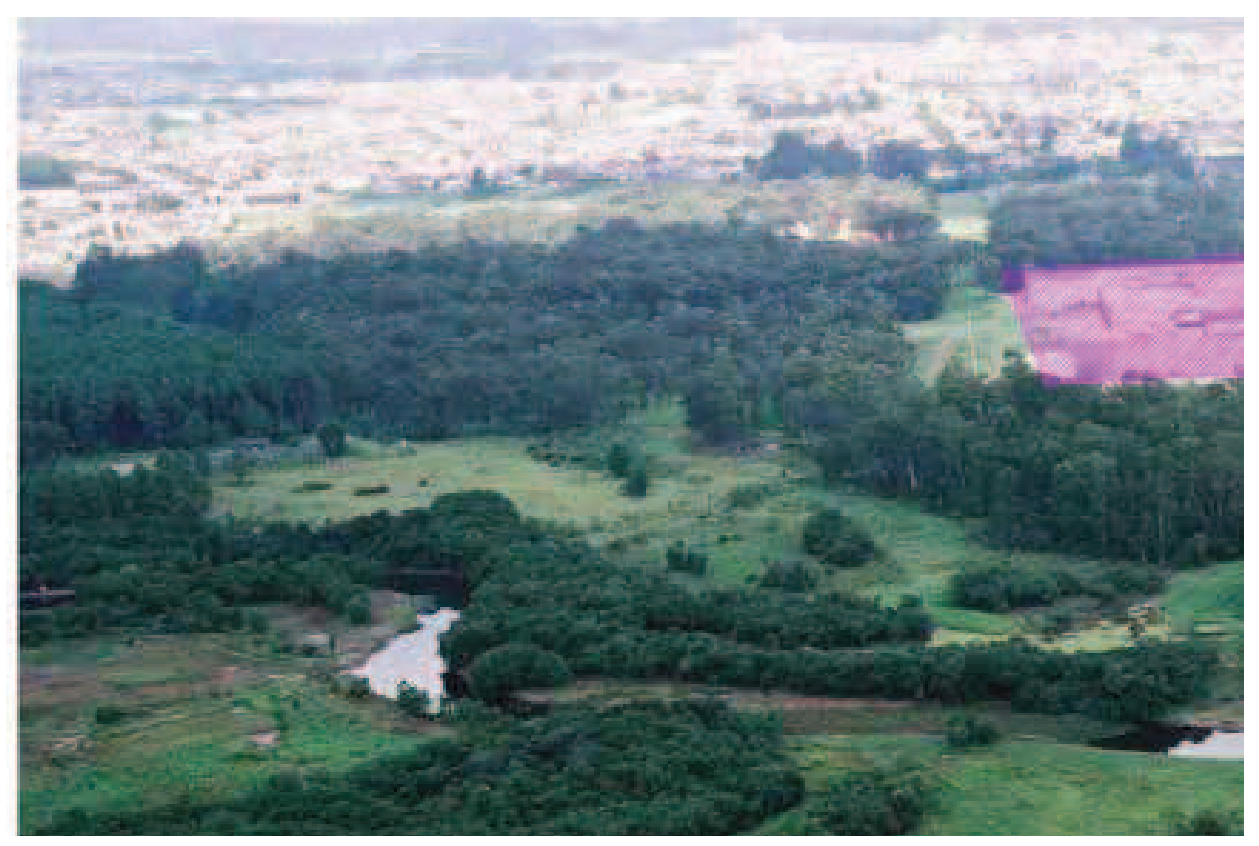

Figura 37 Suzano. Unidade de Paisagem 03. A beleza cênica da APA da várzea do Tietê é evidente. No entanto, ações antrópicas como a instalação do Centro de Detenção Provisória (CDP) comprometem a estética da paisagem, bem como a integridade física do ambiente.

Imagem organizada por Michele de Sá Vieira e Sanderlei Fernandes Vilanova - 2012.

Fonte: PMS - 2008. 


\section{CENÁRIOS FUTUROS POSSÍVEIS}

A implantação do parque Várzeas do Tietê, com alto potencial cênico, prevista pelo governo do Estado é, sem dúvida, o grande cenário futuro positivo a ser efetivado. Caso realmente aconteça, esta iniciativa, além de definir o uso adequado do espaço, vai oferecer possibilidades de convivência da população com a paisagem desta unidade.

Como cenário negativo observa-se que, caso o parque Várzeas não seja implantado, a tendência é que ocorra a extinção dos fragmentos de mata nativa em função das constantes ações antrópicas. Além disso, a ampliação total ou parcial de empreendimentos vinculados à indústria, a serem construídos, contribuirão significativamente para a ampliação da impermeabilização do solo.

Com relação às águas, a não execução de medidas voltadas ao tratamento de esgotos por parte da Sabesp tende a permitir a ampliação da polvição sanitária.

Para além das questões conflitantes já instaladas, existe a previsão da implantação da alça do Rodoanel Leste, que será construída sobre a várzea do Tietê.

\section{UNIDADE DE PAISAGEM 04}

\section{CARACTERÍSTICAS}

Possui ocupações urbanas consolidadas, situadas sobre relevo principalmente plano, servidas de infraestrutura relacionada ao saneamento básico, iluminação, pavimentação, transporte, espaços livres com usos definidos, além de equipamentos urbanos voltados à educação e saúde.

De maneira menos preponderante, no que se refere ao uso e a ocupação do solo, esta unidade de paisagem possui loteamentos desocupados, espaços destinados à indústria, áreas de campos, capoeiras, matas, chácaras e cultivo de hortifrutigranjeiros.

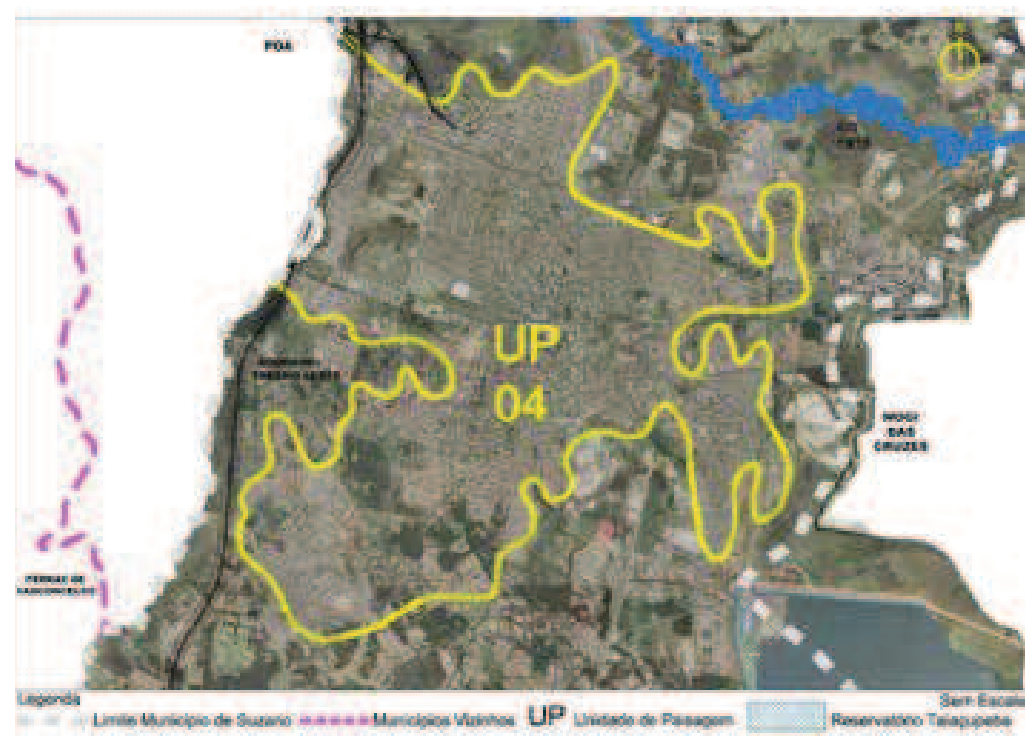

Figura 38 Suzano. Unidade de Paisagem 04.

Mapa criado por Michele de Sá Vieira e Sanderlei Fernandes Vilanova - 2012.

Fonte: Mapa aerofotogramétrico da PMS - 2008. 


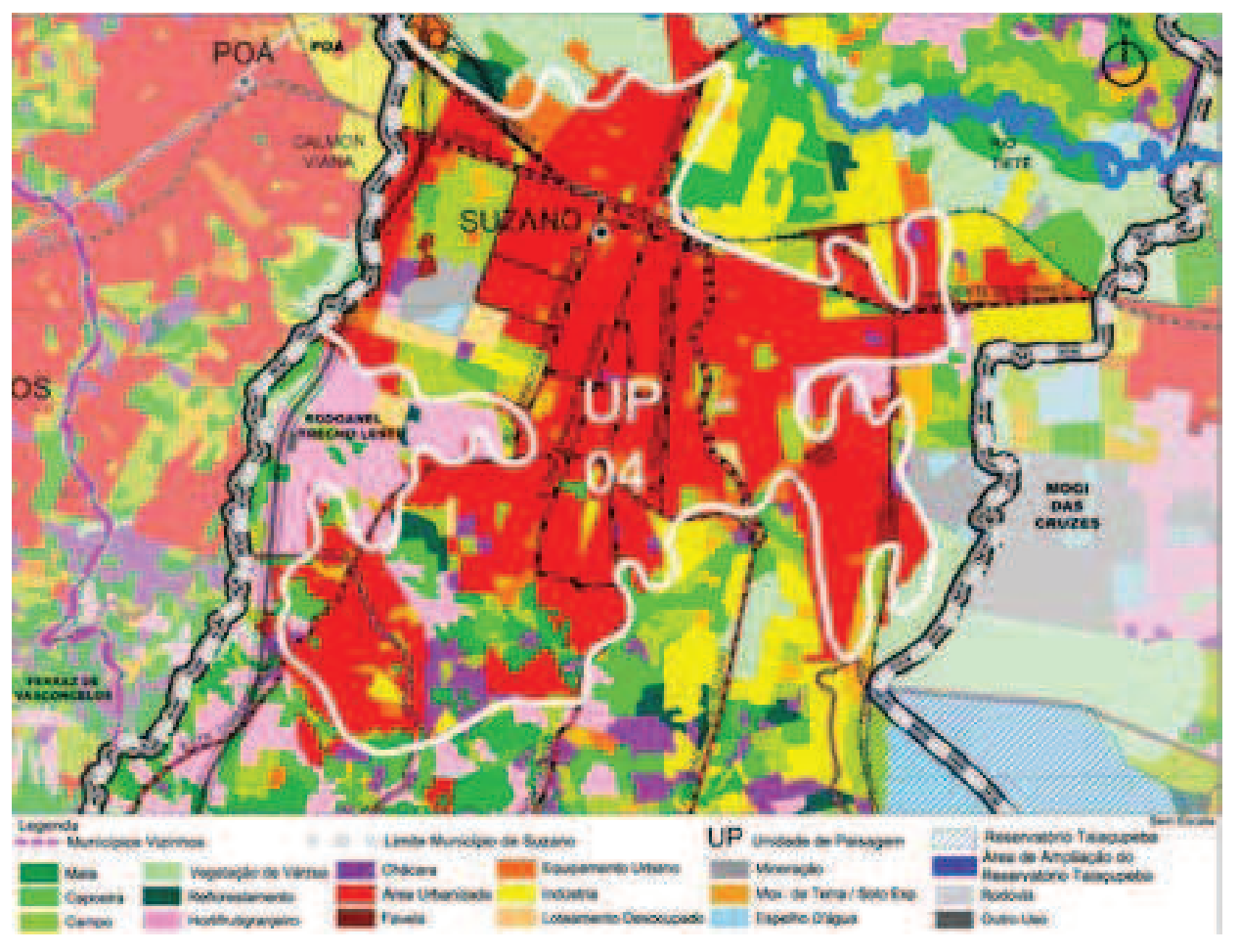

Figura 39 Suzano. Unidade de Paisagem 04.

Mapa criado por Michele de Sá Vieira e Sanderlei Fernandes Vilanova - 2012.

Fonte: Mapa do Uso e Ocupação do Solo EMPLASA - 2006.

\section{CONFLITOS}

A exploração imobiliária latente sem dúvida contribuiu imensamente para os conflitos cada vez mais enfáticos ao longo dos anos nesta unidade de paisagem. Quando associamos as altas taxas de ocupação provenientes desta exploração - que geram impermeabilização do solo - ao sistema de drenagem público deficiente, temos como resultado as constantes enchentes no período de chuvas em determinados espaços desta região.

Além disso, outras questões são apontadas como conflitos:

- $\quad$ as calçadas inadequadas: por possuírem dimensões insuficientes, revestimentos danificados, ausência de pisos táteis que facilitem a mobilidade dos deficientes visuais, inexistência de rampas para as pessoas de mobilidade reduzida e arborização com raízes agressivas, que dificultam e até mesmo impedem o trânsito dos pedestres;

- a poluição visual das fachadas do comércio, que se encontram deterioradas devido à falta de manutenção por parte dos comerciantes, prejudicam a estética do centro comercial da cidade.

\section{CENÁRIOS FUTUROS POSSÍVEIS}

Como potencialidade positiva, apesar de diversas calçadas possuírem dimensões reduzidas, ainda assim existem muitas possibilidades para que a arborização urbana 
seja implementada na Unidade de Paisagem 04, favorecendo esteticamente os espaços e contribuindo para a regulação climática.

A Parada Tiradentes, obra implantada como projeto piloto em 2005, é um exemplo que promoveu diversas alterações que beneficiaram o espaço onde a intervenção aconteceu - no que se refere aos aspectos urbanísticos, paisagísticos e ambientais -, devido à inserção de pisos permeáveis, implementação de pisos táteis, rampas de acessibilidade, canteiro ajardinado junto às guias, inserção de espécies arbóreas e ornamentais, além de ponto de ônibus capaz de atender as demandas da população.
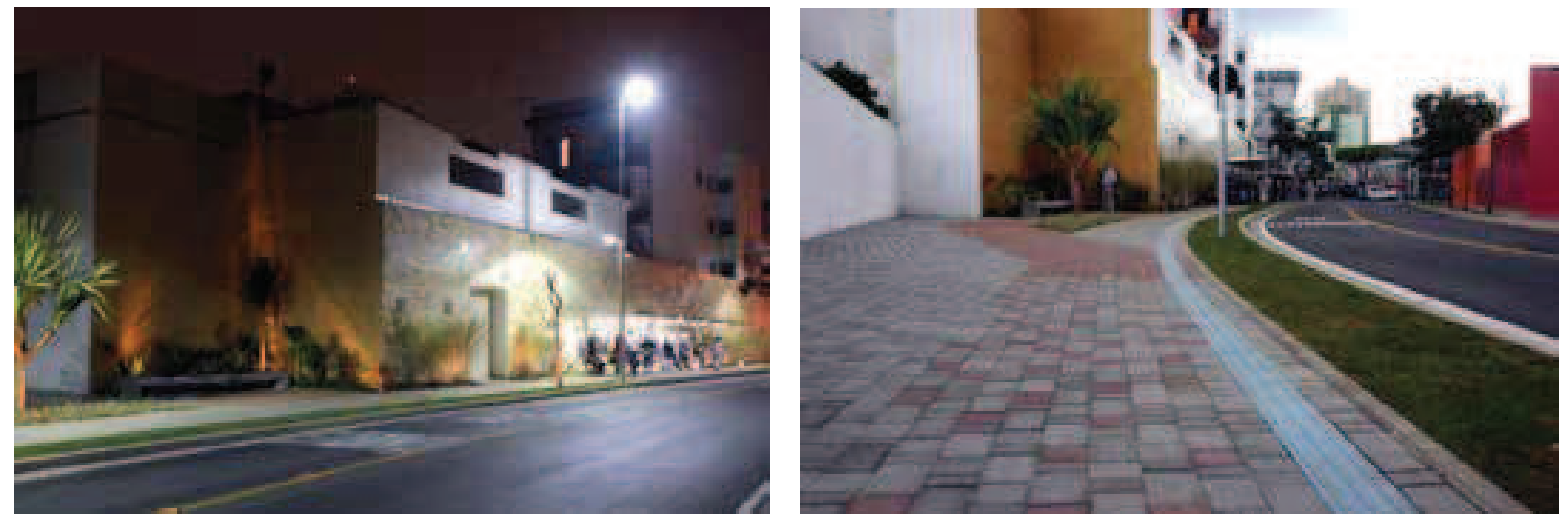

Figuras 40A e 40B Suzano. A Parada Tiradentes trouxe várias melhorias para o local. Nela o ponto de ônibus foi ampliado, o que permitiu um número maior de pessoas abrigadas. Além disso, pisos táteis foram inseridos para auxiliar os deficientes visuais.

Fonte: Prefeitura Municipal de Suzano - 2006.
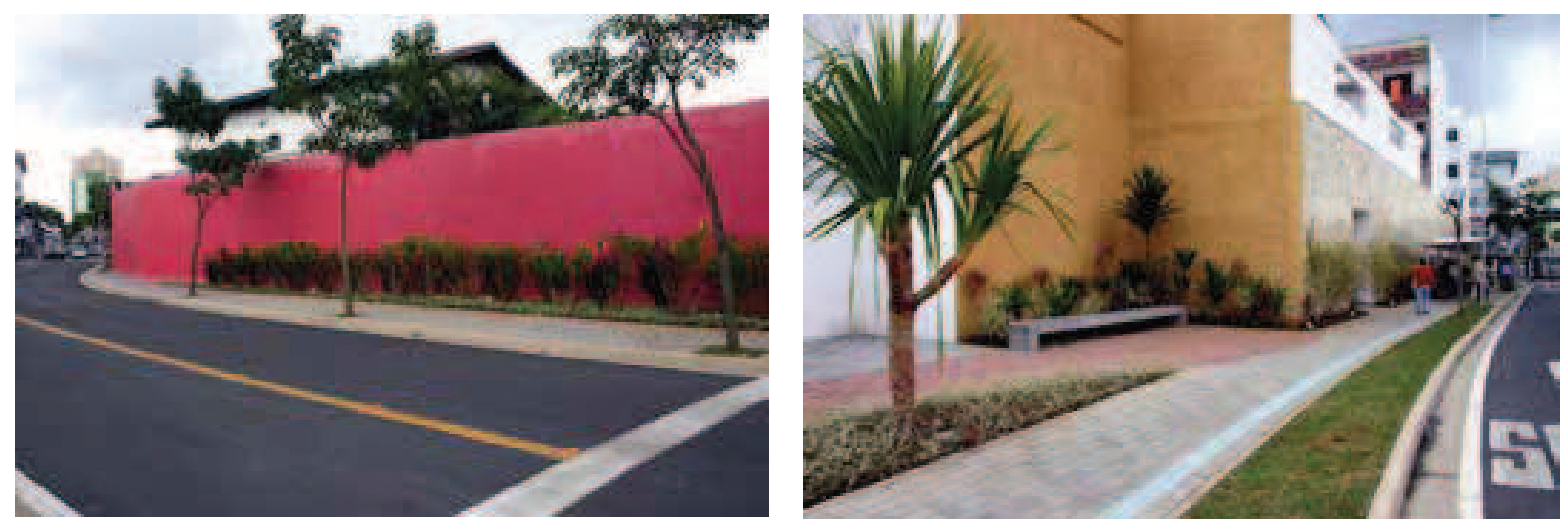

Figuras 41A e 41B Suzano. Outros aspectos ainda foram trabalhados na Parada Tiradentes, como a inserção de canteiros, valorizando o paisagismo no local e, consequentemente, o embelezamento da paisagem, além de um pequeno espaço voltado ao estar, para que a população pudesse permanecer no ambiente.

Fonte: Prefeitura Municipal de Suzano - 2006.

Para que cenários futuros com qualidade urbanística e paisagística aconteçam, projetos voltados à implementação de infraestrutura verde devem estar entre os objetivos da gestão pública.

A implementação de fragmentos florestais lineares também é outra ação possível para a região, considerando-se que há áreas remanescentes nesta unidade, capazes de receber diversas espécies de arborização. Um exemplo deste tipo de local está ao longo do córrego Chico da Vargem (rio Una), que possui espaços a serem utilizados 
tanto junto ao curso d'água quanto nos seus arredores, que podem ser incorporados a um grande desenho, com usos diversos, voltados ao lazer e à recreação.

A requalificação de algumas praças existentes através da inserção de novas espécies, novo mobiliário urbano e estímulo ao uso com atividades culturais, de lazer e recreação, também é uma ação possível para a potencialização dos espaços livres públicos na unidade.

Os principais eixos, como as ruas Francisco General Glicério e Benjamin Constant, oferecem oportunidades para serem fechados e transformados em calçadões capazes de conter arborização urbana, mobiliário urbano e iluminação, ou seja, ações que levem os cidadãos aos espaços externos, abertos, incentivando as atividades vinculadas ao comércio e ao lazer.

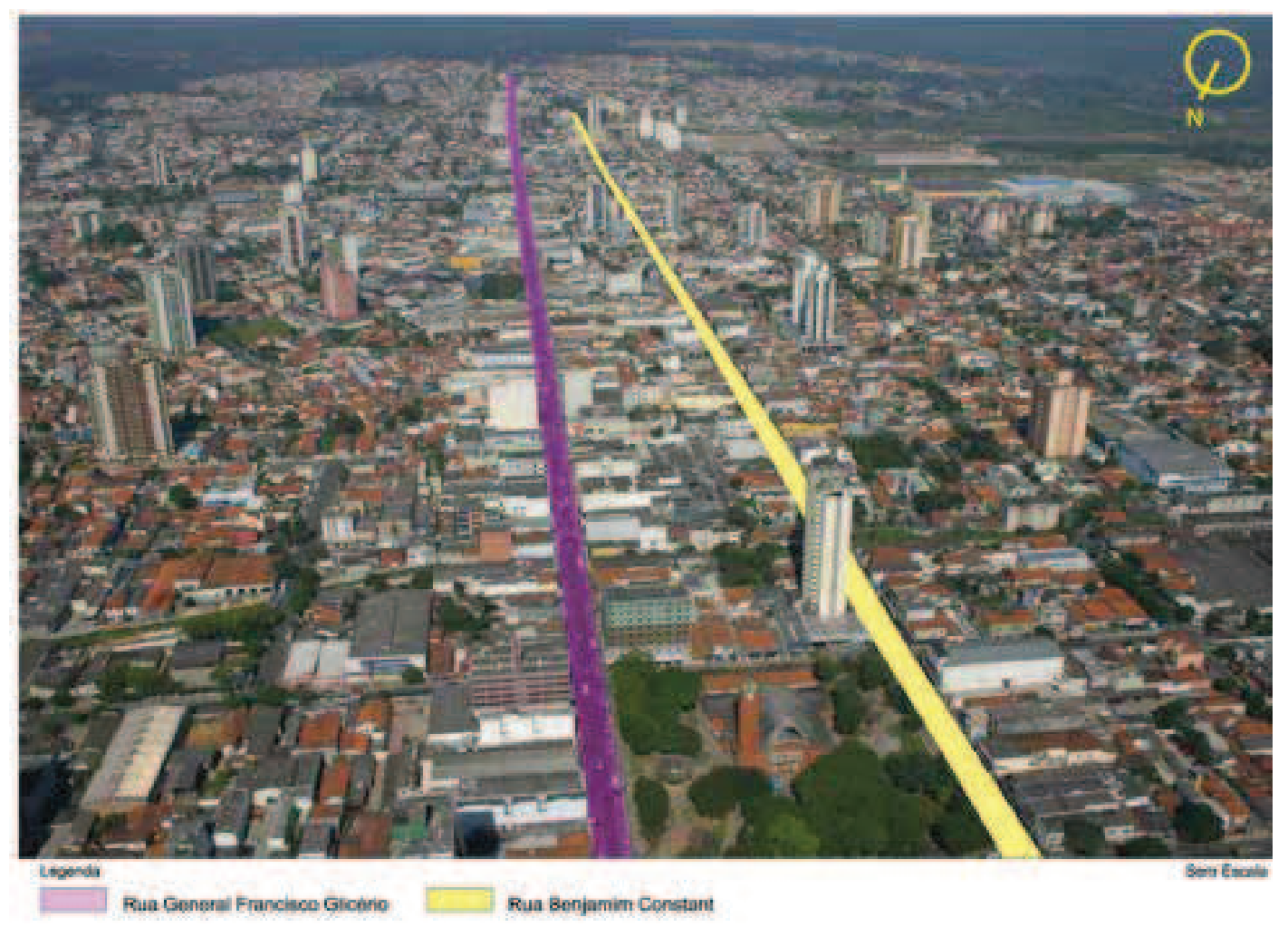

Figura 42 Suzano. Unidade de Paisagem 04. As ruas Francisco General Glicério e Benjamin Constant possuem comércio diversificado por conterem ao longo de seu percurso inúmeros bancos, farmácias, lanchonetes, restaurantes, além de lojas de eletrodomésticos, roupas, calçados, móveis, perfumaria, materiais de construção. Em função disso, e por serem eixos que promovem importantes interligações na região central, acabam atraindo inúmeros pedestres cotidianamente.

Imagem elaborada por Michele de Sá Vieira e Sanderlei Fernandes Vilanova - 2012.

Fonte: Prefeitura Municipal de Suzano - 2008.

Próximas ao parque Max Feffer, encontram-se as instalações do Instituto Federal de Educação, Ciência e Tecnologia de São Paulo (IFSP) e da Universidade Piaget (UniPiaget), que vão potencializar a região como um importante polo educacional. Ambos possuem amplos espaços livres que terão quadras de esporte entre outros equipamentos. No caso da UniPiaget será incorporada, especialmente, uma lagoa - antes utilizada como cava de mineração -, além de pista de corrida, ciclovia, quiosques e intenso plantio de espécies arbóreas, incrementando o sistema de espaços livres do território. 


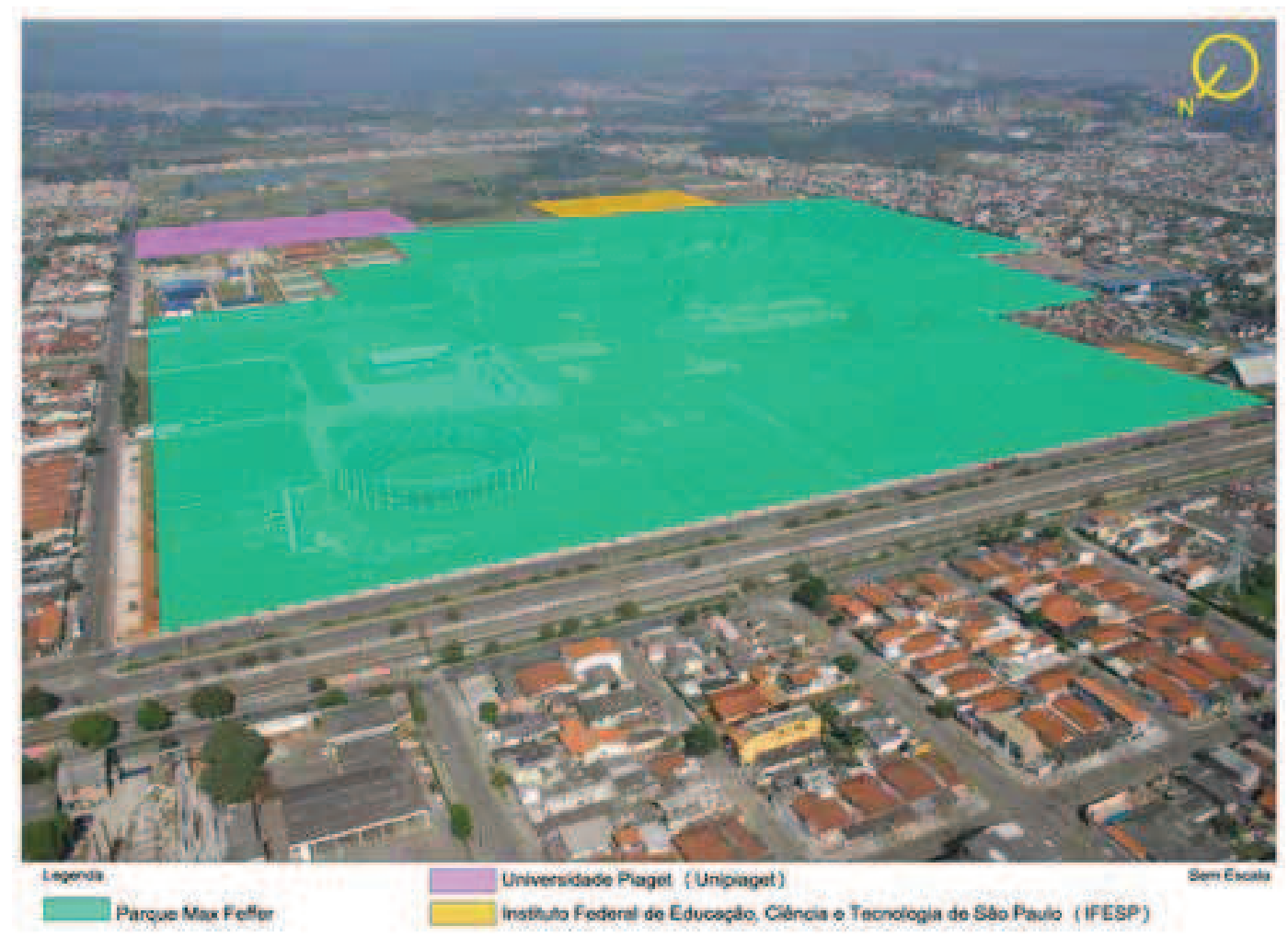

Figura 43 Suzano. Unidade de Paisagem 04.

A consolidação do Instituto Federal de Educação, Ciência e Tecnologia de São Paulo (IFSP) e da Universidade Piaget (UniPiaget), já edificados e com perspectivas de ampliação, somada à potencialização do parque Max Feffer, que vem recebendo inúmeras obras - como o pavilhão de cultura afro, a concha acústica, o pavilhão de esportes, a reforma da piscina, as obras em andamento da arena multiuso e da praça de apoio ao turista - sem dúvida trazem inúmeros benefícios para esta área, que já se encontra consolidada por ocupações urbanas servidas com boa infraestrutura de transporte, saneamento, iluminação, pavimentação.

Imagem elaborada por Michele de Sá Vieira e Sanderlei Fernandes Vilanova - 2012.

Fonte: PMS - 2008.

Como cenário futuro negativo observa-se que as inúmeras retiradas da vegetação arbórea da região central, somadas à ausência de reposição com novos indivíduos, tende a comprometer este setor no que se refere à temperatura e à estética local.

A dificuldade quanto à acessibilidade é outro fato negativo, dada à existência de calçadas estreitas, o que se soma à falta de iniciativas privadas em relação à manutenção e, por exemplo, à recuperação dos seus revestimentos.

\section{UNIDADE DE PAISAGEM 05}

\section{CARACTERÍSTICAS}

Possui urbanização consolidada, ocupada por grande área industrial assentada sobre relevo praticamente plano, abrigando importantes empresas de grande porte: Clariant S/A, Produquímica Indústria e Comércio Ltda., Agfa Graphics Brasil, Komatsu do Brasil, além da Suzano Papel e Celulose, maior empresa do município.

A vegetação é abundante nesta unidade, a qual contém áreas de várzea próximas à represa de Taiaçupeba, bem como campos, capoeiras e mata nativa entremeados, próximos às ocupações industriais. 


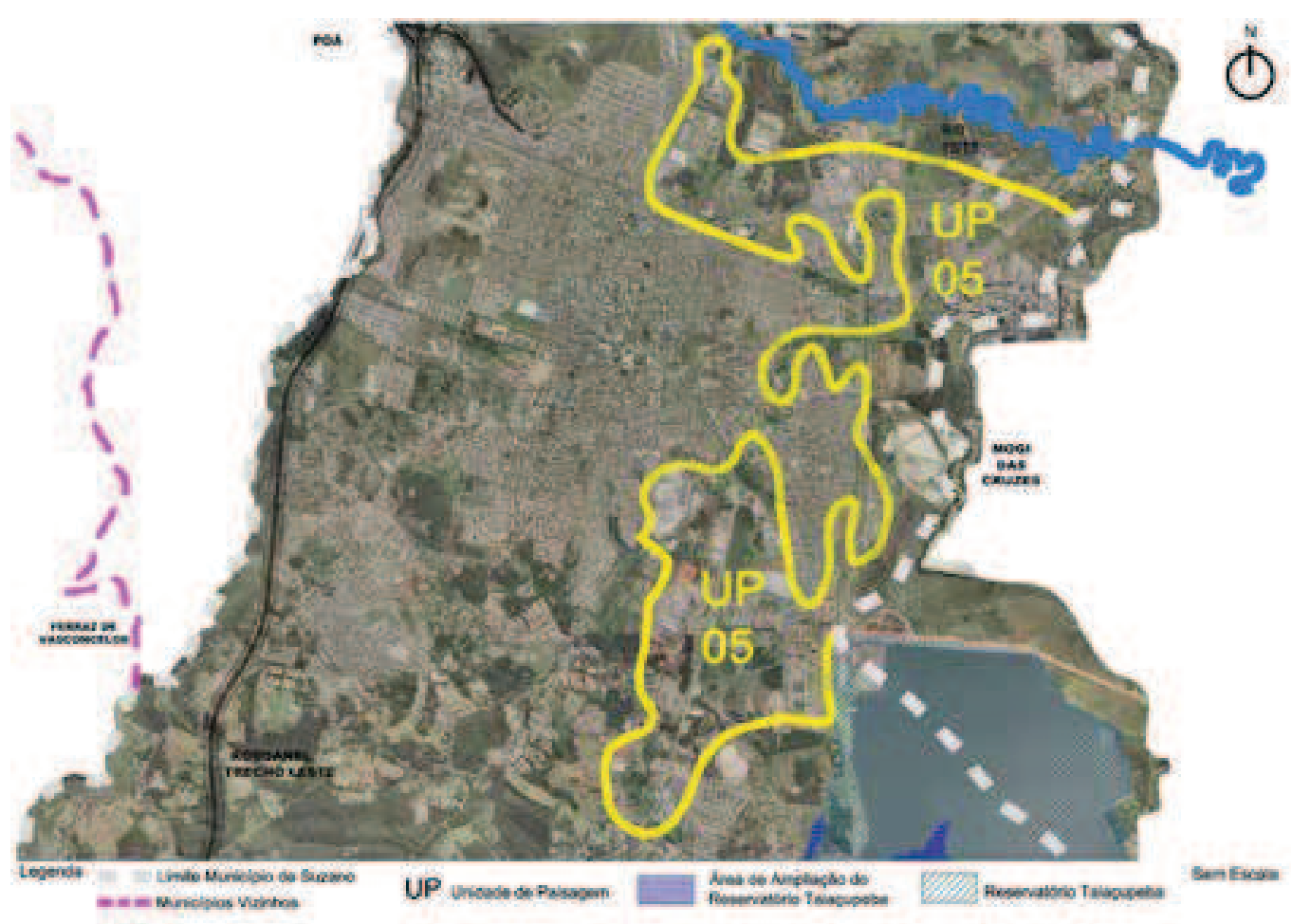

Figura 44 Suzano. Unidade de Paisagem 05.

Mapa criado por Michele de Sá Vieira e Sanderlei Fernandes Vilanova - 2012.

Fonte: Mapa aerofotogramétrico da PMS - 2008.

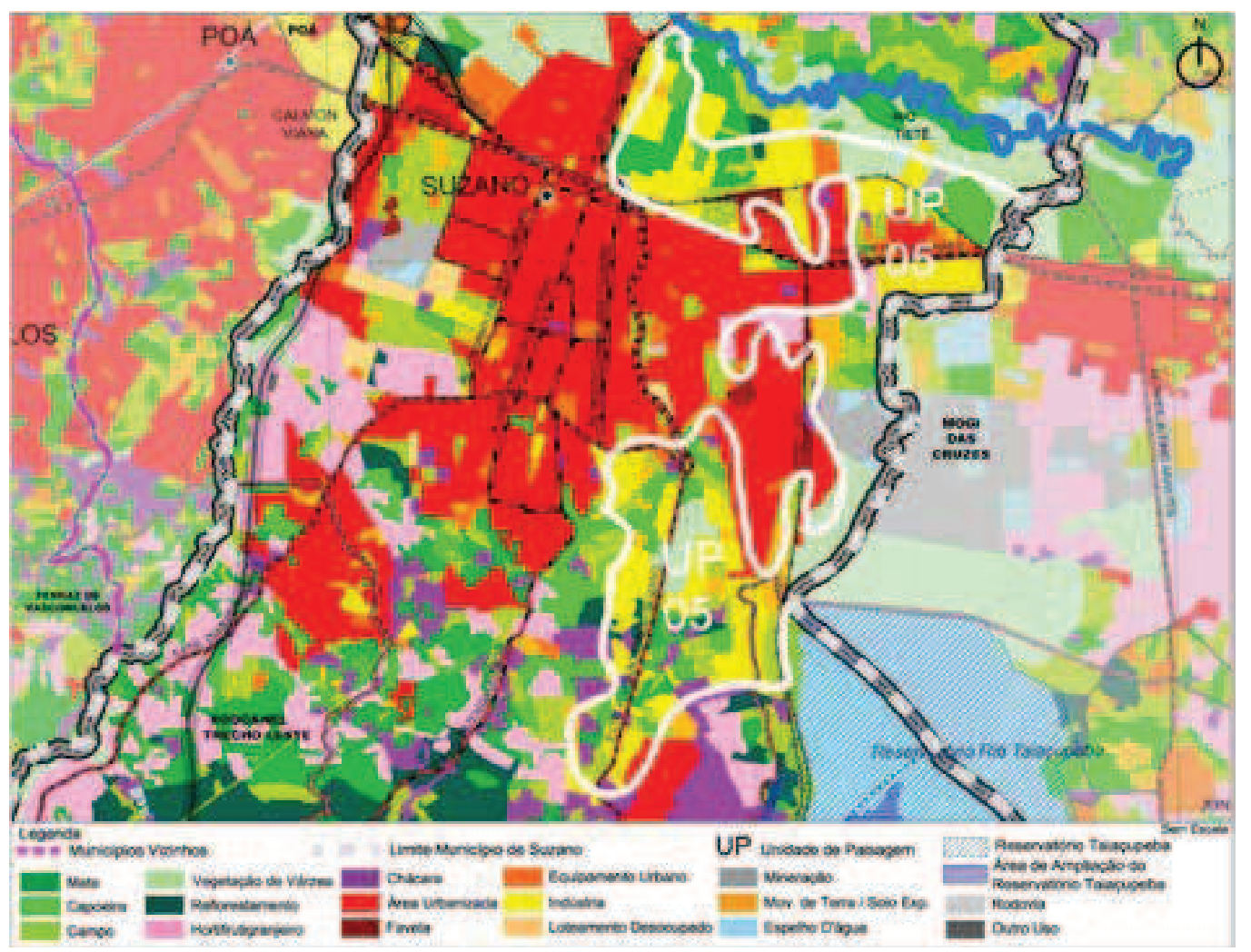

Figura 45 Suzano. Unidade de Paisagem 05.

Mapa criado por Michele de Sá Vieira e Sanderlei Fernandes Vilanova - 2012.

Fonte: Mapa do Uso e Ocupação do Solo - EMPLASA -2006. 


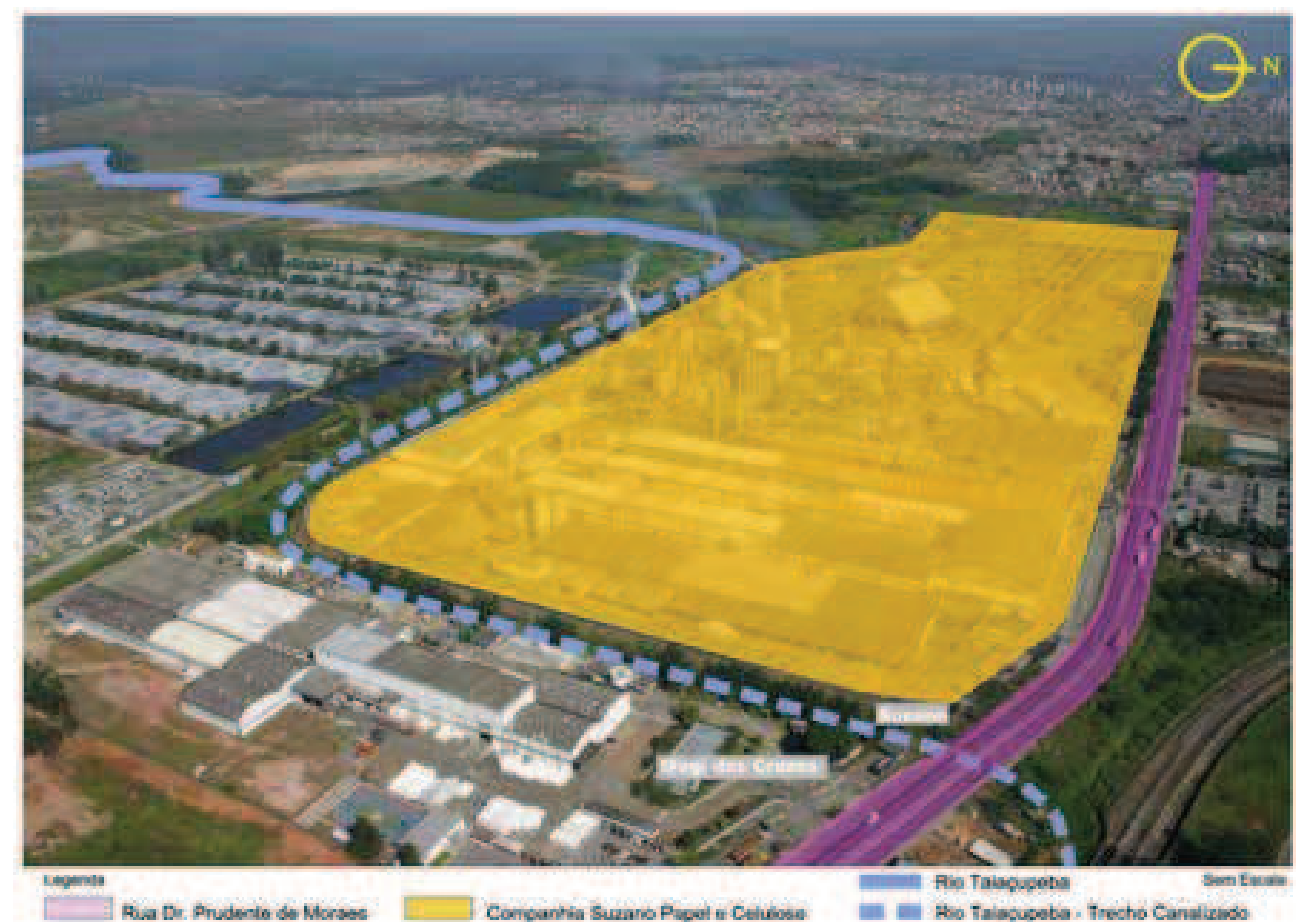

Figura 46 Suzano. Unidade de Paisagem 05. Com extenso parque industrial, a Unidade Suzano situa-se próxima ao rio Taiaçupeba, ao longo da rua Doutor Prudente de Morais (SP 66), na divisa com o município de Mogi das Cruzes.

Imagem elaborada por Michele de Sá Vieira e Sanderlei Fernandes Vilanova - 2012.

Fonte: PMS - 2008.

\section{CONFLITOS}

A instalação intensa das indústrias junto à várzea do rio Tietê é, sem dúvida, o grande conflito existente nesta unidade de paisagem, pois parte das edificações estão dentro da própria APA, enquanto outras se encontram próximas.

Os diversos pontos de movimentação de terra, com solo exposto, além da extensa cava de mineração, a qual inclusive se transpõe para o município de Mogi das Cruzes - gerando alta exploração com relação aos recursos minerais -, são outros pontos conflitantes.

\section{CENÁRIOS FUTUROS POSSÍVEIS}

A existência de capoeiras, campos e vegetação de várzea próximos à represa de Taiaçupeba, além do valor cênico do local, contribuem de maneira significativa para que este espaço possa ter seu uso destinado ao turismo, recebendo estruturas vinculadas a atividades de recreação e lazer, como os parques lineares, nos locais próximos às ocupações, e corredores ecológicos nas áreas onde as ocupações não acontecem, mas que, no entanto, oferecem a possibilidade de serem potencializadas pela vegetação. Devido ao fato de este local possuir uma beleza luxuriante, apresenta-se como um dos altos potenciais paisagísticos ambientais do território.

Como cenário futuro negativo, entende-se que, embora a várzea do Tietê seja uma das grandes potencialidades do município, o fato de abrigar indústrias, bem como a 
ampliação e inserção de novos empreendimentos, com esta consolidação, a impermeabilização junto ao rio irá aumentar, podendo provocar desastres ambientais que, hoje (2012), já acontecem, como as inundações.

A expansão e a consolidação das ocupações residenciais neste local também são graves problemas, pois provocam a ampliação da impermeabilização do solo, que contribui diretamente com o aumento das inundações, considerando-se que estes assentamentos estão situados na várzea do rio Tietê.

\section{UNIDADE DE PAISAGEM 06}

\section{CARACTERÍSTICAS}

Esta unidade de paisagem, que conterá parte do Rodoanel Leste, está instalada sobre relevo praticamente plano, caracterizando-se principalmente pelo intenso cultivo de hortifrutigranjeiros, disseminados por toda a bacia do rio Guaió, além do cultivo voltado ao reflorestamento de eucaliptos localizados ao sul desta UP. Com relação à urbanização, pode ser considerada incipiente, a exemplo das praças já instaladas.

É também um espaço de grande interesse ambiental e ecológico, em função de possuir diversos fragmentos de mata nativa, distribuídos sobre relevo um pouco mais acidentado em direção ao centro do território, e áreas de campo e capoeira, além de uma pequena quantidade de vegetação de várzea junto ao rio Guaió.

A existência de chácaras ocorre de maneira menos expressiva quando comparamos com outras partes do território, como a Unidade de Paisagem 08.

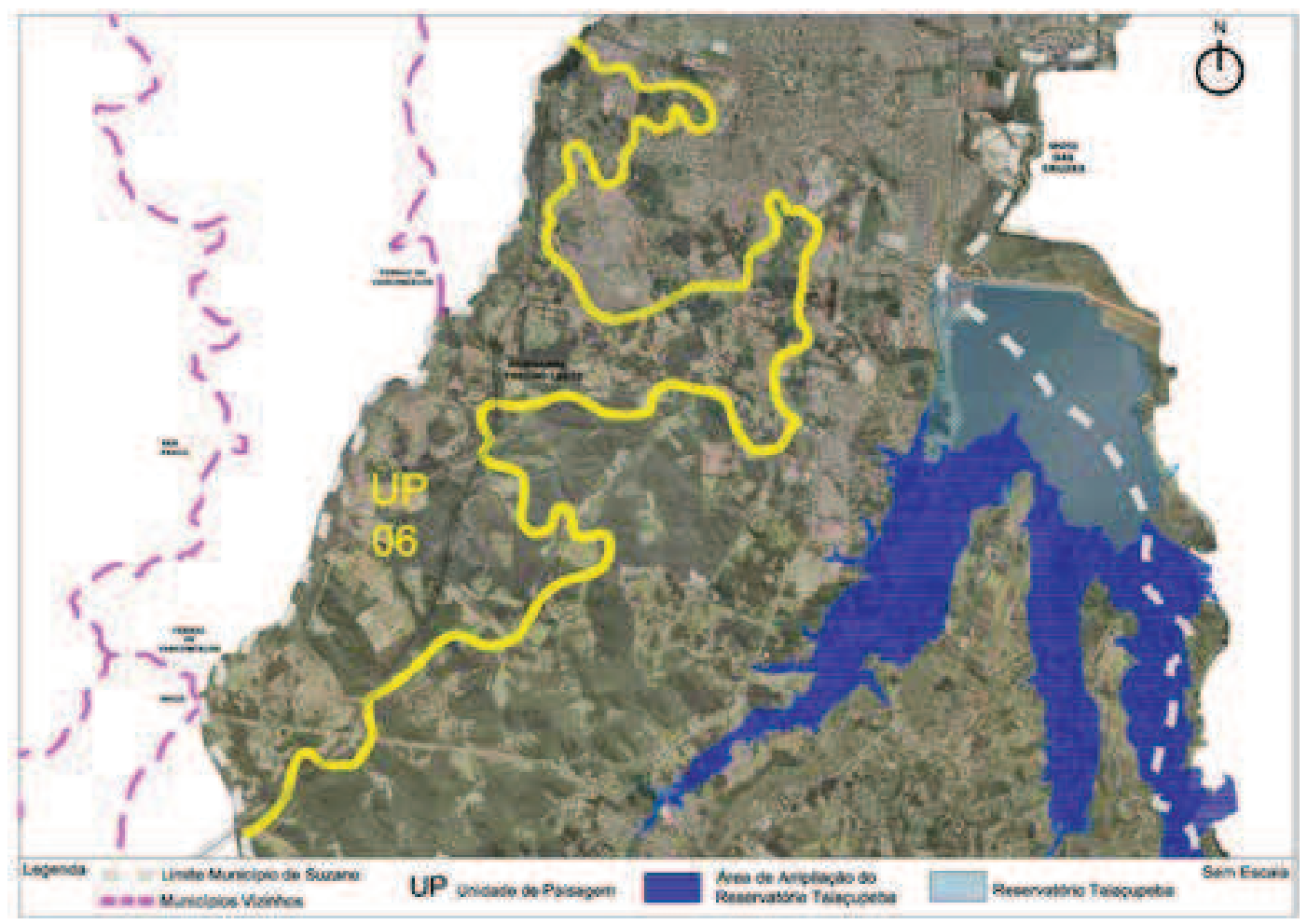

Figura 47 Suzano. Unidade de Paisagem 06.

Mapa criado por Michele de Sá Vieira e Sanderlei Fernandes Vilanova - 2012.

Fonte: Mapa aerofotogramétrico da PMS - 2008. 


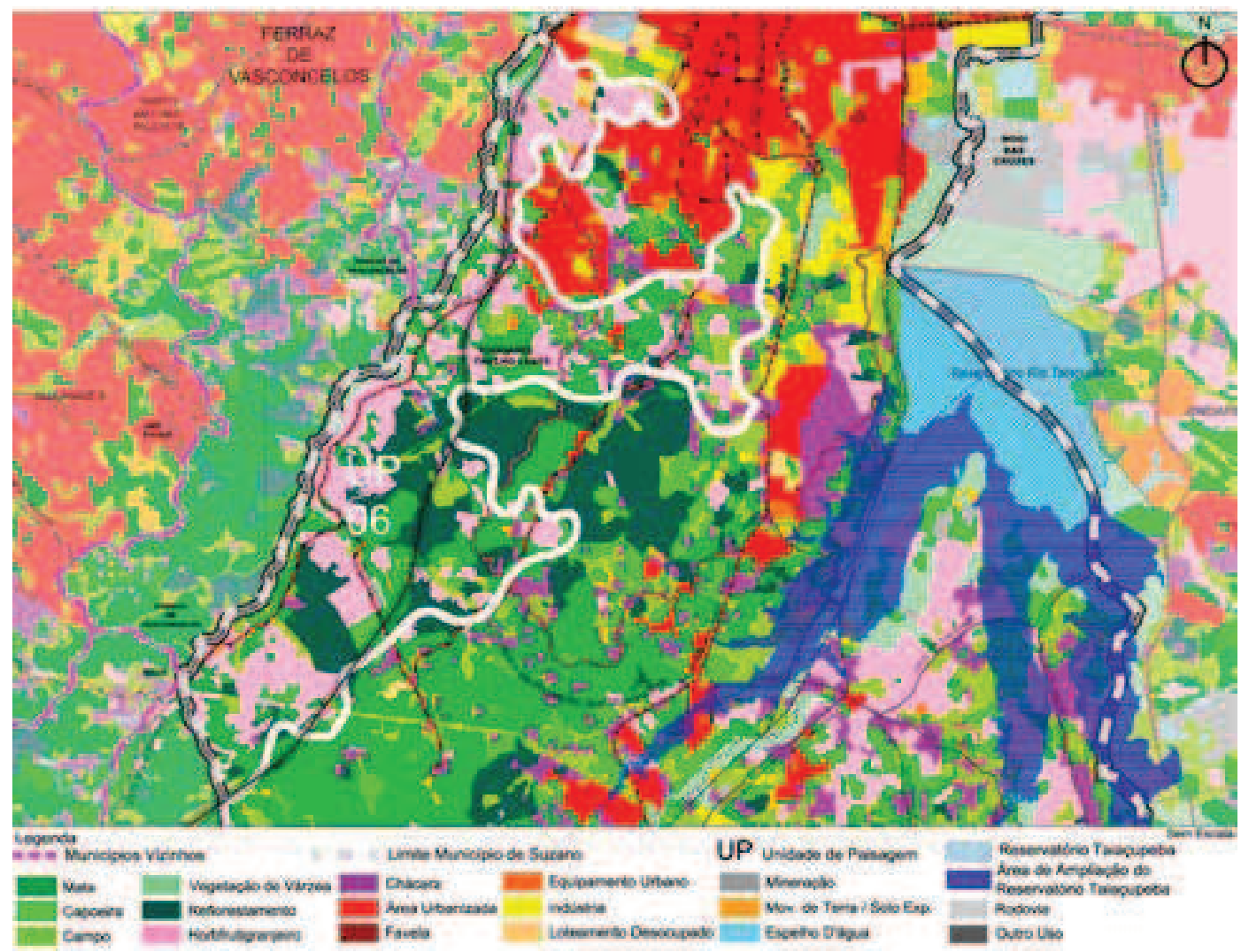

Figura 48 Suzano. Unidade de Paisagem 06.

Mapa criado por Michele de Sá Vieira e Sanderlei Fernandes Vilanova - 2012.

Fonte: Mapa do Uso e Ocupação do Solo - EMPLASA - 2006.

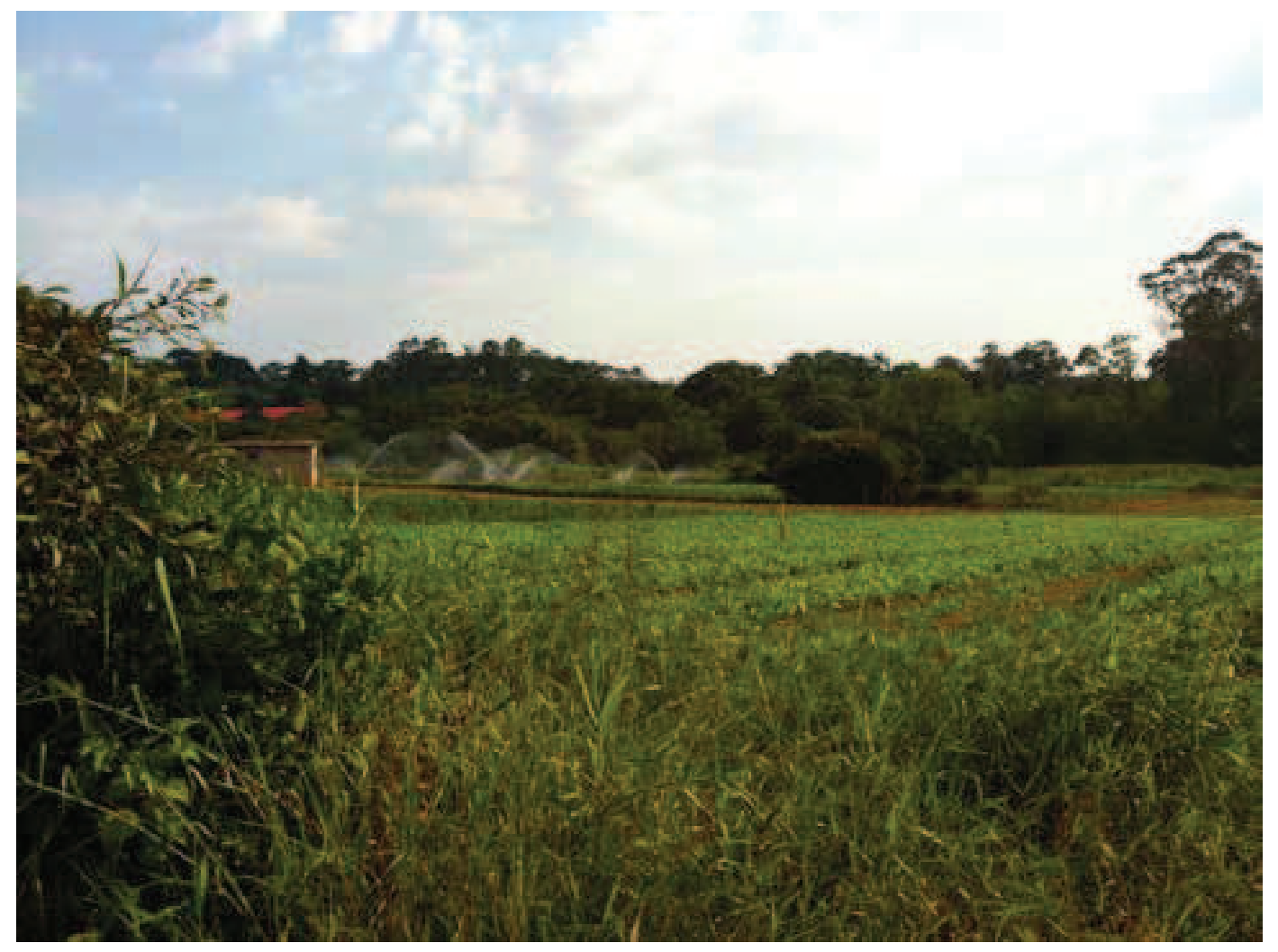

Figura 49 Suzano. Unidade de Paisagem 06. Ao longo da estrada do Viaduto, esta unidade de paisagem contém uma das maiores áreas vinculadas ao cultivo da agricultura. Sem dúvida, a atividade é proveniente do rico sistema hídrico da bacia do Guaió.

Fonte: Arquivo Sanderlei Fernandes Vilanova - 2012. 


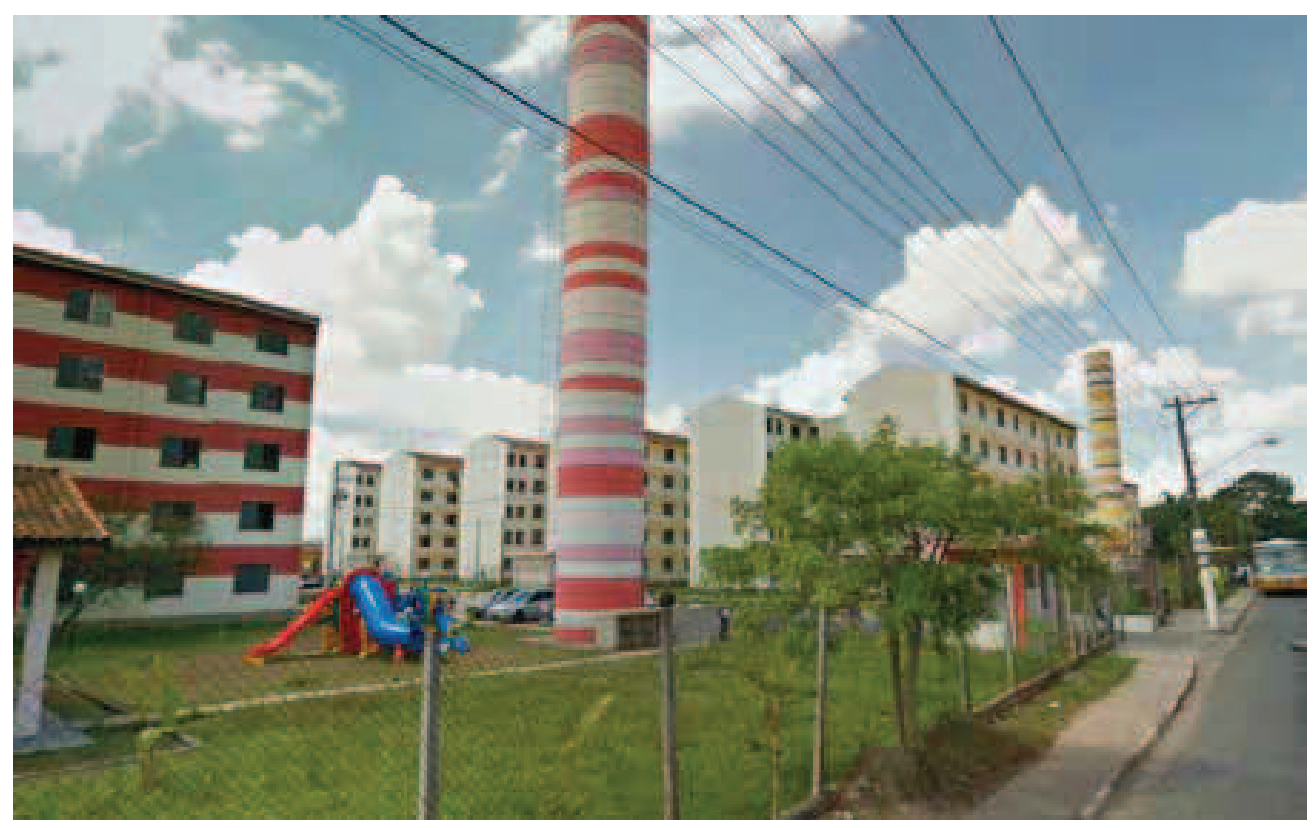

Figura 50 Suzano. Unidade de Paisagem 06. Embora o predomínio, no que se refere ao uso e ocupação do solo desta região, seja voltado para a agricultura e recobrimento de vegetação, aí se situam unidades habitacionais por exemplo, na estrada Santa Mônica.

Fonte: Google Maps - 2012.

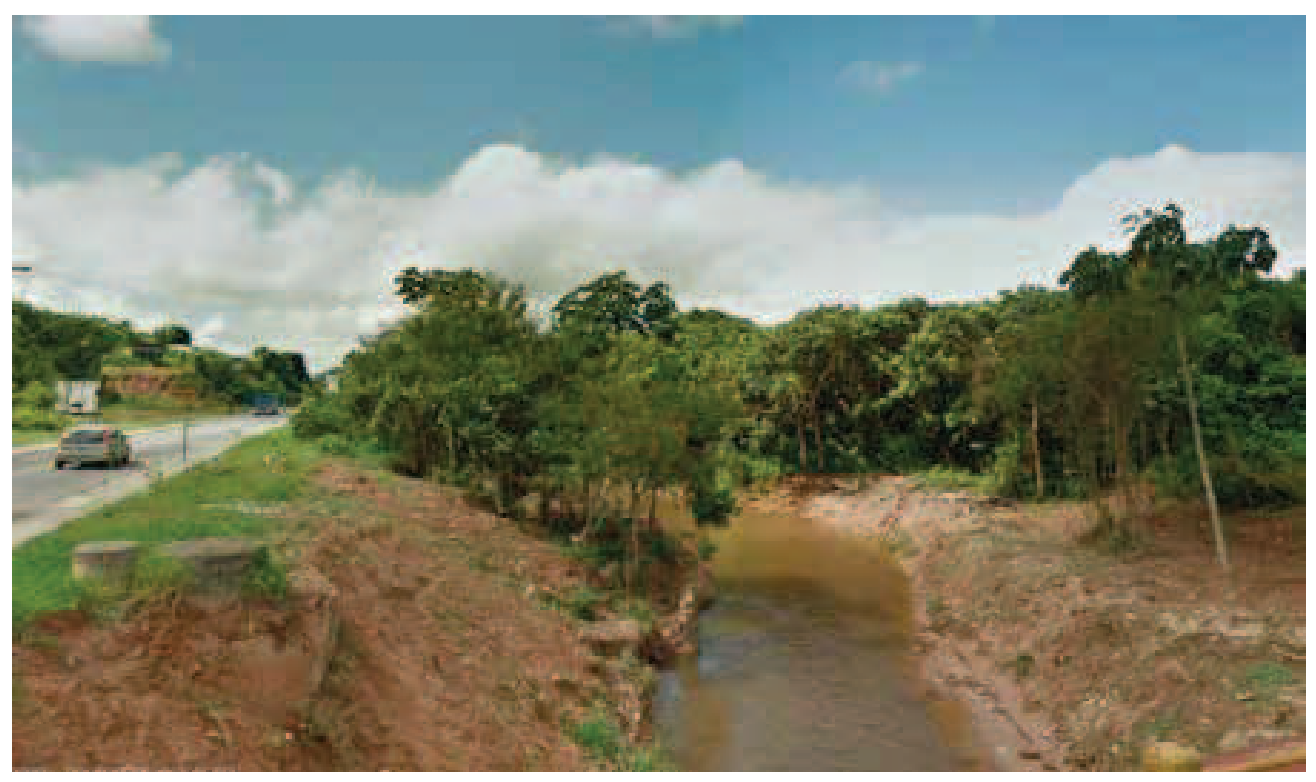

Figura 51 Suzano. Unidade de Paisagem 06. Ainda que parte da vegetação ao longo do rio Guaió esteja preservada, com fragmentos de mata ciliar, observa-se que em alguns locais o solo está completamente exposto, como aparece no trecho ao longo da estrada Santa Mônica.

Fonte: Google Maps - 2012.

\section{CONFLITOS}

Existem situações que hoje (2012) contribuem intensamente para a degradação deste ambiente, como as movimentações de terra que levam à exposição do solo, os desmatamentos pontuais, a caça ilegal de animais silvestres, além das grandes áreas de reflorestamento de eucalipto, que se impõem entre os fragmentos de mata nativa, promovendo rupturas na continuidade dos fluxos de energia destas manchas. 


\section{CENÁRIOS FUTUROS POSSÍVEIS}

A criação de corredores ecológicos através do aproveitamento dos inúmeros fragmentos de mata, capoeiras e campos existentes e a utilização do sistema hídrico expressivo na bacia do rio Guaió são potencialidades positivas.

Gerado pelo governo do Estado, o Rodoanel Leste propiciará ruptura e extinção de diversos corpos d'água, fragmentos de vegetação, áreas voltadas à agricultura, bem como intensas movimentações de terra e retirada de famílias, além de não permitir a criação de corredores ecológicos que possibilitem a conexão de florestas de mata nativa existentes no município de Suzano.

\section{UNIDADE DE PAISAGEM 07}

\section{CARACTERÍSTICAS}

Esta unidade contempla urbanização em fase de consolidação, possuindo relevo plano em alguns locais e um pouco mais acidentado em outros. Contém o maior conjunto de chácaras do município próximo à represa de Taiaçupeba, circundado por ocupações urbanas, cultivo de hortifrutigranjeiros, baixa concentração de vegetação de mata nativa, capoeiras, campos, e reflorestamento.

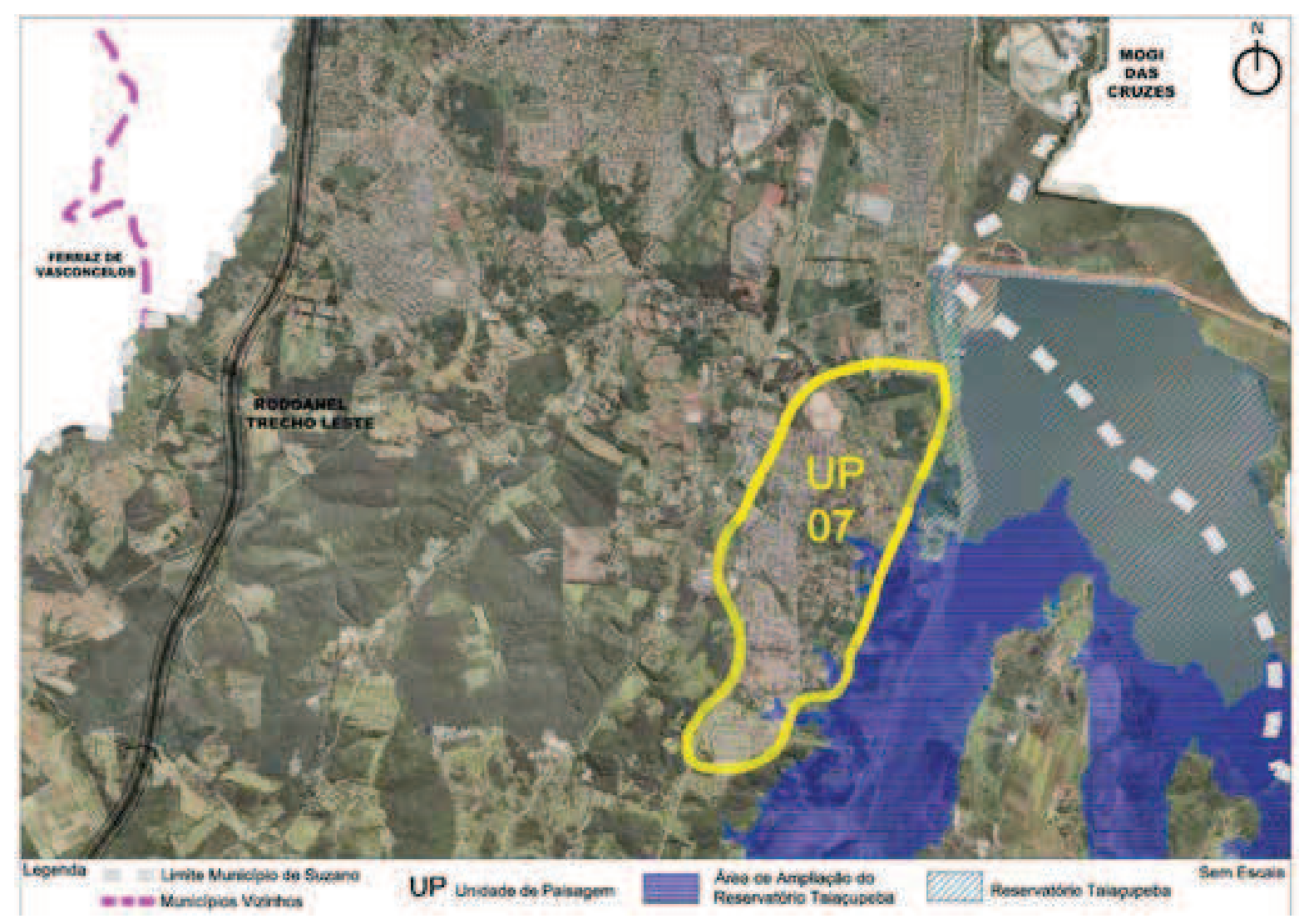

Figura 52 Suzano. Unidade de Paisagem 07.

Mapa criado por Michele de Sá Vieira e Sanderlei Fernandes Vilanova - 2012.

Fonte: Mapa aerofotogramétrico da PMS - 2008. 


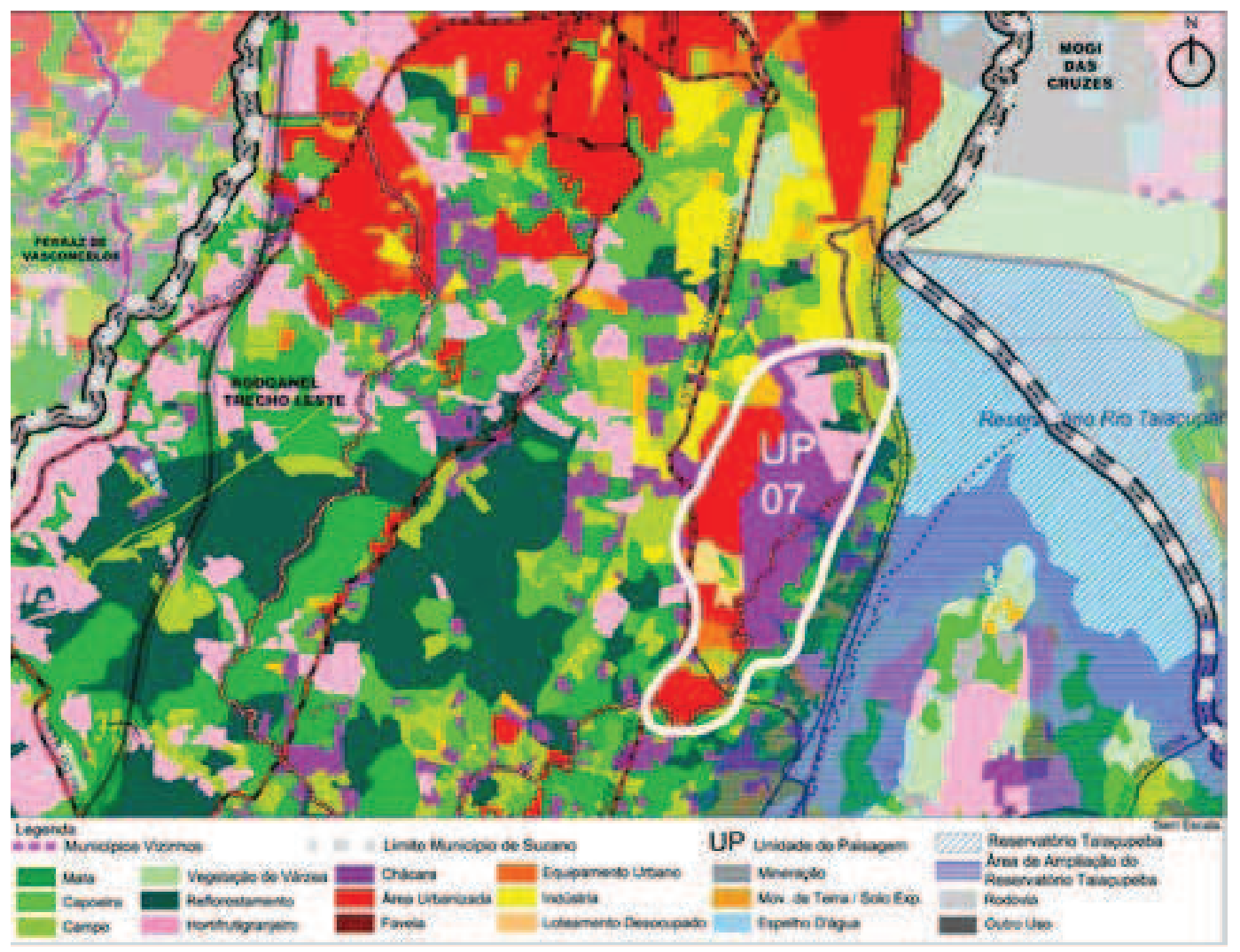

Figura 53 Suzano. Unidade de Paisagem 07.

Mapa criado por Michele de Sá Vieira e Sanderlei Fernandes Vilanova - 2012.

Fonte: Mapa do Uso e Ocupação do Solo - EMPLASA - 2006.

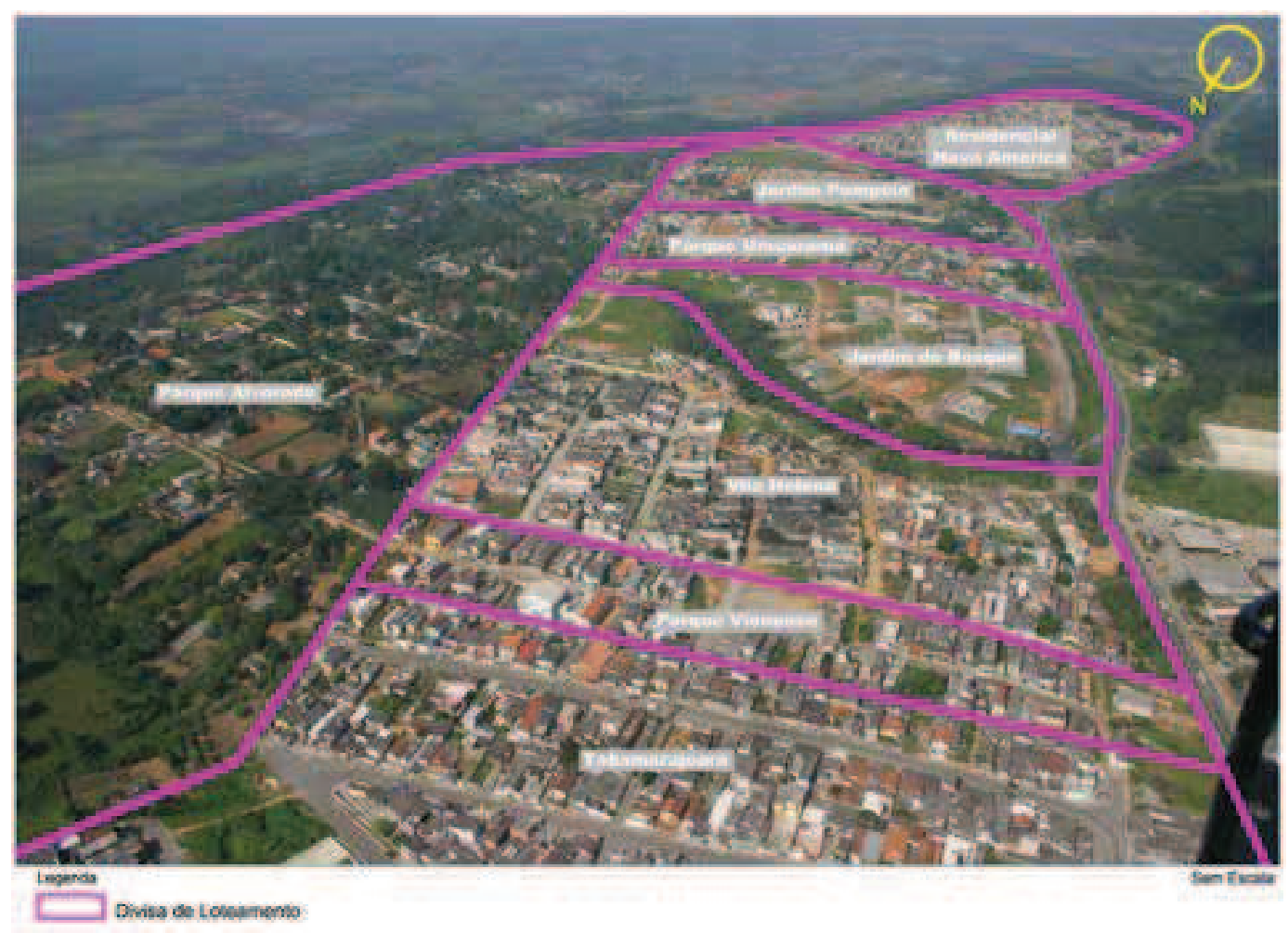

Figura 54 Suzano. Unidade de Paisagem 07. Os loteamentos Parque Vienense, Vila Helena, Jardim do Bosque, Parque Umuarama, Jardim Pompeia e Residencial Nova América estão próximos à represa de Taiaçupeba, podendo desfrutar de certa forma de futuras instalações turísticas que venham a ocorrer.

Imagem elaborada por Michele de Sá Vieira e Sanderlei Fernandes Vilanova - 2012.

Fonte: PMS - 2008. 


\section{CONFLITOS}

A ampliação da represa propiciará a eliminação de espaços destinados ao cultivo de hortifrutigranjeiros, além de diversos recursos florestais, tais como matas, campos e capoeiras, diminuindo os recursos ambientais existentes no território.

Outro conflito trata da movimentação de terra com solo exposto, que também acontece nesta unidade devido, especialmente, às novas ocupações.

\section{CENÁRIOS FUTUROS POSSÍVEIS}

Como cenário futuro positivo esta unidade contém uma das maiores oportunidades que o município oferece, pelo fato de poder abrigar estruturas turísticas e por estar próxima à represa de Taiaçupeba, tendo a possibilidade, portanto, de explorar o seu valor cênico.

Como cenário negativo, a expansão constante das manchas de ocupação podem sobrepor-se em relação à implementação de estruturas turísticas.

\section{UNIDADE DE PAISAGEM 08}

\section{CARACTERÍSTICAS}

Contém a maior área em extensão do território no que se refere aos interesses ecológicos, ambientais e paisagísticos, dado ao fato de possuir grandes fragmentos de matas nativas consolidados sobre relevo bastante colinoso e especial. Além disso, contempla importantes áreas de reflorestamento, capoeiras e campos.

As chácaras recreativas ocupam parte significativa deste espaço. Em contrapartida às áreas ocupadas pela indústria e pelo cultivo de hortifrutigranjeiros são praticamente inexpressivas em termos quantitativos. Com relação à urbanização, esta apresenta-se incipiente.

\section{CONFLITOS}

As ocupações urbanas, as indústrias, a exploração mineral, a movimentação de terra com solo exposto, a disposição irregular de resíduos por municípios vizinhos, os desmatamentos pontuais, os reflorestamentos, que se impõem entre os fragmentos de matas nativas, bem como a caça ilegal de animais silvestres, contribuem significativamente para a degradação desta unidade de paisagem.

\section{CENÁRIOS FUTUROS POSSÍVEIS}

Por esta unidade de paisagem ser a que contém a maior quantidade de fragmentos florestais naturais, consequentemente, também possui as mais amplas possibilidades com relação ao estabelecimento de corredores ecológicos, para que estes possam ligar as manchas existentes. 

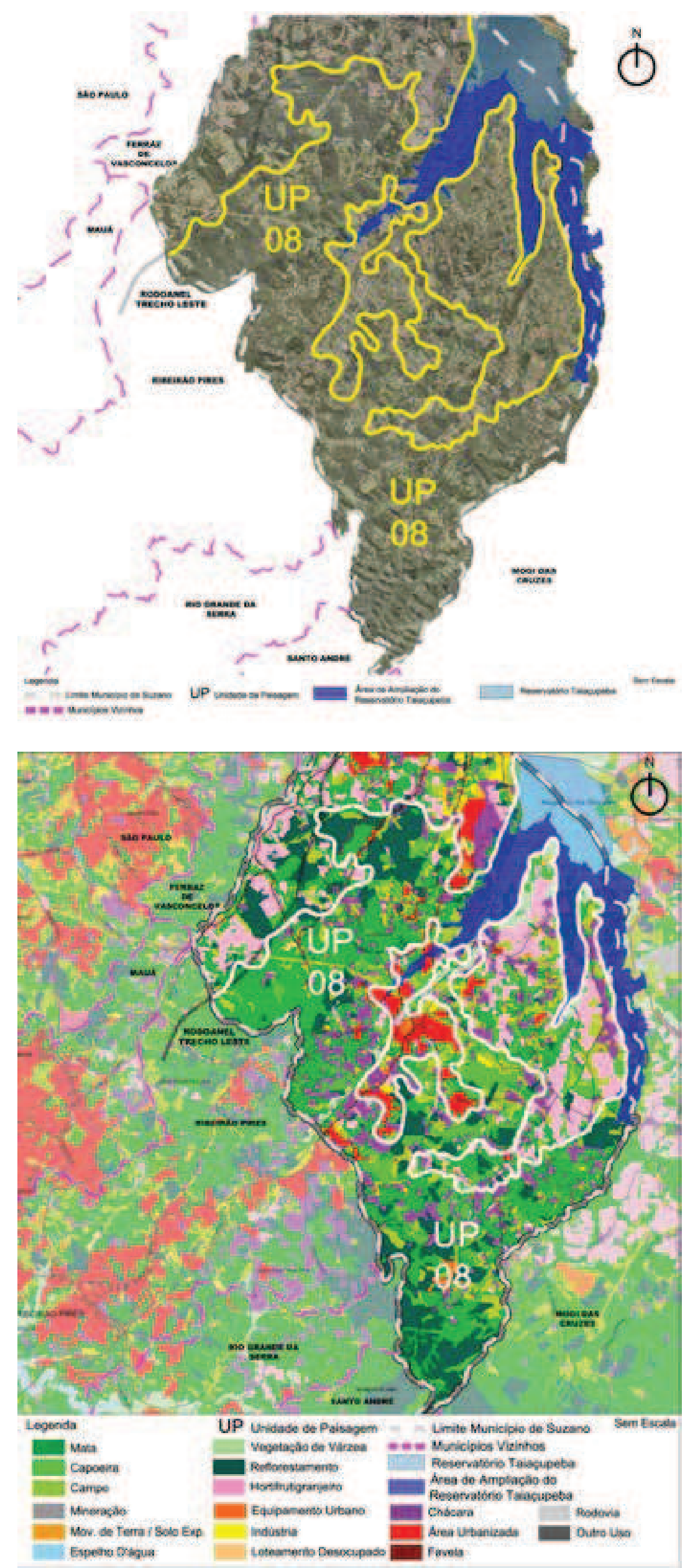

Figura 55 Suzano. Unidade de Paisagem 08.

Mapa criado por Michele de Sá Vieira e Sanderlei Fernandes Vilanova-2012.

Fonte: Mapa aerofotogramétrico da PMS - 2008
Figura 56 Suzano. Unidade de Paisagem 08. Mapa criado por Michele de Sá Vieira e Sanderlei Fernandes Vilanova - 2012. Fonte: Mapa do Uso e Ocupação do Solo EMPLASA $-2006$. 


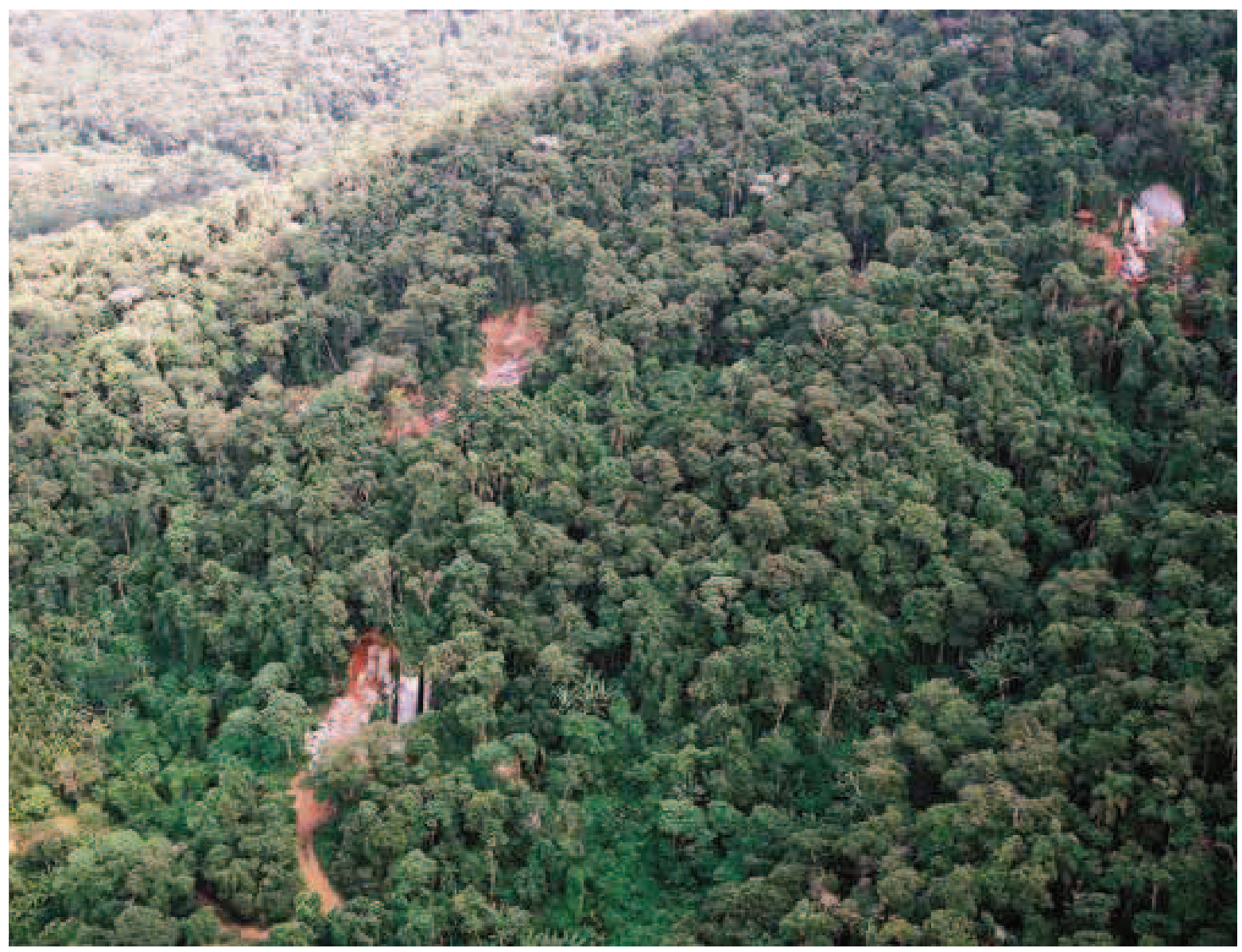

Figura 57 Suzano. Unidade de Paisagem 08. Se, por um lado, esta unidade apresenta características intensamente naturais, como a grande quantidade de fragmentos florestais e recursos hídricos, por outro, vê-se que a exploração mineral existente em alguns pontos, dentro dos fragmentos de mata, acaba por gerar a degradação das florestas, dado ao fato de esta ser exercida, em diversos momentos, de forma predatória e irregular. Fonte: PMS - 2008

Outros aspectos que podem ser observados para que estas conectividades aconteçam são os inúmeros espaços ocupados por capoeira e campos que podem ser utilizados para a passagem dos corredores.

A existência do rico sistema hídrico é outra característica que contribui para que as manchas possam ser interligadas por fragmentos florestais lineares, uma vez que a água é um importante recurso capaz de colaborar com esta ação.

Atividades vinculadas ao alto valor cênico, como as turísticas-ecológicas, bem como as de extrações vegetal e mineral regulares, também podem ser desenvolvidas nesta região.

Como cenário negativo há, constantemente, a eliminação total ou parcial de significativos corpos d'água e fragmentos florestais em função da expansão das ocupações urbanas, além das pressões advindas de fatores vinculados à agricultura e à exploração mineral.

Além disso, o interesse imobiliário tende a incentivar atividades vinculadas à exploração dos recursos naturais, como as paisagens que aí estão, tornando-se também um forte atrativo para que a região seja ocupada de maneira irregular por chácaras de recreio, dentre outras. 


\section{UNIDADE DE PAISAGEM 09}

\section{CARACTERÍSTICAS}

Embora esta região seja de grande interesse ecológico, ambiental e paisagístico, o que predomina são as ocupações urbanas em fase de consolidação, dispostas em sete blocos, todas situadas em relevo acidentado. $\bigcirc$ uso e a ocupação do solo deste espaço também são caracterizados pela presença de praças pouco urbanizadas, indústrias, chácaras, cultivo de hortifrutigranjeiro, fragmentos de mata nativa, campos e capoeiras.

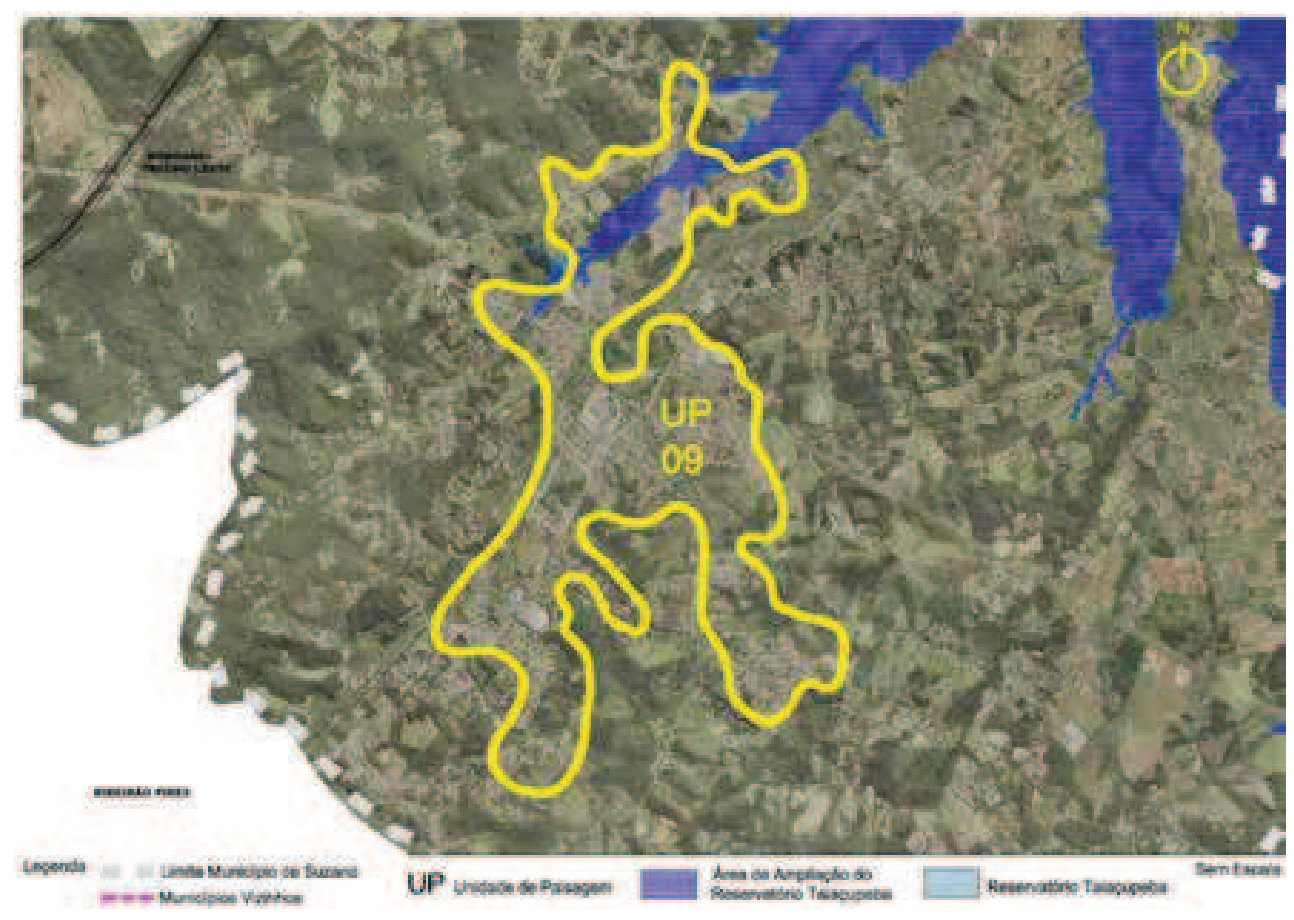

Figura 58

Suzano. Unidade de Paisagem 09. Mapa criado por Michele de Sá Vieira e Sanderlei Fernandes Vilanova-2012. Fonte: Mapa aerofotogramétrico da PMS - 2008.

Figura 59

Suzano.

Unidade de Paisagem 09. Mapa criado por Michele de Sá Vieira e Sanderlei Fernandes Vilanova 2012.

Fonte: Mapa do Uso e Ocupação do Solo - EMPLASA -2006 . 


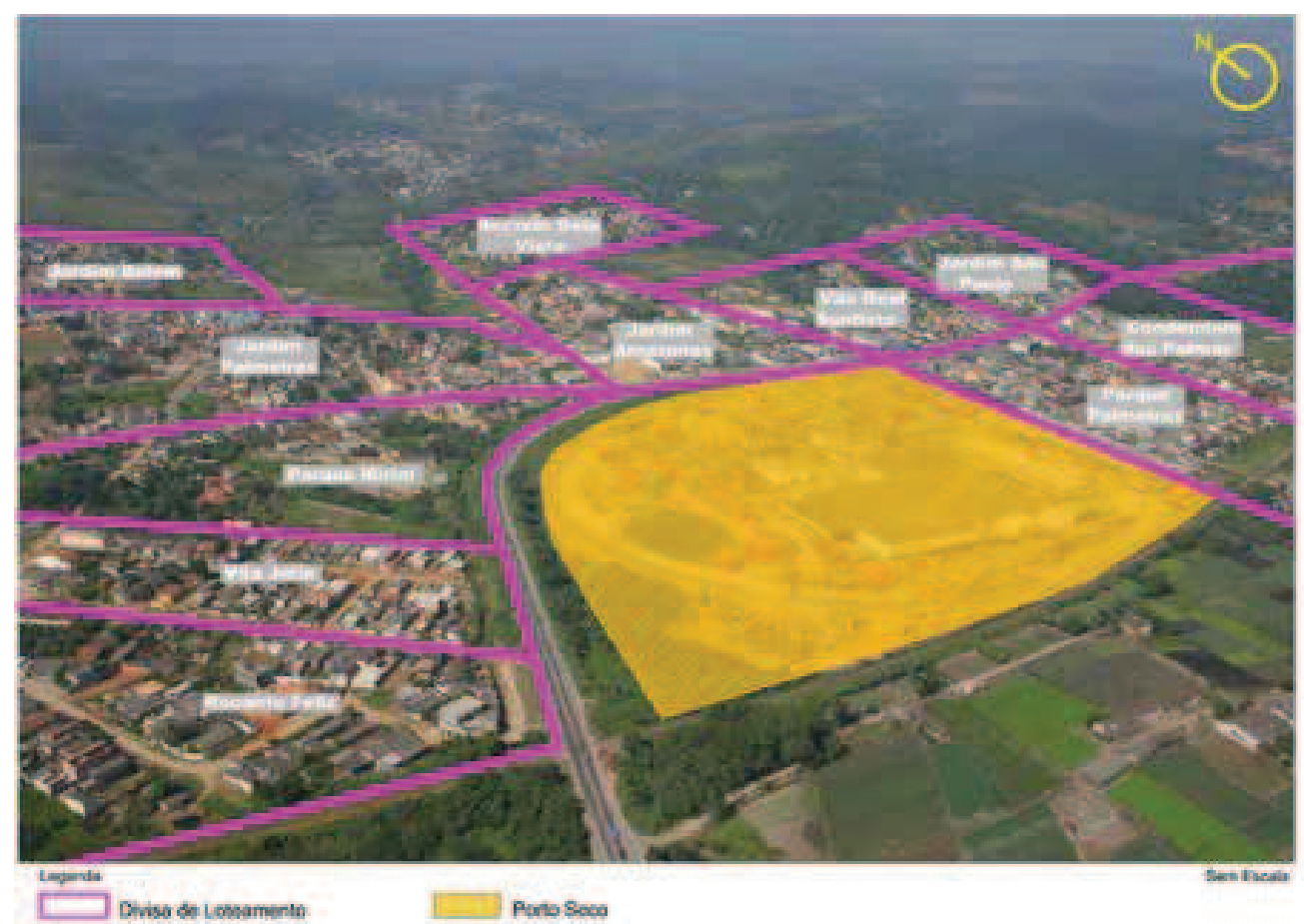

Figura 60 Suzano. Unidade de Paisagem 09. Ainda que, dentre as Unidades de Paisagem existentes junto à Área de Proteção dos Mananciais (APM), esta seja a que contém a vegetação nativa mais degradada, em decorrência das ocupações urbanas por loteamentos (Jardim Amazonas, Vila Real Santista, Parque Palmeiras, Recanto Feliz, Condomínio das Palmas), também possui valor cênico, sendo o seu entorno imediato cercado por fragmentos florestais.

Imagem elaborada por Michele de Sá Vieira e Sanderlei Fernandes Vilanova - 2012.

Fonte: PMS - 2008.

\section{CONFLITOS}

As ocupações urbanas existentes nesta unidade são os elementos principais geradores de conflitos na Área de Proteção dos Mananciais (APM), em função da degradação ambiental promovida por elas. Além disso, também se constituem como uma barreira para que ocorra uma possível conexão entre os fragmentos de mata nativa existentes na Unidade de Paisagem 08.

No que se refere à vegetação, os desmatamentos pontuais, assim como a caça de animais silvestres e a presença de indústrias neste espaço que possui tantos fragmentos, ampliam a degradação da região.

\section{CENÁRIOS FUTUROS POSSÍVEIS}

Por outro lado, a existência de fragmentos de mata nativa, capoeira e campo, permitem o desenvolvimento de interligações com as demais manchas de mata nativa existentes no entorno.

Os fragmentos de mata, capoeira e campo, bem como a presença das ocupações, indicam a possibilidade de implantação de parques lineares junto à ampliação da represa de Taiaçupeba, possibilitando que a população local tenha áreas de recreação aquática. 
Apesar da enorme potencialidade paisagística existente na região sul do território, o que se verifica é que os fortes núcleos de ocupações urbanas presentes, a exemplo dos que existem na Unidade de Paisagem 09, tendem a expandir e consolidar, tendo, como consequência, a extinção e contaminação de significativos fragmentos florestais e corpos d'água.

\section{UNIDADE DE PAISAGEM 10}

\section{CARACTERÍSTICAS}

Com assentada urbanização incipiente instalada sobre relevo parcialmente plano e colinoso, esta Unidade possui como principal característica o forte caráter paisagístico, por ser lindeira à represa de Taiaçupeba. Na área existem extensas regiões de chácaras vinculadas ao cultivo de hortifrutigranjeiros.

No que se refere à vegetação, suas diversas áreas de campo, capoeiras, fragmentos de mata nativa e vegetação de várzea dão a esta unidade grande caráter ecológico e ambiental.

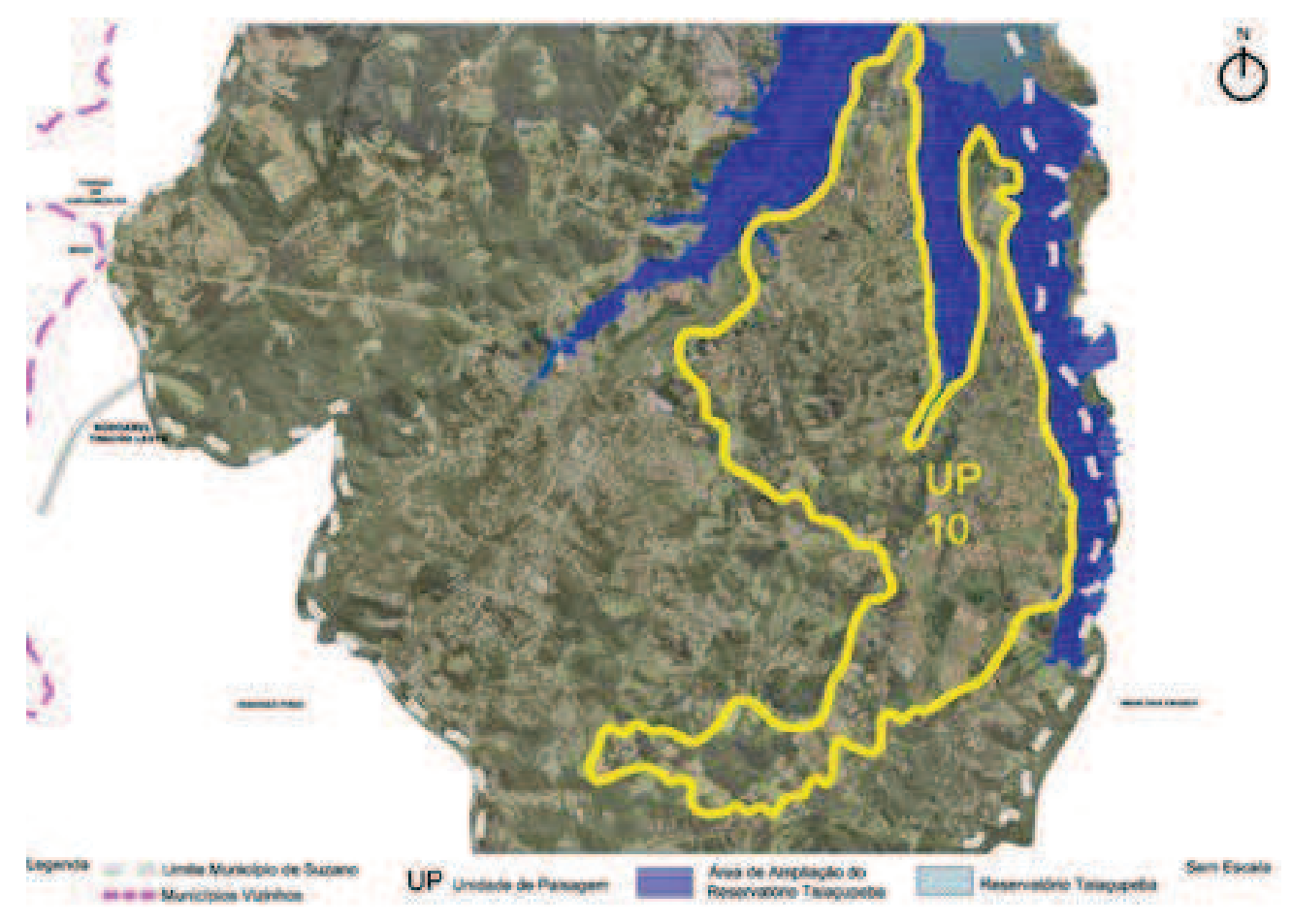

Figura 61 Suzano. Unidade de Paisagem 10.

Mapa criado por Michele de Sá Vieira e Sanderlei Fernandes Vilanova - 2012.

Fonte: Mapa aerofotogramétrico da PMS - 2008.

\section{CONFLITOS}

Com relação aos conflitos, eles ocorrem em função da presença das ocupações urbanas desprovidas de infraestrutura vinculada ao saneamento, bem como da forma intensa que a agricultura usufrui dos recursos hídricos. 
No que se refere à vegetação, registram-se alguns fatos que contribuem para a sua extinção nesta unidade de paisagem como:

- a expansão da represa de Taiaçupeba, que propiciará a supressão de diversos tipos de vegetação;

- a intensa presença da agricultura, que funciona como uma barreira entre os fragmentos de mata existentes, deixando-os isolados;

- os desmatamentos pontuais, assim como a caça ilegal de animais silvestres, que também contribuem para a extinção dos fragmentos nesta região.

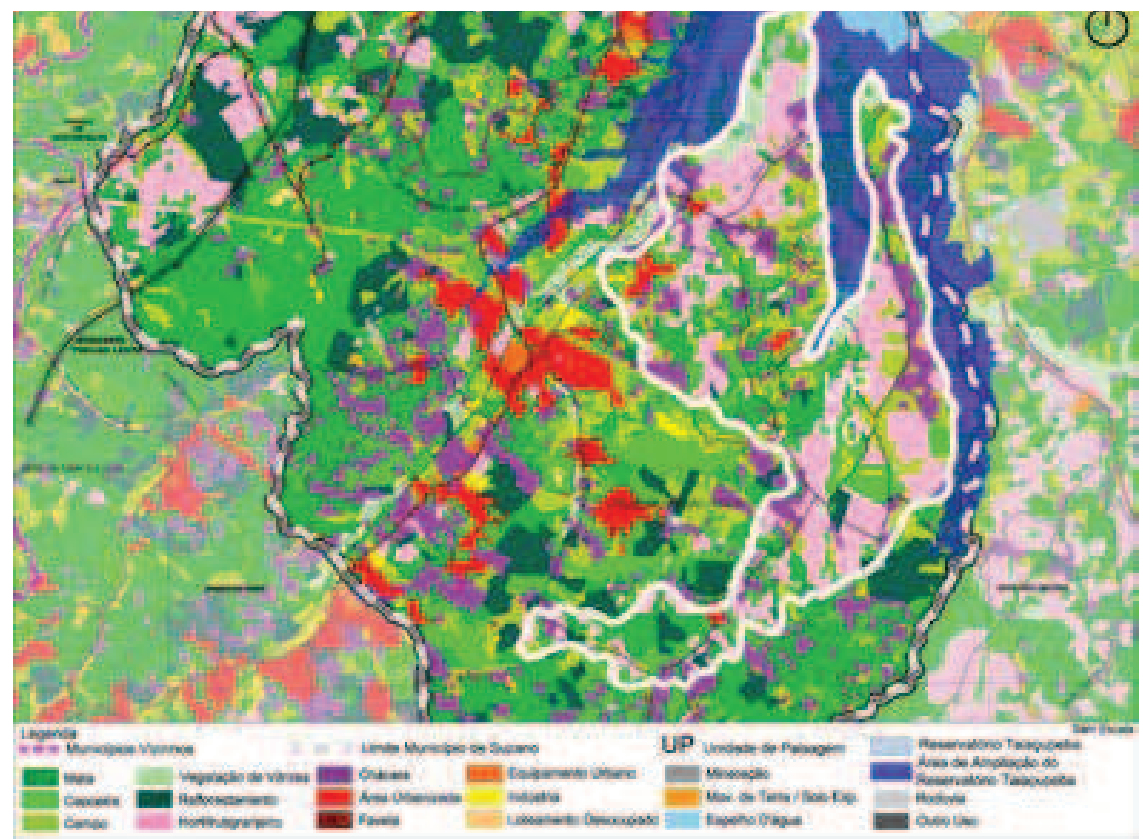

Figura 62 Suzano. Unidade de Paisagem 10.

Mapa criado por Michele de Sá Vieira e Sanderlei Fernandes Vilanova - 2012.

Fonte: Mapa do Uso e Ocupação do Solo - EMPLASA - 2006.

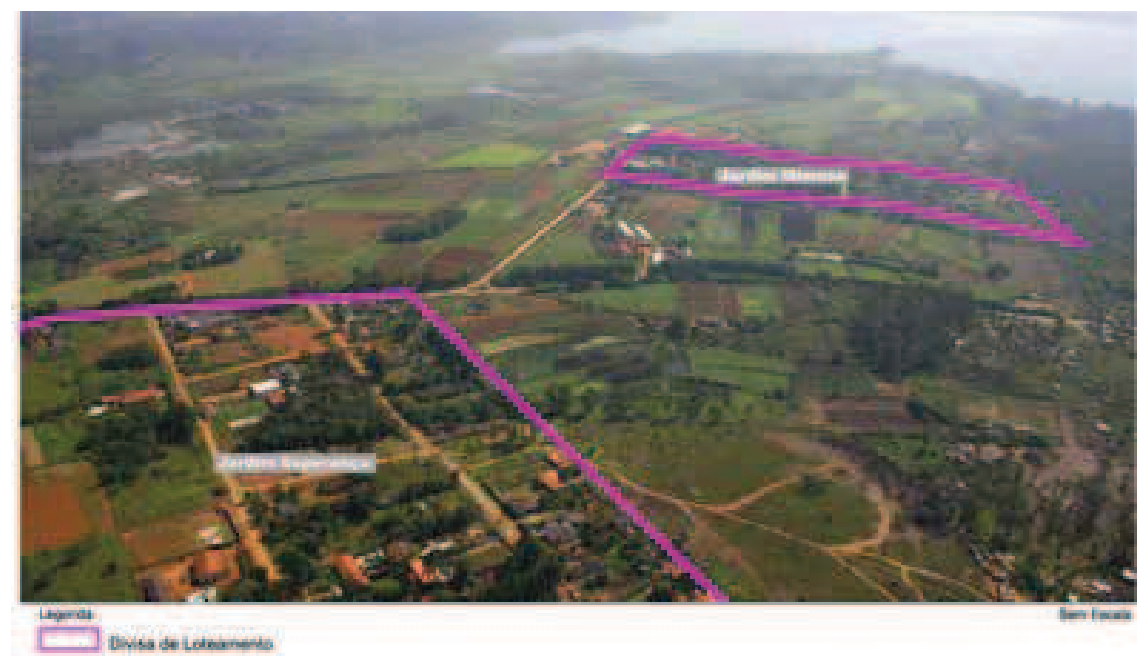

Figura 63 Suzano. Unidade de Paisagem 10. Em decorrência da proximidade da urbanização, com relação à represa de Taiaçupeba, parques lineares podem ser implantados, considerando-se que a população que vive em loteamentos como o Jardim Esperança e o Jardim Mimosa, por estarem próximos, poderão fazer uso dos equipamentos.

Imagem elaborada por Michele de Sá Vieira e Sanderlei Fernandes Vilanova - 2012.

Fonte: PMS - 2008. 


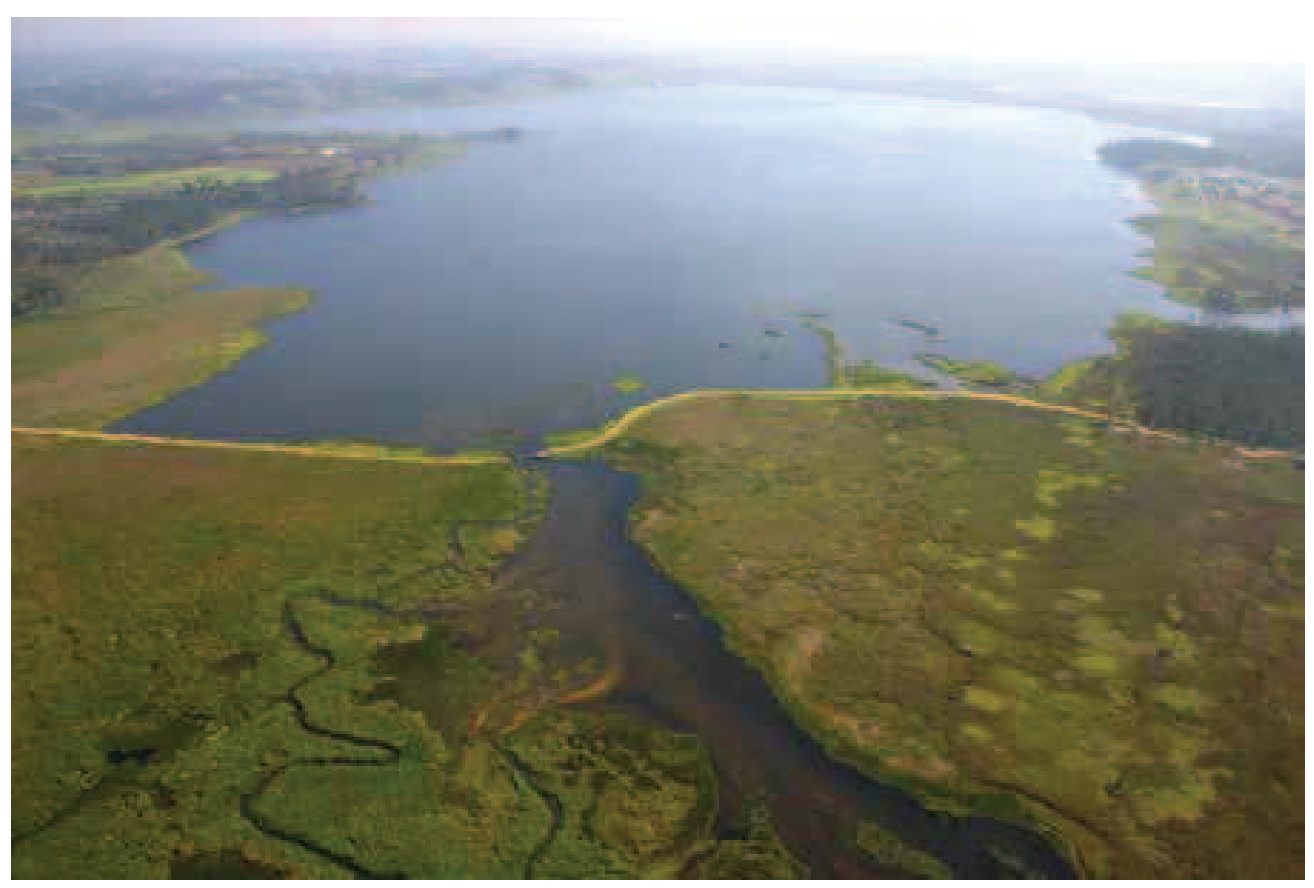

Figura 64 Suzano. Unidade de Paisagem 10. Em locais onde a população não se faz presente, uma das opções para promover a recuperação das áreas degradadas é através da implementação de corredores ecológicos ao longo da represa de Taiaçupeba.

Fonte: PMS - 2008.

\section{CENÁRIOS FUTUROS POSSÍVEIS}

As atividades futuras nesta Unidade estão vinculadas ao turismo e, portanto, à valorização da paisagem, uma vez que possui alto valor cênico por estar próxima à represa de Taiaçupeba. Os espaços junto a ela permitem a incorporação de atividades voltadas ao lazer e à recreação, como a pesca.

Outro aspecto a ser desenvolvido relaciona-se a valores voltados à recuperação ecossistêmica, pois como esta unidade contém vegetação de várzea, fragmentos de mata nativa, áreas de campo e capoeiras, corredores podem ser propostos a fim de promover conexões que restabeleçam os ecossistemas antes existentes.

Por outro lado, existe a tendência à extinção e contaminação de significativos corpos d'água e fragmentos florestais em função da expansão e consolidação das ocupações urbanas irregulares pontuais - que tendem a se ampliar -, da intensa atividade vinculada à agricultura, bem como pela existência de inúmeras chácaras.

\section{SÍNTESE DAS UNIDADES DE PAISAGENS}

Após a análise das dez unidades de paisagem, segue quadro e texto-síntese que apontam o resumo das características físicas, dos conflitos, dos cenários futuros possíveis, a relação de alguns dos inúmeros projetos, planos e ações públicas executados entre os anos de 2005 e 2011, bem como a análise comparativa entre as unidades de paisagem. 


\section{TABELA SÍNTESE}

\begin{tabular}{|c|c|c|c|c|c|}
\hline $\begin{array}{c}\text { Unidades } \\
\text { de } \\
\text { Paisagem }\end{array}$ & $\begin{array}{c}\text { Características } \\
\text { físicas }\end{array}$ & Conflitos & $\begin{array}{c}\text { Cenários futuros } \\
\text { possíveis }\end{array}$ & $\begin{array}{c}\text { Cenários futuros } \\
\text { possíveis }\end{array}$ & $\begin{array}{c}\text { Principais } \\
\text { projetos, planos } \\
\text { e ações públicas } \\
\text { já executados }\end{array}$ \\
\hline UP 01 & $\begin{array}{l}\text { - relevo plano e } \\
\text { inclinado; } \\
\text { - urbanização } \\
\text { consolidada; } \\
\text { - loteamentos } \\
\text { altamente ocupa- } \\
\text { dos; } \\
\text { - baixa con- } \\
\text { centração de } \\
\text { indústrias; } \\
\text { - baixa quanti- } \\
\text { dade de plan- } \\
\text { tações de horti- } \\
\text { frutigranjeiros; } \\
\text { - pequena presen- } \\
\text { ça de chácaras; } \\
\text { • poucos frag- } \\
\text { mentos de mata } \\
\text { nativa; } \\
\text { - baixa existência } \\
\text { de capoeiras e } \\
\text { campos; } \\
\text { - parque e praças } \\
\text { não urbanizados; } \\
\text { - ocupações } \\
\text { próximas à várzea } \\
\text { do Tietê. }\end{array}$ & $\begin{array}{l}\text { - intenso aden- } \\
\text { samento popula- } \\
\text { cional; } \\
\text { - ocupações com } \\
\text { baixa qualidade } \\
\text { estética; } \\
\text { - polvição sani- } \\
\text { tária; } \\
\text { - ocupações ir- } \\
\text { regulares em área } \\
\text { de várzea; } \\
\text { - escassez de } \\
\text { espaços livres } \\
\text { tratados; } \\
\text { - ausência de } \\
\text { convivência da } \\
\text { população com a } \\
\text { várzea do Tietê; } \\
\text { - movimentação } \\
\text { de terra com solo } \\
\text { exposto; } \\
\text { - queimadas no } \\
\text { parque Mirante do } \\
\text { Tietê. }\end{array}$ & $\begin{array}{l}\text { - convivência da } \\
\text { população com } \\
\text { o futuro parque } \\
\text { Várzeas do Tietê; } \\
\text { - canteiros cen- } \\
\text { trais capazes de } \\
\text { abrigar arbori- } \\
\text { zação urbana e } \\
\text { ciclovias; } \\
\text { - sistema hídrico } \\
\text { capaz de abrigar } \\
\text { parques lineares; } \\
\text { - praças que po- } \\
\text { dem ser tratadas } \\
\text { visando a atender } \\
\text { demandas da } \\
\text { população; } \\
\text { - Parque Mirante } \\
\text { do Tietê contém } \\
\text { grande potencial } \\
\text { para transformar- } \\
\text { se em local de } \\
\text { lazer, recreação e } \\
\text { recuperação ambi- } \\
\text { ental; } \\
\text { - universalização } \\
\text { dos serviços de } \\
\text { água e esgoto } \\
\text { pela Sabesp até } \\
\text { 2018. }\end{array}$ & $\begin{array}{l}\text { - o acumulo } \\
\text { de resíduos da } \\
\text { construção civil } \\
\text { tende a ampliar-se } \\
\text { no parque Mirante } \\
\text { do Tietê; } \\
\text { - expansão e } \\
\text { consolidação } \\
\text { das ocupações } \\
\text { residenciais ir- } \\
\text { regulares. }\end{array}$ & $\begin{array}{l}\text { - obras de } \\
\text { infraestrutura } \\
\text { urbana: pavimen- } \\
\text { tação, redes de } \\
\text { abastecimento } \\
\text { de água e coleta } \\
\text { de esgoto, além } \\
\text { de atendimento } \\
\text { de iluminação } \\
\text { pública; } \\
\text { - implantação } \\
\text { do Parque Linear } \\
\text { Ecológico Jaguari; } \\
\text { - implantação do } \\
\text { Corredor Ecológi- } \\
\text { co Recreativo no } \\
\text { loteamento Jardim } \\
\text { Revista; } \\
\text { - construção de } \\
\text { equipamentos } \\
\text { públicos, tais } \\
\text { como: creches, } \\
\text { escolas, centro } \\
\text { cultural, unidades } \\
\text { básicas de saúde } \\
\text { (UBSs); } \\
\text { - projetos de } \\
\text { urbanização de } \\
\text { áreas degradadas } \\
\text { nos loteamentos } \\
\text { Cidade Miguel } \\
\text { Badra, Jaguari e } \\
\text { Planalto; } \\
\text { - projetos de } \\
\text { ciclovias para as } \\
\text { avenidas Miguel } \\
\text { Badra e Edmil- } \\
\text { son Rodrigues } \\
\text { Marcelino; } \\
\text { - desenvolvimento } \\
\text { do Plano Munici- } \\
\text { pal de Saneamen- } \\
\text { to Ambiental. }\end{array}$ \\
\hline
\end{tabular}




\begin{tabular}{|c|c|c|c|c|c|}
\hline UP 02 & $\begin{array}{l}\text { - relevo em geral } \\
\text { acidentado e, } \\
\text { em alguns locais, } \\
\text { plano; } \\
\text { - reflorestamentos, } \\
\text { campos, capoeiras } \\
\text { e matas; } \\
\text { - plantações de } \\
\text { hortifrutigranjeiros; } \\
\text { - áreas de chá- } \\
\text { cara; } \\
\text { - urbanização } \\
\text { incipiente; } \\
\text { - praças não } \\
\text { urbanizadas; } \\
\text { - ausência de } \\
\text { parques; } \\
\text { - faz fronteira com } \\
\text { a APA da várzea } \\
\text { do rio Tietê; } \\
\text { - contém parte da } \\
\text { serra do ltapety. }\end{array}$ & $\begin{array}{l}\text { • movimentação } \\
\text { de terra com solo } \\
\text { exposto; } \\
\text { • exploração do } \\
\text { sistema hídrico } \\
\text { em função da } \\
\text { agricultura; } \\
\text { - baixa qualidade } \\
\text { com relação aos } \\
\text { aspectos urbanís- } \\
\text { ticos. }\end{array}$ & $\begin{array}{l}\text { - estabelecer } \\
\text { conexões através } \\
\text { de corredores } \\
\text { ecológicos com } \\
\text { os fragmentos de } \\
\text { mata nativa da } \\
\text { serra do ltapety; } \\
\text { - estabelecer } \\
\text { conexões através } \\
\text { de corredores } \\
\text { ecológicos com } \\
\text { os fragmentos de } \\
\text { mata nativa exis- } \\
\text { tentes na várzea } \\
\text { do rio Tietê; } \\
\text { - universalização } \\
\text { dos serviços de } \\
\text { água e esgoto } \\
\text { pela Sabesp até } \\
2018 .\end{array}$ & $\begin{array}{l}\text { - expansão e } \\
\text { consolidação } \\
\text { das ocupações } \\
\text { residenciais ir- } \\
\text { regulares. }\end{array}$ & $\begin{array}{l}\text { - obra de infraes- } \\
\text { trutura urbana: } \\
\text { pavimentação; } \\
\text { - construção de } \\
\text { equipamentos } \\
\text { públicos, tais } \\
\text { como: creches, } \\
\text { escolas e UBSs; } \\
\text { - desenvolvimento } \\
\text { do Plano Munici- } \\
\text { pal de Saneamen- } \\
\text { to Ambiental. }\end{array}$ \\
\hline $\begin{array}{c}\text { Unidades } \\
\text { de } \\
\text { Paisagem }\end{array}$ & Características & Conflitos & $\begin{array}{c}\text { Cenários futuros } \\
\text { possíveis }\end{array}$ & $\begin{array}{c}\text { Cenários futuros } \\
\text { possíveis }\end{array}$ & $\begin{array}{c}\text { Principais } \\
\text { projetos, planos } \\
\text { e ações públicas } \\
\text { já executados }\end{array}$ \\
\hline UP 03 & $\begin{array}{l}\text { - relevo plano; } \\
\text { - constitui-se na } \\
\text { APA da várzea do } \\
\text { rio Tietê; } \\
\text { - área de interesse } \\
\text { ecológico, ambi- } \\
\text { ental e paisagís- } \\
\text { tico; } \\
\text { - meandros e } \\
\text { fragmentos de } \\
\text { mata nativa bem } \\
\text { preservados ao } \\
\text { longo do rio Tietê; } \\
\text { - grande concen- } \\
\text { tração de indús- } \\
\text { trias implantadas } \\
\text { na APA da várzea } \\
\text { do rio Tietê; } \\
\text { - extensas áreas } \\
\text { cobertas por cam- } \\
\text { pos e capoeiras; } \\
\text { - urbanização } \\
\text { incipiente; } \\
\text { - conterá parte do } \\
\text { Rodoanel Leste. }\end{array}$ & $\begin{array}{l}\text { - indústrias con- } \\
\text { centradas na APA } \\
\text { da várzea do rio } \\
\text { Tietê; } \\
\text { - CDP situado na } \\
\text { APA da várzea do } \\
\text { rio Tietê; } \\
\text { - exploração } \\
\text { mineral com con- } \\
\text { cessão de lavra de } \\
\text { argila e lavra de } \\
\text { cascalho; } \\
\text { - implantação de } \\
\text { empreendimentos } \\
\text { vinculados à in- } \\
\text { dústria, na APA da } \\
\text { várzea do rio Tietê } \\
\text { iá licenciados; } \\
\text { - loteamentos } \\
\text { consolidados na } \\
\text { APA da várzea } \\
\text { do rio Tietê, com } \\
\text { graves problemas } \\
\text { de drenagem. }\end{array}$ & $\begin{array}{l}\text { - implantação do } \\
\text { parque Várzeas do } \\
\text { Tietê; } \\
\text { - conexão dos } \\
\text { fragmentos de } \\
\text { matas existentes; } \\
\text { - ampliação das } \\
\text { potencialidades } \\
\text { paisagísticas; } \\
\text { - convivência da } \\
\text { população com } \\
\text { a temática ambi- } \\
\text { ental; } \\
\text { - contemplação } \\
\text { do alto valor } \\
\text { cênico; } \\
\text { - universalização } \\
\text { dos serviços de } \\
\text { água e esgoto } \\
\text { pela Sabesp até } \\
2018 \text {. }\end{array}$ & $\begin{array}{l}\text { - extinção dos } \\
\text { fragmentos de } \\
\text { matas existentes, } \\
\text { devido a ações } \\
\text { antrópicas; } \\
\text { - ampliação da } \\
\text { poluição sanitária } \\
\text { no rio Tietê; } \\
\text { - ampliação da } \\
\text { impermeabilização } \\
\text { do solo a partir } \\
\text { da instalação de } \\
\text { empreendimen- } \\
\text { tos vinculados à } \\
\text { indústria na várzea } \\
\text { do rio Tietê; } \\
\text { - a alça do Ro- } \\
\text { doanel Leste será } \\
\text { implantada na } \\
\text { APA da várzea do } \\
\text { rio Tietê. }\end{array}$ & $\begin{array}{l}\text { - projeto já } \\
\text { elaborado do } \\
\text { parque Várzeas do } \\
\text { Tietê pelo governo } \\
\text { do Estado de São } \\
\text { Paulo; } \\
\text { - desenvolvimento } \\
\text { do Plano Munici- } \\
\text { pal de Saneamen- } \\
\text { to Ambiental. }\end{array}$ \\
\hline
\end{tabular}




\begin{tabular}{|c|c|c|c|c|c|}
\hline UP 04 & $\begin{array}{l}\text { - relevo principal- } \\
\text { mente plano; } \\
\text { - urbanização } \\
\text { consolidada, } \\
\text { com bom padrão } \\
\text { de urbanização } \\
\text { (sistema viário, } \\
\text { iluminação, } \\
\text { saneamento, } \\
\text { espaços livres; } \\
\text { - praças e } \\
\text { parques com usos } \\
\text { definidos; } \\
\text { - equipamentos } \\
\text { urbanos, voltados } \\
\text { à saúde, edu- } \\
\text { cação, cultura; } \\
\text { - áreas destinadas } \\
\text { à indústria; } \\
\text { - áreas de } \\
\text { reflorestamento, } \\
\text { campos, chácaras } \\
\text { e cultivo de horti- } \\
\text { frutigranjeiros; } \\
\text { - conterá parte do } \\
\text { Rodoanel Leste. }\end{array}$ & $\begin{array}{l}\text { - exploração imo- } \\
\text { biliária latente; } \\
\text { - impermeabili- } \\
\text { zação do solo; } \\
\text { - sistema público } \\
\text { de drenagem } \\
\text { deficiente; } \\
\text { - corpos d'água } \\
\text { canalizados; } \\
\text { - constantes } \\
\text { enchentes no pe- } \\
\text { ríodo de chuvas; } \\
\text { - calçadas e ar- } \\
\text { borização urbana } \\
\text { inadequadas; } \\
\text { - polvição visual } \\
\text { nas fachadas dos } \\
\text { comércios. }\end{array}$ & $\begin{array}{l}\text { • implementação } \\
\text { de arborização } \\
\text { urbana adequada; } \\
\text { - implantação de } \\
\text { espécies arbóreas } \\
\text { ao longo dos cór- } \\
\text { regos canalizados } \\
\text { ou não; } \\
\text { - requalificação } \\
\text { de praças exis- } \\
\text { tentes; } \\
\text { - criação de } \\
\text { calçadões; } \\
\text { - implementação } \\
\text { de infraestruturas } \\
\text { verdes; } \\
\text { - requalificação } \\
\text { das calçadas; } \\
\text { - ampliação do } \\
\text { campus da UniPi- } \\
\text { aget e do IFSP; } \\
\text { • universalização } \\
\text { dos serviços de } \\
\text { água e esgoto } \\
\text { pela Sabesp até } \\
2018 .\end{array}$ & $\begin{array}{l}\text { - diminuição das } \\
\text { espécies arbóreas } \\
\text { nas áreas urbani- } \\
\text { zadas; } \\
\text { - dificuldade de } \\
\text { acessibilidade } \\
\text { junto às calçadas; } \\
\text { - ausência de } \\
\text { manutenção das } \\
\text { calçadas. }\end{array}$ & $\begin{array}{l}\text { - planos de } \\
\text { requalificação: } \\
\text { Quadrilátero } \\
\text { Central, Orla Fer- } \\
\text { roviária e Expan- } \\
\text { são do Centro; } \\
\text { - construção de } \\
\text { equipamentos } \\
\text { públicos, tais } \\
\text { como: Terminal } \\
\text { Vereador Diniz } \\
\text { dos Santos Faria, } \\
\text { creches, centro } \\
\text { de cultura, UBSs, } \\
\text { dentre outros; } \\
\text { - construção da } \\
\text { praça Cidade das } \\
\text { Flores; } \\
\text { - reordenamento } \\
\text { do trânsito; } \\
\text { • plano de } \\
\text { limpeza urbana e } \\
\text { visual; } \\
\text { - projeto ciclo- } \\
\text { viário para a ave- } \\
\text { nida João Batista } \\
\text { Fitipaldi; } \\
\text { - construção do } \\
\text { campus da UniPi- } \\
\text { aget; } \\
\text { - construção do } \\
\text { campus do IFSP; } \\
\text { - construção de } \\
\text { vários equipamen- } \\
\text { tos no parque Max } \\
\text { Feffer; } \\
\text { - desenvolvimento } \\
\text { do Plano Munici- } \\
\text { pal de Saneamen- } \\
\text { to Ambiental. }\end{array}$ \\
\hline
\end{tabular}




\begin{tabular}{|c|c|c|c|c|c|}
\hline $\begin{array}{c}\text { Unidades } \\
\text { de } \\
\text { Paisagem }\end{array}$ & Características & Conflitos & $\begin{array}{c}\text { Cenários futuros } \\
\text { possíveis }\end{array}$ & $\begin{array}{l}\text { Cenários futuros } \\
\text { possíveis }\end{array}$ & $\begin{array}{c}\text { Principais } \\
\text { projetos, planos } \\
\text { e ações públicas } \\
\text { já executados }\end{array}$ \\
\hline UP 05 & $\begin{array}{l}\text { - urbanização } \\
\text { consolidada; } \\
\text { - relevo pratica- } \\
\text { mente plano; } \\
\text { - diversas indús- } \\
\text { trias instaladas; } \\
\text { - áreas de } \\
\text { reflorestamento, } \\
\text { matas, capoeiras e } \\
\text { campos; } \\
\text { - áreas de chá- } \\
\text { caras; } \\
\text { - cultivo de horti- } \\
\text { frutigranjeiros; } \\
\text { - considerável } \\
\text { presença de vege- } \\
\text { tação de várzea } \\
\text { junto à represa de } \\
\text { Taiaçupeba. }\end{array}$ & $\begin{array}{l}\text { - indústria junto à } \\
\text { área de várzea do } \\
\text { rio Tietê; } \\
\text { - grande área } \\
\text { de exploração } \\
\text { mineral; } \\
\text { - movimentação } \\
\text { de terra com solo } \\
\text { exposto. }\end{array}$ & $\begin{array}{l}\text { • criação de } \\
\text { infraestrutura vol- } \\
\text { tada ao turismo; } \\
\text { • criação de } \\
\text { parques lineares; } \\
\text { - criação de } \\
\text { corredores } \\
\text { ecológicos; } \\
\text { • potencialização } \\
\text { do alto valor } \\
\text { cênico; } \\
\text { - universalização } \\
\text { dos serviços de } \\
\text { água e esgoto } \\
\text { pela Sabesp até } \\
2018 .\end{array}$ & $\begin{array}{l}\text { - ampliação da } \\
\text { impermeabilização } \\
\text { do solo próximo } \\
\text { à várzea do rio } \\
\text { Tietê; } \\
\text { - expansão e } \\
\text { consolidação } \\
\text { das ocupações } \\
\text { residenciais ir- } \\
\text { regulares. }\end{array}$ & $\begin{array}{l}\text { - construção de } \\
\text { equipamentos } \\
\text { públicos, tais } \\
\text { como: creches, } \\
\text { escolas, centro } \\
\text { cultural, UBSs } \\
\text { dentre outros; } \\
\text { - desenvolvimento } \\
\text { do Plano Munici- } \\
\text { pal de Saneamen- } \\
\text { to Ambiental. }\end{array}$ \\
\hline UP 06 & $\begin{array}{l}\text { - relevo plano nas } \\
\text { áreas ocupadas } \\
\text { e colinoso nos } \\
\text { espaços onde a } \\
\text { maior parte da } \\
\text { vegetação de } \\
\text { mata nativa se } \\
\text { encontra; } \\
\text { - intenso cultivo } \\
\text { de hortifrutigran- } \\
\text { jeiros; } \\
\text { - considerável } \\
\text { reflorestamento; } \\
\text { - área de interesse } \\
\text { ecológico, ambi- } \\
\text { ental e paisagís- } \\
\text { tico; } \\
\text { - diversos frag- } \\
\text { mentos de mata } \\
\text { nativa; } \\
\text { - áreas de campo } \\
\text { e capoeiras; } \\
\text { - pequena quanti- } \\
\text { dade de vege- } \\
\text { tação de várzea } \\
\text { junto à bacia do } \\
\text { rio Guaió; } \\
\text { - poucas áreas de } \\
\text { chácaras; } \\
\text { - urbanização } \\
\text { incipiente; } \\
\text { - praças não } \\
\text { urbanizadas; } \\
\text { - conterá a maior } \\
\text { parte do Rodoanel } \\
\text { Leste. }\end{array}$ & $\begin{array}{l}\text { - movimentação } \\
\text { de terra com solo } \\
\text { exposto; } \\
\text { - desmatamentos } \\
\text { pontuais, caça } \\
\text { ilegal de animais } \\
\text { silvestres; } \\
\text { - grandes áreas } \\
\text { de reflorestamento } \\
\text { impostas entre } \\
\text { os fragmentos de } \\
\text { matas nativas. }\end{array}$ & $\begin{array}{l}\text { - criação de } \\
\text { corredores } \\
\text { ecológicos; } \\
\text { - potencial para } \\
\text { extração vegetal } \\
\text { regular; } \\
\text { • universalização } \\
\text { dos serviços de } \\
\text { água e esgoto } \\
\text { pela Sabesp até } \\
2018 \text {. }\end{array}$ & $\begin{array}{l}\text { - passagem do } \\
\text { Rodoanel Leste; } \\
\text { - expansão e } \\
\text { consolidação } \\
\text { das ocupações } \\
\text { residenciais ir- } \\
\text { regulares }\end{array}$ & $\begin{array}{l}\text { - desenvolvimento } \\
\text { do Plano Munici- } \\
\text { pal de Saneamen- } \\
\text { to Ambiental. }\end{array}$ \\
\hline
\end{tabular}




\begin{tabular}{|c|c|c|c|c|c|}
\hline $\begin{array}{l}\text { Unidades } \\
\text { de } \\
\text { Paisagem }\end{array}$ & Características & Conflitos & $\begin{array}{c}\text { Cenários futuros } \\
\text { possíveis }\end{array}$ & $\begin{array}{c}\text { Cenários futuros } \\
\text { possíveis }\end{array}$ & $\begin{array}{c}\text { Principais } \\
\text { projetos, planos } \\
\text { e ações públicas } \\
\text { já executados }\end{array}$ \\
\hline UP 07 & $\begin{array}{l}\text { - relevo plano e } \\
\text { inclinado; } \\
\text { - grande presença } \\
\text { de chácaras; } \\
\text { - baixa con- } \\
\text { centração de } \\
\text { reflorestamento, } \\
\text { capoeiras e } \\
\text { campos; } \\
\text { - cultivo de horti- } \\
\text { frutigranjeiros; } \\
\text { - proximidade } \\
\text { com a represa de } \\
\text { Taiaçupeba; } \\
\text { - urbanização em } \\
\text { fase de consoli- } \\
\text { dação. }\end{array}$ & $\begin{array}{l}\text { - ampliação } \\
\text { da represa de } \\
\text { Taiaçupeba, que } \\
\text { propiciará a reti- } \\
\text { rada de: espaços } \\
\text { destinados ao cul- } \\
\text { tivo de hortifruti- } \\
\text { granjeiros, além } \\
\text { de matas, campos } \\
\text { e capoeiras; } \\
\text { - movimentação } \\
\text { de terra com solo } \\
\text { exposto. }\end{array}$ & $\begin{array}{l}\text { - instalação de es- } \\
\text { truturas turísticas; } \\
\text { - contemplação } \\
\text { do alto valor } \\
\text { cênico; } \\
\text { - universalização } \\
\text { dos serviços de } \\
\text { água e esgoto } \\
\text { pela Sabesp até } \\
2018 \text {. }\end{array}$ & $\begin{array}{l}\text { - ocupação } \\
\text { urbana, chá- } \\
\text { caras e cultivo de } \\
\text { hortifrutigranjeiros } \\
\text { geram empecilhos } \\
\text { com relação à } \\
\text { implantação das } \\
\text { estruturas turísticas } \\
\text { compatíveis com } \\
\text { este espaço. }\end{array}$ & $\begin{array}{l}\text { - construção de } \\
\text { equipamentos } \\
\text { públicos, tais } \\
\text { como: creches, } \\
\text { escolas e UBSs; } \\
\text { - execução de } \\
\text { infraestrutura } \\
\text { urbana: pavimen- } \\
\text { tação e ilumi- } \\
\text { nação pública; } \\
\text { - desenvolvimento } \\
\text { do Plano Munici- } \\
\text { pal de Saneamen- } \\
\text { to Ambiental. }\end{array}$ \\
\hline UP 08 & $\begin{array}{l}\text { - relevo colinoso; } \\
\text { - área de grande } \\
\text { interesse ecológi- } \\
\text { co, ambiental e } \\
\text { paisagístico; } \\
\text { - intenso reflores- } \\
\text { tamento; } \\
\text { - chácaras recrea- } \\
\text { tivas; } \\
\text { - grandes frag- } \\
\text { mentos de matas } \\
\text { nativas; } \\
\text { - diversas áreas } \\
\text { de capoeiras e } \\
\text { campos; } \\
\text { - cultivo de horti- } \\
\text { frutigranjeiros; } \\
\text { - urbanização } \\
\text { incipiente. }\end{array}$ & $\begin{array}{l}\text { - ocupações } \\
\text { urbanas; } \\
\text { - indústrias; } \\
\text { - exploração } \\
\text { mineral; } \\
\text { - movimentação } \\
\text { de terra com solo } \\
\text { exposto; } \\
\text { - disposição irre- } \\
\text { gular de resíduos } \\
\text { por municípios } \\
\text { vizinhos; } \\
\text { - desmatamentos } \\
\text { pontuais; } \\
\text { - maiores áreas } \\
\text { voltadas ao re- } \\
\text { florestamento de } \\
\text { eucalipto; } \\
\text { - caça ilegal de } \\
\text { animais silvestres. }\end{array}$ & $\begin{array}{l}\text { - maiores pos- } \\
\text { sibilidades com } \\
\text { relação à criação } \\
\text { de corredores } \\
\text { ecológicos; } \\
\text { - potencialização } \\
\text { do valor cênico; } \\
\text { - instalação de } \\
\text { estruturas turístico- } \\
\text {-ecológicas, } \\
\text { junto à represa de } \\
\text { Taiaçupeba; } \\
\text { - extração vegetal } \\
\text { regular; } \\
\text { - potencial para } \\
\text { extração mineral } \\
\text { regular; } \\
\text { - universalização } \\
\text { dos serviços de } \\
\text { água e esgoto } \\
\text { pela Sabesp até } \\
2018 \text {. }\end{array}$ & $\begin{array}{l}\text { - extinção de sig- } \\
\text { nificativos corpos } \\
\text { d'água e fragmen- } \\
\text { tos florestais; } \\
\text { - pressões advin- } \\
\text { das da agricultura; } \\
\text { - pressões advin- } \\
\text { das da exploração } \\
\text { mineral; } \\
\text { - interesse imobi- } \\
\text { liário latente; } \\
\text { - expansão e con- } \\
\text { solidação das ocu- } \\
\text { pações residen- } \\
\text { ciais irregulares, } \\
\text { caracterizadas } \\
\text { como chácaras de } \\
\text { recreio. }\end{array}$ & $\begin{array}{l}\text { - construção de } \\
\text { equipamentos } \\
\text { públicos: tais } \\
\text { como, creches, } \\
\text { escolas e UBSs; } \\
\text { - desenvolvimento } \\
\text { do Plano Munici- } \\
\text { pal de Saneamen- } \\
\text { to Ambiental. }\end{array}$ \\
\hline
\end{tabular}




\begin{tabular}{|c|c|c|c|c|c|}
\hline $\begin{array}{c}\text { Unidades } \\
\text { de } \\
\text { Paisagem }\end{array}$ & Características & Conflitos & $\begin{array}{l}\text { Cenários futuros } \\
\text { possíveis }\end{array}$ & $\begin{array}{l}\text { Cenários futuros } \\
\text { possíveis }\end{array}$ & $\begin{array}{c}\text { Principais } \\
\text { projetos, planos } \\
\text { e ações públicas } \\
\text { já executados }\end{array}$ \\
\hline UP 09 & $\begin{array}{l}\text { - relevo aciden- } \\
\text { tado; } \\
\text { • área de inte- } \\
\text { resses ecológico, } \\
\text { ambiental e } \\
\text { paisagístico; } \\
\text { • presença de } \\
\text { indústrias, chá- } \\
\text { caras, cultivo de } \\
\text { hortifrutigranjeiros, } \\
\text { fragmentos de } \\
\text { mata nativa, cam- } \\
\text { pos e capoeiras; } \\
\text { - urbanização em } \\
\text { fase de consoli- } \\
\text { dação. } \\
\text { • praças pouco } \\
\text { urbanizadas. }\end{array}$ & $\begin{array}{l}\text { - presença de } \\
\text { ocupações urba- } \\
\text { nas; } \\
\text { - desmatamentos } \\
\text { pontuais; } \\
\text { - caça de animais } \\
\text { silvestres; } \\
\text { - indústrias. }\end{array}$ & $\begin{array}{l}\text { - desenvolvimento } \\
\text { de interligações } \\
\text { com os demais } \\
\text { fragmentos de } \\
\text { mata existentes no } \\
\text { entorno; } \\
\text { - criação de } \\
\text { parques lineares } \\
\text { junto à represa de } \\
\text { Taiaçupeba; } \\
\text { - universalização } \\
\text { dos serviços de } \\
\text { água e esgoto } \\
\text { pela Sabesp até } \\
2018 .\end{array}$ & $\begin{array}{l}\text { - expansão e } \\
\text { consolidação } \\
\text { das ocupações } \\
\text { residenciais ir- } \\
\text { regulares; } \\
\text { - extinção de sig- } \\
\text { nificativos corpos } \\
\text { d'água e fragmen- } \\
\text { tos florestais; } \\
\text { - contaminação } \\
\text { dos corpos } \\
\text { d'água. }\end{array}$ & $\begin{array}{l}\text { - construção de } \\
\text { equipamentos } \\
\text { públicos, tais } \\
\text { como: creches, } \\
\text { escolas UBS; } \\
\text { - desenvolvimento } \\
\text { do Plano Munici- } \\
\text { pal de Saneamen- } \\
\text { to Ambiental. }\end{array}$ \\
\hline UP 10 & $\begin{array}{l}\text { - relevo parcial- } \\
\text { mente plano e } \\
\text { colinoso; } \\
\text { - área de inte- } \\
\text { resses paisagís- } \\
\text { tico, ambiental e } \\
\text { ecológico; } \\
\text { - área lindeira à } \\
\text { represa de Taiaçu- } \\
\text { peba; } \\
\text { - contém } \\
\text { inúmeras áreas } \\
\text { voltadas às chá- } \\
\text { caras; } \\
\text { - apresenta a } \\
\text { maior quantidade } \\
\text { com relação ao } \\
\text { cultivo de horti- } \\
\text { frutigranjeiros; } \\
\text { • diversas áreas } \\
\text { de campo, ca- } \\
\text { poeira, fragmentos } \\
\text { de mata nativa } \\
\text { e vegetação de } \\
\text { várzea; } \\
\text { • possui cultivo de } \\
\text { eucalipto; } \\
\text { • urbanização } \\
\text { incipiente. }\end{array}$ & $\begin{array}{l}\text { - ocupações ur- } \\
\text { banas desprovidas } \\
\text { de saneamento; } \\
\text { - agricultura } \\
\text { utilizando intensa- } \\
\text { mente os recursos } \\
\text { hídricos; } \\
\text { - expansão da } \\
\text { represa de Taiaçu- } \\
\text { peba irá gerar } \\
\text { a supressão de } \\
\text { diversos tipos de } \\
\text { vegetação; } \\
\text { - fragmentos de } \\
\text { mata desconecta- } \\
\text { dos em função das } \\
\text { atividades vincula- } \\
\text { das à agricultura; } \\
\text { - desmatamentos } \\
\text { pontuais; } \\
\text { - caça ilegal de } \\
\text { animais silvestres. }\end{array}$ & $\begin{array}{l}\text { - atividades vincu- } \\
\text { ladas ao turismo } \\
\text { - incremento de } \\
\text { atividades voltadas } \\
\text { à pesca; } \\
\text { - valorização da } \\
\text { paisagem dado ao } \\
\text { alto valor cênico; } \\
\text { - implementação } \\
\text { de corredores } \\
\text { ecológicos; } \\
\text { - universalização } \\
\text { dos serviços de } \\
\text { água e esgoto } \\
\text { pela Sabesp até } \\
2018 .\end{array}$ & $\begin{array}{l}\text { - extinção de sig- } \\
\text { nificativos corpos } \\
\text { d'água e fragmen- } \\
\text { tos florestais; } \\
\text { - contaminação } \\
\text { dos corpos } \\
\text { d'água; } \\
\text { - expansão e } \\
\text { consolidação } \\
\text { das ocupações } \\
\text { residenciais ir- } \\
\text { regulares. }\end{array}$ & $\begin{array}{l}\text { - desenvolvimento } \\
\text { do Plano Munici- } \\
\text { pal de Saneamen- } \\
\text { to Ambiental. }\end{array}$ \\
\hline
\end{tabular}

Detalhamento das Unidades de Paisagem.

Criação de Michele de Sá Vieira e Elvis José Vieira.

Fonte: Mapa de Uso e Ocupação do Solo - EMPLASA - 2006. Imagens do Google. Acesso em: dez. 2011. 
Estas unidades apresentam similaridades e contrastes que se definem pelas suas características, detalhadas anteriormente, e que serão expostas de forma agrupada em torno de alguns temas, como relevo, densidade das ocupações, níveis de urbanização, cultivo de hortifrutigranjeiros e de eucalipto, recursos naturais, parques e praças, equipamentos edificados e indústria, objetivando, desta forma, gerar uma síntese das unidades de paisagens.

Unidades estas que se distribuem por relevos planos e inclinados, sendo que a inclinação apresenta-se sutil em determinados momentos e mais agressiva em outros, como nas UP's 01, 06, 07 e 10; plano nas UP's 03, 04 e 05; colinoso nas UP's 08 e 09.

Com isto, observam-se duas unidades de paisagem densamente ocupadas, no caso, as UP's 01 e 04, seguidas das UP's 07 e 09, com diferentes níveis de urbanização. Enquanto as UP's 01 e 04 apresentam urbanização consolidada, as demais estão em fase de urbanização.

Por outro lado, as UP's 03 e 08 possuem urbanização incipiente, pelo fato de estarem completamente, ou em grande parte, protegidas pelas legislações estaduais. As UP's 02, 06 e 10 também possuem urbanização incipiente. Neste caso, em função de serem ocupadas em sua maioria por chácaras e plantações de hortifrutigranjeiros.

As áreas de cultivo hortifrutigranjeiras ocupam grandes extensões junto ao território, principalmente nas UP's 06 e 10, aparecendo também nas UP's 02 e 07. Para além dos hortifrutigranjeiros, o cultivo de eucalipto é bastante presente, em função da Suzano Papel e Celulose situar-se no território, sendo que a maior parte do cultivo concentra-se na UP 08, de forma intermediária na UP 06 e em pequenas porções nas UP's 01 , $02,04,05,07$ e 10.

Quanto às áreas de interesse ambiental, ecológico e paisagístico, que abrigam grandes extensões de matas nativas, campos e capoeiras, estão presentes na UP 03, definida pela APA da várzea do rio Tietê, nas UP's 06, 08 e 10, localizadas de forma parcial e em sua totalidade na APM, e também na UP 02, dado ao fato de possuir parte da serra do Itapety. A UP 09, embora esteja dentro da APM, não possui grandes extensões de mata, em função da alta ocupação estimulada pelo Porto Seco.

No que se refere às demais UP's, embora os recursos ambientais estejam presentes, constituem apenas pequena parcela da quantidade total existente. Ressalta-se ainda que algumas delas, como as UP's $01,02,04$ e 05 , fazem fronteira com a APA, guardando importantes remanescentes de vegetação, como é o caso da UP 01, que contém o parque Mirante do Tietê.

Outros importantes recursos ambientais, como a represa de Taiaçupeba e a várzea do Guaió, estão em diversas UP's. A represa, conformada por ampla várzea, possui em seu entorno as UP's $04,05,07,08$ e 10, sendo que a UP 10 contém a maior fronteira. Por outro lado, a várzea encontra-se totalmente dentro da UP 06.

As praças e os parques estão distribuídos por algumas UP's no território, no entanto, somente a UP 04 contém este tipo de equipamento urbanizado com boa qualidade, ou seja, servida de iluminação, pavimentação, áreas verdes tratadas, atividades de lazer 
e mobiliário urbano. As demais, a exemplo das UP's 01, 02, 06 e 09, encontram-se pouco ou não urbanizadas.

As grandes intervenções voltadas à infraestrutura regional acontecerão principalmente na UP 06, que conterá a maior parte do Rodoanel Leste, dentro de Suzano, gerando grandes modificações na várzea, embora passe também pelas UP's 03 e 04.

Com relação à concentração de indústrias, esta acontece principalmente na UP 05, embora se localize também nas UP's 01, 03, 04, 08 e 09. Os equipamentos públicos, assim como a indústria, têm sua principal concentração em uma UP, no caso, na UP 04, embora também esteja presente em outras, como na 01, 05, 07, 09 e 10.

\section{CONSIDERAÇÕES}

Ao analisarmos as identidades naturais e as criadas em cada unidade de paisagem, percebemos que, embora o território possua lugares magníficos sob o aspecto paisagístico, como a região de Palmeiras, a represa de Taiaçupeba e a APA do Tietê, estas não foram exploradas de forma a valorizar os espaços criados do território, não incentivando, consequentemente, a convivência da população com os recursos naturais.

Embora se entenda que toda e qualquer urbanização traga mudanças ao ambiente original, pode-se afirmar que os padrões convencionais de tecido urbano estabelecidos em Suzano foram altamente incompatíveis com o ambiente e a paisagem natural do município, mediante a destruição quase total ou parcial que provocaram, exigindo assim a reconstrução completa ou parcial do local ${ }^{7}$.

Com isso, a maior parte da população que vive nas áreas urbanizadas de Suzano, como os distritos de Boa Vista e Central, perde o benefício de conviver com a existência da vegetação nativa nas suas áreas de moradia, sendo que esta convivência passa a ser usufruída por apenas uma pequena parcela da sociedade, que vive em Palmeiras.

Ao analisarmos as formas de ocupação dos três distritos, observamos que os assentamentos promovem, constantemente, altos graus de processamento no território, pois para a construção dos arruamentos, dos equipamentos coletivos de efeito cênico, como as praças, das indústrias, do comércio, da habitação e agricultura, faz-se necessário promover drásticas transformações no ambiente ${ }^{8}$. De maneira geral, os loteamentos nos três distritos submeteram a paisagem a um modelo rígido de desenho, o que causou sempre perdas reais dos valores paisagísticos e ambientais do território.

Isto acontece por diversas razões, dentre elas em função do modelo de urbanização ser incompatível com alguns aspectos vinculados ao ambiente, como o relevo, ou seja, a malha urbana acaba sendo implantada de modo tradicional, sendo reticulada ou

MACEDO, S. S. Paisagem, urbanização e litoral: do Éden à cidade. Tese (Livre-Docência) - Faculdade de Arquitetura e Urbanismo, Universidade de São Paulo, São Paulo, 1993. p. 56.

8 AFONSO, C. M. A paisagem da Baixada Santista: urbanização, transformação e conservação. São Paulo: Editora da Universidade de São Paulo, FAPESP, 2006, p. 56. 
curvilínea ${ }^{9}$. Esta incompatibilidade, por sua vez, remete a conflitos que se expressam através de problemas vinculados à drenagem urbana, como as enchentes, dado ao incorreto encaminhamento das águas da chuva, à impermeabilização do solo gerada pela pavimentação das áreas ocupadas próximas aos corpos d’água, além da retirada da vegetação, causando grandes alterações no suporte físico ${ }^{10}$.

Para além das questões vinculadas ao urbanismo, verificam-se, também, conflitos ligados à vegetação, já que, em muitos momentos, o fragmento nativo é ignorado. Ou seja, a mata atlântica é considerada, por vezes, um elemento esteticamente agressivo e incompatível com o padrão de beleza socialmente estabelecido, onde somente algumas espécies são consideradas como "belas". Assim, ela é desprezada na composição dos loteamentos, como se a agressividade das espécies nativas também não pudessem compor a beleza cênica dos espaços. Nota-se, dessa forma, que a vegetação usada no cotidiano é adquirida e criada em viveiros, de acordo com os padrões estéticos dos gestores públicos, arquitetos, paisagistas e da sociedade.

\section{REFERÊNCIAS BIBLIOGRÁFICAS}

AFONSO, Cintia Maria. A paisagem da baixada santista: urbanização, transformação e conservação. São Paulo: Edusp/FAPESP, 2006. 306 p.

BONILHA, Iraúna. O desenho da paisagem à beira-rio e as metamorfoses da várzea do Tietê na cidade de São Paulo. Dissertação (Mestrado em Arquitetura e Urbanismo) - Faculdade de Arquitetura e Urbanismo da Universidade de São Paulo, São Paulo, 2002.

BRASIL. Lei Federal n. 6.938/81, de 31 de agosto de 1981. Dispõe sobre a Política Nacional do Meio Ambiente, seus fins e mecanismo de formulação e aplicação, e dá outras providências, Brasília, 1981. Diário Oficial da União, Brasília, DF, 2 set. 1981.

BRASIL. Resolução Federal CONAMA n. 1, de 23 de janeiro de 1986. Dispõe sobre procedimentos relativos ao Estudo de Impacto Ambiental, Brasília, 1986. Diário Oficial da União. Brasília, DF, 17 fev. 86.

BRASIL. Lei Federal n. 9.985/2000 de 18 julho de 2000. Regulamenta o art. 225, § 1², incisos I, II, III, e VII da Constituição Federal, institui o Sistema Nacional de Unidades de Conservação da Natureza e dá outras providências, Brasília, 2000. Diário Oficial da União, Seção 1, p. 1, Brasília, DF, 19 jul. 2000.

CHRISTOFOLETTI, Antonio. Modelagem de sistemas ambientais. São Paulo: Edgard Blucher, 1999. 236 p. COMITÊ da Bacia Hidrográfica do Alto Tietê. Plano da Bacia do Alto Tietê. Relatório Final. Setembro 2002.

GOOGLE MAPS. Disponível em: <http://www.google.com.br/search?hl=pt- BR\&source=hp\&q=google + maps\&g $\mathrm{bv}=2 \& o q=g o o g l e+$ maps\&aq $=f \& a q i=g 10 \& a q l=\& g s \_s m=12 \& g s \_u p l=1375|4140| 0|6812| 1111110|2| 2|0| 422 \mid 215$ 612-2.2.21610>. Acessos em: 2011 e 2012.

HOUGH, Michel. Naturaleza y ciudad: planificación urbana y processos ecológicos. Barcelona: Gustavo Gili, 1998. 336 p.

Infraestrutura verde. Disponível em: <http://www.urbansystems.com.br/noticias/ler/imoveis-cdhu-promove-oficinasobre-infra-estrutura-verde >. Acesso em: 6 fev. 2012.

LEFF, Enrique. Saber ambiental: sustentabilidade, racionalidade, complexidade e poder. Petrópolis: Vozes, 2001. $343 \mathrm{p}$.

LOUREIRO, Carlos Frederico Bernardo. O movimento ambientalista e o pensamento crítico. Rio de Janeiro: Quartet, 2003. 160 p. 
MACEDO, Silvio Soares. Paisagem, urbanização e litoral: do Éden à cidade. 1993. Tese (Livre-docência) Faculdade de Arquitetura e Urbanismo da Universidade de São Paulo, São Paulo, 1993.

Quadro do paisagismo no Brasil. São Paulo: FAUUSP, 1999. (Coleção Quapá.)

QUEIROGA, Eugenio Fernandes. Os sistemas de espaços livres e a constituição da esfera pública contemporânea no Brasil. São Paulo: FAUUSP, 2011 . (Relatório de Pesquisa-Quapá).

MARTINS, Maria Lúcia Refinetti. Moradia e mananciais, tensão e diálogo na metrópole. São Paulo: FAUUSP/ FAPESP, 2006. 206 p.

MC'HARG, lan L. Proyectar con la naturaleza. Barcelona: Gustavo Gili, 2000. 195 p.

MOLLINGA, Peter P. Water, politics and development: framing a political sociology of water resources management. In: Water Alternatives. v. 1, n. 1, 2008. p. 7-23.

MORSELLO, Carla. Áreas protegidas públicas e privadas: seleção e manejo. São Paulo: Annablume/Fapesp, 2001. 344 p.

PELLEGRINO, Paulo Renato Mesquita. Paisagem e ambiente: um processo de aproximação no setor oeste da macrometrópole de São Paulo. Dissertação (Mestrado em Arquitetura e Urbanismo) - Faculdade de Arquitetura e Urbanismo da Universidade de São Paulo, São Paulo, 1987.

Paisagens temáticas: ambiente virtual. Tese (Doutorado em Arquitetura e Urbanismo) - Faculdade de Arquitetura e Urbanismo da Universidade de São Paulo, São Paulo, 1995.

Pode-se planejar a paisagem? In: Paisagem e ambiente: ensaios. v. 13. São Paulo: FAUUSP, 2000.

PHILIPPI JUNIOR, Arlindo. Saneamento, saúde e ambiente: fundamentos para um desenvolvimento sustentável. Barueri: Manole, 2005.

PREFEITURA MUNICIPAL DE SUZANO. Disponível em: <http://www.suzano.sp.gov.br/CN04/secretarias.asp>. Acesso em: 22 de fev. 2012.

Plano Municipal de Abastecimento de Água e Esgotamento Sanitário. v. 1. Junho, 2008.

Revisão do Plano Diretor de Suzano 2006-2016. Ełapa 4 - Construção do conhecimento sobre a realidade local. v. 1, jan. 2007.

Plano Diretor de Macrodrenagem, 2008.

PROJETO ORLA: Fundamentos para gestão integrada. Brasília: MMA/SQA; Brasília: MP/SPU, 2002.

Manual de gestão. Brasília: MMA/SQA; Brasília: MP/SPU, 2002.

REBOUÇAS, Aldo da C.; BRAGA, Beneidt; TUNDISI, José Galizia. Águas doces do Brasil: capital ecológico, uso e conservação. São Paulo: Escrituras, 1999.

RODRIGUES, Ricardo Ribeiro; LEITÃO FILHO, Hermógenes de Freitas; LIMA, Maria Isabel R. G.; KON, Sérgio. Matas ciliares: conservação e recuperação. 2 ed. São Paulo: Edusp/Fapesp, 2001. 320 p.

SAKATA, Francine Gramacho. Paisagismo urbano: requalificação e criação de imagens. São Paulo: Edusp, 2011. $270 \mathrm{p}$.

SANTOS, Rozely Ferreira dos. Planejamento ambiental: teoria e prática. São Paulo: Oficina de Textos, 2004. $184 \mathrm{p}$.

SÃO PAULO (Estado). Lei Estadual n. 898/75, de 18 de dezembro de 1975. Disciplina o uso de solo para a proteção dos mananciais, cursos e reservatórios de água e demais recursos hídricos de interesse da Região Metropolitana da Grande São Paulo e dá providências correlatas. São Paulo, 1975. Diário Oficial do Estado de São Paulo, ano LXXXV, n. 245, Seção 1, p. 1, São Paulo, 19 dez. 1975.

Lei Estadual n. 1.172/76, de 17 de novembro de 1976. Delimita as áreas de proteção relativas aos mananciais, cursos e reservatórios de água, a que se refere o artigo $2^{\circ}$ da Lei Estadual n. 898, 18 de dezembro de 1975, estabelece normas de restrição do uso do solo em tais áreas e dá providências correlatas. São Paulo, 1976. Diário Oficial do Estado de São Paulo, ano LXXXVI, n. 218, Seção 1, p. 2, São Paulo, 18 nov. 1976.

Lei Estadual n. 5.598/87, de 6 de fevereiro de 1987. Declara Área de Proteção Ambiental regiões urbanas e/ou rurais dos municípios de Salesópolis, Biritiba Mirim, Moji das Cruzes, Suzano, Poá, Itaquaquecetuba, Guarulhos, São Paulo, Osasco, Barueri, Carapicuíba e Santana do Parnaíba. São Paulo, 1987. Diário Oficial do Estado de São Paulo, v. 97, n. 26, Seção 1, p. 2, São Paulo, 7 fev. 1987.

Lei Estadual n. 7663/91, de 30 de dezembro de 1991. Estabelece normas de orientação à Política Estadual de Recursos Hídricos, bem como ao Sistema Integrado de Gerenciamento de Recursos Hídricos. São Paulo, 1991. Diário Oficial do Estado de São Paulo, v. 101, n. 247, Seção 1, p. 2, São Paulo, 31 dez. 1991. 
Lei Estadual n. 9.866/97, de 28 de novembro de 1997. Dispõe sobre diretrizes e normas para a proteção e recuperação das bacias hidrográficas dos mananciais de interesse regional do Estado de São Paulo e dá outras providências. São Paulo, 1997. Diário Oficial do Estado de São Paulo, v. 107, n. 230, Seção 1, p. 1, São Paulo, 29 nov. 1997.

Decreto Estadual n. 43.022/98, de 7 de abril de 1998. Regulamenta dispositivos relativos ao Plano Emergencial de Recuperação dos Mananciais da Região Metropolitana da Grande São Paulo, de que trata a Lei n. 9.866, de 28 de novembro de 1997, que dispõe sobre diretrizes e normas para a proteção e a recuperação dos mananciais de interesse regional do Estado de São Paulo e dá providências correlatas. São Paulo, 1998. Diário Oficial do Estado de São Paulo, v. 108, n. 67, Seção 1, p. 1. São Paulo, 8 abr. 1998.

Lei Estadual n. 12.183/05, de 29 de dezembro de 2005. Dispõe sobre a cobrança pela utilização dos recursos hídricos do domínio do Estado de São Paulo, os procedimentos para fixação dos seus limites, condicionantes e valores e dá outras providências. São Paulo, 2005. Diário Oficial do Estado de São Paulo, v. 115, n. 245, Seção 1, p. 4. São Paulo, 30 dez. 2005.

SECRETARIA ESTADUAL DO MEIO AMBIENTE (SMA). Disponível em: <http://www.ambiente.sp.gov.br/>. Acesso em: 22 de fev. 2012.

SUZANO. Lei Complementar Municipal n. 025/96, de $1^{\circ}$ de março de 1996. Dispõe sobre a divisão do território do município em zonas de uso; regula o parcelamento e a ocupação do solo; dispõe sobre os imóveis e as edificações em gera, e dá outras providências. Suzano, 1996.

TÂNGARI, Vera Regina; ANDRADE, Valci Rubens Oliveira de; SCHLEE, Mônica Bahia. (Orgs.). Sistema de espaços livres, o cotidiano, apropriações e ausências. Rio de Janeiro: Universidade Federal do Rio de Janeiro/PROARQ FAUUFRJ, 2009. 496 p.

VEIGA, José Eli da. Desenvolvimento sustentável: o desafio do século XXI. Rio de Janeiro: Garamond Universitária, 2005. 226 p.

VIEIRA, Michele de Sá. Entre as serras: sistema de espaços livres públicos: uma reflexão para Suzano. 283 f. Dissertação (Mestrado em Paisagem e Ambiente) - Faculdade de Arquitetura e Urbanismo da Universidade de São Paulo, São Paulo, 2012.

\section{REFERÊNCIAS DE MAPAS}

SÃO PAULO (Estado). Áreas de Interesse Ambiental Especial (Secretaria do Estado do Meio Ambiente). São Paulo, 2000.

Sistema Produtor Alto Tietê (Secretaria do Estado do Meio Ambiente). São Paulo, 2000.

Área de Proteção dos Mananciais (Empresa Paulista de Planejamento Metropolitano SA - EMPLASA). São Paulo, 2002.

Plano de Bacia do Alto Tietê (Comitê da Bacia Hidrográfica do Alto Tietê). São Paulo, 2002.

2006.

. Uso e Ocupação do Solo (Empresa Paulista de Planejamento Metropolitano SA - EMPLASA). São Paulo,

Planta Base - Denominação de Loteamentos (Prefeitura Municipal de Suzano). Suzano, 2006.

Aerofotogramétrico (Prefeitura Municipal de Suzano). Suzano, 2008.

. T: 1 / Áreas Verdes, Distritos e Recursos Hídricos (Prefeitura Municipal de Suzano). Suzano, 2008.

T: 2 / Transportes e Linhas de Ônibus (Prefeitura Municipal de Suzano). Suzano, 2008.

T: 3 / Base de imagens aéreas para a delimitação das bacias de estudo - Plano Diretor de Macrodrenagem (Prefeitura Municipal de Suzano). Suzano, 2008.

T: 3 / Cobertura Vegetal e Uso do Solo (Prefeitura Municipal de Suzano). Suzano, 2008.

T: 4 / Restrições Ambientais e Atividades Econômicas (Prefeitura Municipal de Suzano). Suzano, 2008.

T: 5 / Plano Diretor de Macrodrenagem (Prefeitura Municipal de Suzano). Suzano, 2008.

. T: 6 / Turismo (Prefeitura Municipal de Suzano). Suzano, 2008.

T: 13 / Locação de várzeas levantadas via sensoriamento remoto - Plano Diretor de Macrodrenagem (Prefeitura Municipal de Suzano). Suzano, 2008. 


\section{ENTIDADES CONSULTADAS}

Agência Ambiental de Mogi das Cruzes

Comitê da Bacia Hidrográfica do Alto Tietê (CBH-AT)

Prefeitura Municipal de Suzano (PMS)

Companhia de Saneamento Básico do Estado de São Paulo (Sabesp)

Secretaria de Saneamento e Recursos Hídricos (SSRH)

Subcomitê da Bacia Hidrográfica do Alto Tietê Cabeceiras (SCBH-ATC) 